\title{
AN ASSESSMENT OF MORRO BAY RESIDENTS' ATTITUDES TOWARD AND KNOWLEDGE ABOUT TOURISM: SETTING THE FOUNDATION FOR SUSTAINABLE TOURISM DEVELOPMENT
}

\author{
A Thesis \\ Presented to \\ Faculty of California Polytechnic State University, San Luis Obispo \\ In Partial Fulfillment \\ of the Requirements for the Degree \\ Master of Science in Agriculture \\ Department of Recreation, Parks, and Tourism Administration
}

by

Tyson Matthew David Stockton

August 2011 
(C) 2011

Tyson M. D. Stockton

ALL RIGHTS RESERVED 


\section{COMMITTEE MEMBERSHIP}

TITLE: An Assessment of Morro Bay Residents' Attitudes Toward and Knowledge About Tourism: Setting the Foundation for Sustainable Tourism Development

AUTHOR: Tyson Matthew David Stockton

DATE SUBMITTED: August 2011

COMMITTEE CHAIR: Jerusha Greenwood, Assistant Professor

COMMITTEE MEMBER: Bill Hendricks, Professor

COMMITTEE MEMBER: John Walker, Associate Professor 


\begin{abstract}
An Assessment of Morro Bay Residents’ Attitudes Toward and Knowledge About Tourism: Setting the Foundation for Sustainable Tourism Development
\end{abstract}

Tyson M. D. Stockton

The purpose of this study was to explore Morro Bay residents' attitudes toward tourism and knowledge about tourism in the three major tourism impact categories (economic, socio-cultural, and environmental). A mail-back questionnaire was handdelivered during the winter of 2011 to 720 Morro Bay residents. In general, Morro Bay residents had slightly positive attitudes toward tourism in their community. The mean attitude score was 3.27 on a 5-point Likert type scale. The subjects had a relatively low level of tourism knowledge. The mean total indirect tourism knowledge score was 2.98 on a 5-point Likert-type scale. Residents' total direct tourism knowledge score was 0.33 on a scale of zero to one. A multiple regression model was used to test for an association between residents' knowledge about tourism, community attachment, socio-demographic variables, and residents' attitudes toward tourism. The only variables that were associated with residents' attitude toward tourism were: length of residency, interest in learning more about tourism, level of education, household income, subjective tourism knowledge, economic tourism knowledge, and environmental tourism knowledge. The two most significant variables were economic tourism knowledge and environmental tourism knowledge. Future research should test the effectiveness of different methods to increase residents' tourism knowledge. 


\section{ACKNOWLEDGEMENTS}

The author would like to thank, Dr. Jerusha Greenwood, Dr. William Hendricks, and Dr. John Walker for their support and guidance throughout my graduate studies; The Morro Bay Community Promotions Committee for financing the cost of the study; and

John Sorgenfrei at TJA advertising for assistance in selecting the study location and study execution. The author would also like to thank his family, parents Matt and Coby Stockton, and sister Erin Stockton for their never wavering and continued support. 


\section{TABLE OF CONTENTS}

Page

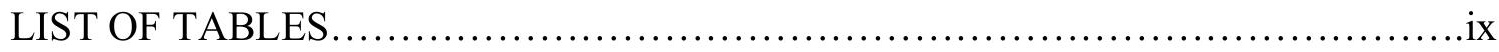

LIST OF FIGURES............................................................

\section{CHAPTER}

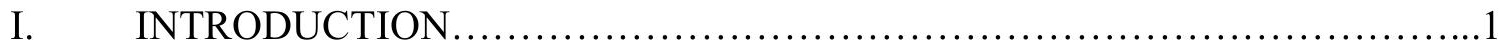

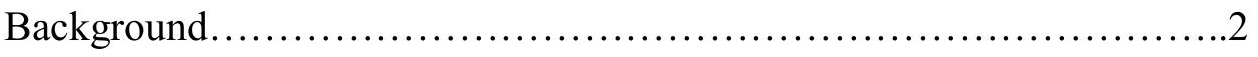

Rationale.......................................................4

Purpose of Study.................................................6

Research Questions...........................................6

Delimitations................................................

Definitions of Key Terms.......................................

Attitude................................................. 8

Community attachment.................................8

Direct knowledge.......................................8

Host community $\ldots \ldots \ldots \ldots \ldots \ldots \ldots \ldots \ldots \ldots \ldots \ldots \ldots \ldots \ldots . \ldots . \ldots \ldots$

Indirect knowledge $\ldots \ldots \ldots \ldots \ldots \ldots \ldots \ldots \ldots \ldots \ldots \ldots \ldots \ldots \ldots$

Sustainable tourism........................................ 8

II. LITERATURE REVIEW ...........................................

Sustainable Tourism Development..............................9

Environmental Sustainability.............................16

Socio-cultural Sustainability............................18

Economic Sustainability..................................20 
Social exchange theory ........................................23

Resident attitudes toward tourism................................27

Level of tourism knowledge...............................33

Level of community attachment............................ 35

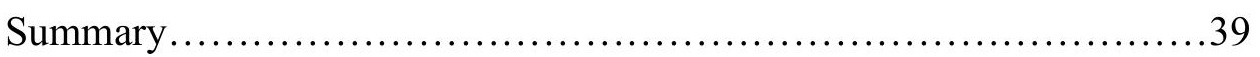

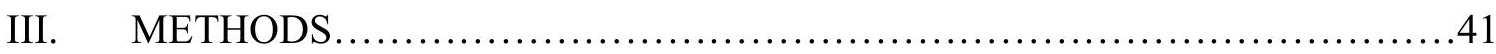

Study Locale................................................41

Description of Subjects.....................................43

Description of Instruments..................................44

Study Procedures............................................51

Data Analysis..............................................55

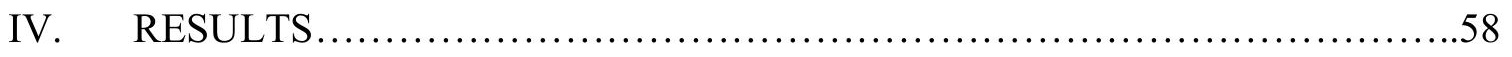

Socio-demographics Profile....................................59

Community Attachment......................................65

Tourism Knowledge.........................................67

Attitudes Toward Tourism.....................................78

Analysis of Research Questions..................................83

V. DISCUSSION..................................................91

Conclusions...............................................91

Practitioner Implications....................................94

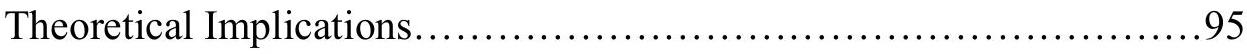

Study Limitations..........................................96

Future Research..............................................97 
APPENDIXES

A. Morro Bay Residents' Attitudes Towards Tourism Survey.................108

B. Cover Letter..................................................... 115

C. Follow-up Cover Letter............................................ 117

D. Informed Consent Forum...........................................119

E. Residuals Versus Predictor Variables..................................121 


\section{LIST OF TABLES}

Table

Page

1. Morro Bay Demographics..........................................42

2. Instrument Variables and Measurement................................49

3. Four Suggested Contacts for Mail Surveys of the Tailored Design Method......53

4. Response Statistics................................................. 58

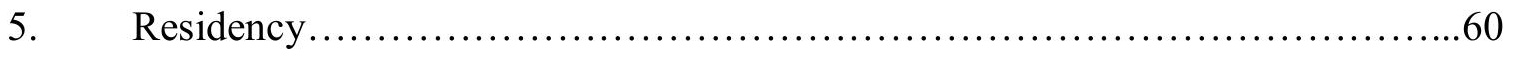

6. Level of Education................................................63

7. Household Income.................................................63

8. Numbers of Visits to the Embarcadero....................................64

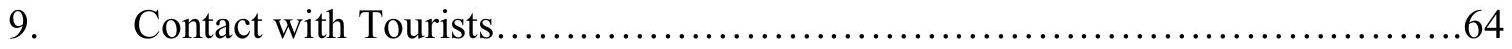

10. Employed by Tourism Industry....................................65

11. Community Attachment...............................................66

12. Indirect Tourism Knowledge........................................68

13. Direct Economic Tourism Knowledge Question One.........................69

14. Direct Economic Tourism Knowledge Question Two.........................70

15. Direct Economic Tourism Knowledge Question Three......................70

16. Direct Socio-Cultural Tourism Knowledge Question One......................72

17. Direct Socio-Cultural Tourism Knowledge Question Two.....................72

18. Direct Socio-Cultural Tourism Knowledge Question Three..................73

19. Direct Environmental Tourism Knowledge Question One.......................75

20. Direct Environmental Tourism Knowledge Question Two......................75

21. Direct Environmental Tourism Knowledge Question Three...................76 
22. Attitudes Toward Tourism........................................... 79

23. Results of General Multiple Regression Analysis...........................84 


\section{LIST OF FIGURES}

Figure

Page

1. Model of Social Exchange Theory....................................26

2. Butler's Tourism Area Cycle of Evolution...............................29

3. Perdue, Long, and Allen's Model of Residents' Tourism Perceptions............30

4. Proposed Conceptual Model.............................................56

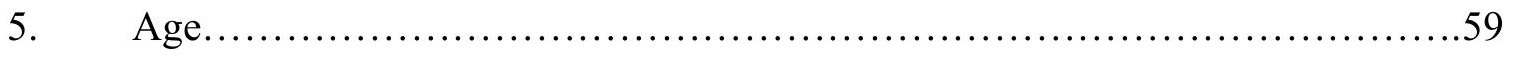

6. Length of Residency ..............................................61

7. Number of Blocks to the Nearest Body of Water............................62

8. Level of Community Attachment....................................67

9. Level of Total Indirect Tourism Knowledge...............................68

10. Level of Direct Economic Tourism Knowledge............................ 71

11. Level of Direct Socio-cultural Tourism Knowledge.........................74

12. Level of Direct Environmental Tourism Knowledge........................77

13. Level of Total Direct Tourism Knowledge.............................. 78

14. Attitude Toward Tourism............................................. 83

15. Residual Plots for General Multiple Regression Model......................87 


\section{CHAPTER 1}

\section{INTRODUCTION}

Tourism has become the largest global industry (Goeldner \& Ritchie, 2006a). Choi and Sirakaya (2006) credit the growth of the tourism industry in the $20^{\text {th }}$ century to the "globalization of capitalism, movement of populations, and advances in transportation and communication technology" (p. 1274). In 2010, the travel and tourism industry was projected to generate a total of $\$ 5,474$ billion toward global gross domestic product and 219,810,000 jobs (World Travel and Tourism Council [WTTC], 2009). Many communities have experienced dwindling traditional industries and have increasingly looked towards tourism to help fill the growing economic void (Andereck \& Vogt, 2000; Latkova, 2008; Perdue, Long, \& Allen, 1987).

The travel and tourism industry has the potential to offer many benefits to these communities. Tourism can improve the quality of life in a host community by increasing employment opportunities, tax revenues, economic diversity, festivals, restaurants, cultural activities, and outdoor recreation opportunities (Andereck, Valentine, Knopf, \& Vogt, 2005). Although tourism can bring many benefits to a host community, it may also cause negative impacts. Tourism "has significantly contributed to environmental degradation, negative social and cultural impacts, and habitat fragmentation" (Choi \& Sirakaya, 2006, p. 1274). Specific negative impacts from tourism may include increased crowding, traffic, crime, cost of living, parking problems, friction between residents and tourists, and changes in residents' way of life (Andereck, et al., 2005; Ap \& Crompton 1993; McCool \& Martin, 1994). To limit the negative impacts while capturing the 
benefits, tourism must be strategically planned and developed. In response to the negative impacts, sustainable tourism has emerged as an alternative form of tourism that aims to limit negative impacts while obtaining the benefits the tourism industry has to offer.

Residents in host communities play a vital role in developing a healthy and prosperous tourism industry (Ap, 1992; Latkova, 2008). There are two important reasons the tourism industry needs the support of host community. First, residents are often asked to vote for tax increases to support infrastructure maintenance and development. Second, a welcoming host community is critical for a successful tourism industry (Gursoy, Jurowski, \& Uysal, 2002). Resident support of tourism has also been identified as an essential element for successful sustainable tourism development (Andereck \& Vogt, 2000; Jurowski \& Gursoy, 2004; Latkova, 2008).

\section{Background}

Morro Bay is located along the central coast of California, approximately 232 miles south of San Francisco and 202 miles north of Los Angeles. Like many other small cities in the United States, Morro Bay has experienced a dwindling local economy. In recent years, two of the major contributors to the local economy, the fishing industry and the Dynergy power plant (also known as the Morro Bay power plant) have decreased their economic contributions. Despite increased demand, the fishing industry in San Luis Obispo County has declined significantly. In 1985, the fishing industry in San Luis Obispo County brought in roughly 15 million pounds of fish, while in 2006 only 1.2 
million pounds of fish were landed (Lisa Wise Consulting, 2008). Lisa Wise Consulting offer the following explanation for the decrease of production in the fishing industry: Reduced access to fish stocks over the past two decades due to intense and often overlapping regulation of the rockfish fisheries, unpredictable and inconsistent markets, the cyclical nature of high-value (salmon, albacore, swordfish) and highvolume species (sardines, squid, mackerel), and declines in over fish stock (2008, p. 1)

Similar to the fishing industry, the Morro Bay power plant has reduced its operations significantly. Currently, only two of the four generating units are operational and are used minimally during the summer months (Coastal Alliance on Plant Expansion [CAPE], 2009). Dynergy pays a tax on the natural gas used to operate the power plant. The power plant's significant decrease in use has also decreased its contribution to local government revenue.

The Morro Bay power plant uses a cooling system called Once-Through Cooling (OTC), which pulls water from the bay to cool the generators then discharges the warm water back into the ocean (CAPE, 2009). Due to new regulations banning OTC along the California coastline, there is talk of the eventual closure of the power. In addition to the tax revenue from the power plant, Morro Bay receives $\$ 750,000$ a year from Dynegy for the lease of land between the power plant and the Morro Rock where the OTC discharge is returned to the ocean. Two hundred and fifty thousand dollars of the lease revenue must be spent on harbor operations and the remaining $\$ 500,000$ goes toward the city's general fund. The current lease expires in 2012, however there is a proposal to extend the lease until 2014, just before the enforcement of the new OTC regulation (CAPE, 2009). 
As a result, the city of Morro Bay wants the tourism industry to play a more significant role in the local economy. Morro Bay has created a tourism business improvement district (TBID) that works in conjunction with five other TBIDs in San Luis Obispo County to increase tourism throughout the county. A promotion committee has also been formed to aid in the tourism development efforts in Morro Bay. The promotion committee has recognized the importance of the community's support, and has allocated funds to create a marketing campaign to increase residents' awareness of the tourism industry.

\section{Rationale}

Residents' attitudes towards tourism have been studied in academic research for over 40 years. Ap and Crompton (1998) concluded that "for tourism to thrive in an area it needs support from the area's residents" (p. 120). It is important that residents have a level of tourism knowledge and positive attitudes toward the tourism industry for the success of a tourism destination. Despite the progress that has been made in understanding residents' attitudes towards tourism, gaps still exist in the literature.

The existing research has identified several predictor variables as significant in examining residents' attitudes toward tourism, such as residents' knowledge of tourism (Andereck et al., 2005; Davis et al., 1988; Lankford \& Howard, 1994; Latkova, 2008). Residents' knowledge of tourism has been measured as indirect knowledge and direct knowledge (Latkova, 2008). Indirect knowledge is the subject's level of perceived knowledge, and can be measured by asking subjects about their knowledge level. For example, "what is your level of tourism knowledge?" Direct tourism knowledge 
measures actual knowledge of specific items, which have a correct answer. For example, how much does tourism contribute to the local economy?

It is largely accepted that there are three tourism impact categories, and these impact categories make up the triple bottom line in sustainable tourism: economic, environmental, and socio-cultural (Swarbrooke, 1999). Residents' knowledge of the tourism industry as a predictor variable has not been previously tested in the form of environmental or socio-cultural direct knowledge. This study contributed to the research on residents' attitudes toward tourism by expanding tourism knowledge as a predictor variable into the three types of tourism impacts.

The city of Morro Bay has decided to execute a marketing campaign to increase residents' awareness of and support for the tourism industry. The goal of tourism development is to increase the quality of life of the residents in a given host community (McCool \& Martin, 1994; Um \& Crompton, 1987). McCool and Martin (1994) state "The overall purpose of tourism development should be to enhance the quality of residents' lives by addressing the economic, social, cultural, recreational, and other benefits of tourism" (p. 29). Results of this study act as a baseline to measure the current residents' attitudes towards tourism in Morro Bay and knowledge of tourism. The findings may aid in the creation of a marketing campaign with a narrower focus. Residents' attitudes toward tourism have not been previously measured in Morro Bay. Therefore, this study may also aid in the planning of future tourism development there. This study will also support Morro Bay's future tourism development plans by establishing a better understanding of the residents' attitudes and knowledge of the tourism industry. 
A marketing campaign to increase residents' awareness of tourism is not a traditional marketing campaign because its central purpose is not focused on increasing revenue. Social marketing has developed as a different paradigm in marketing research, and can be defined as "the adaptation of commercial marketing technologies to programs designed to influence the voluntary behavior to target audiences to improve their personal welfare and that of the society of which they are a part" (Andreasen, 1994, p. 109). If the central goal of tourism development is to increase residents' quality of life, a marketing campaign to increase residents' knowledge and awareness of the tourism industry can be classified as a social marketing campaign. Although, Dinan and Sargeant (2000) noted the increased recognition of using social marketing as a tool in sustainable tourism development, there has been little documented research on using social marketing in sustainable tourism development.

Purpose of Study

The purpose of this study was to explore Morro Bay residents' attitudes toward and knowledge about tourism in the three major tourism impact categories (economic, socio-cultural, environmental).

\section{Research Questions}

1. To what extent is direct economic knowledge of tourism associated with residents' attitudes toward tourism?

2. To what extent is direct socio-cultural knowledge of tourism associated with residents' attitudes toward tourism? 
3. To what extent is direct environmental knowledge of tourism associated with residents' attitudes toward tourism?

4. To what extent is indirect tourism knowledge related to residents' attitudes toward tourism?

5. To what extent is community attachment related to residents' attitudes toward tourism?

6. What relationships exist between residents' attitudes toward tourism and demographic variables?

\section{Delimitations}

This study was conducted within the city limits of Morro Bay, CA. A survey covering residents' attitude toward tourism and knowledge of the tourism was administered during the months of February and March 2011. Survey distributors delivered a questionnaire, cover letter, and pre-paid return envelope to 720 randomly selected residents of Morro Bay. Approximately two to three weeks after the first contact a replacement questionnaire was mailed to the non-respondents. The replacement questionnaire was mailed with a follow-up cover letter, and a pre-stamped return envelope. The follow-ups were hand addressed and mailed with first class postage.

\section{Definition of Key Terms}

The following terms are defined as used in this study. 
Attitude. "Attitudes are intellectual, emotional, and behavioral responses to events, things, and persons which people can learn over time" (Fridgen, 1991, p. 43, as cited by Latkova, 2008).

Community attachment. "The social bond and local sentiment residents express toward their community" (Jurowski, 1998, p. 31)

Direct knowledge. A direct measure of tourism knowledge is an actual measure of an individual's knowledge.

Host community. The community at a tourism destination that hosts the visitors by providing the desired services (Goeldener \& Ritchie, 2006a)

Indirect knowledge. An indirect measure of tourism knowledge is an individuals perceived, self-reported level of knowledge.

Sustainable tourism. "...tourism development that meets the needs of the present without compromising the ability of future generations to meet their own needs...tourism that wisely uses and conserves resources in order to maintain their long-term viability" (Weaver, 2005, p. 10) 


\section{CHAPTER 2}

\section{LITERATURE REVIEW}

The purpose of this chapter is to summarize and evaluate the existing academic literature about residents' attitudes, and the level of tourism knowledge in establishing a sustainable tourism destination. The review of literature is divided into the following topics: sustainable tourism development, social exchange theory, and residents' attitudes toward tourism.

\section{Sustainable Tourism Development}

The following section will provide an overview of sustainable tourism development, starting with a brief history of sustainable development and how sustainable tourism has emerged from this larger construct. Sustainable tourism is then broken down into three key components: economic, environmental, and socio-cultural.

Tourism can be regarded as a more environmentally friendly industry than industries based in resource extraction or manufacturing. However, if not properly planned and managed, tourism may cause lasting negative impacts to a destination (Theobald, 2005). Tourist destinations often rely on the natural and built environment to attract tourists to a destination; as a result the tourism industry has a direct interest in sustainable development (Murphy, 1985; Murphy, \& Price, 2005).

Sustainable development is a relatively modern idea, although the concept can been seen in early examples of city planning, including some towns built by the Romans (Swarbrooke, 1999). Sustainability in its broadest sense means meeting the needs of 
today without compromising the needs of future generations (Swarbrooke, 1999; World Commission on Environment and Development [WCED], 1987). Sustainable development shares similar principles with conservation and stewardship, yet emcompasses a more proactive stance that includes continued economic growth in an environmentally friendly manner (Murphy \& Price, 2005).

Up until the later half of the $19^{\text {th }}$ century, it was believed that natural resources were infinite in supply, thus allowing for the limitless consumption of natural resources. As the consumption rate rapidly increased resources were depleted causing additional natural resources sources to be used. Meadows, Meadows, Randers, and Behrens (1972) developed a formal model investigating five major global concerns "accelerating industrialization, rapid population growth, widespread malnutrition, depletion of nonrenewable resources, and a deteriorating environment" (p. 21). This model looked at the cause, interrelationship, and implications of natural resource consumption in a longterm scale. Meadows et al. (1972) concluded:

1. If the present growth trends in world population, industrialization, pollution food production, and resource depletion continue unchanged, the limits to growth on this planet will be reached sometime within the next one hundred years. The most probable result will be a rather sudden and uncontrollable decline in both population and industrial capacity.

2. It is possible to alter these growth trends and to establish a condition of ecological and economic stability that is sustainable far into the future. The state of global equilibrium could be designed so that the basic material needs 
of each person on earth are satisfied and each person has an equal opportunity to realize his individual human potential.

3. If the world's people decide to strive for this second outcome rather than the first, the sooner they begin working to attain it, the greater will be their chances of success. (Meadows, et al. 1972, p. 23-24)

The five components in this model were characterized as growing exponentially every year. With this expansive growth, it was predicted that within one hundred years physical constraints would be experienced. Meadows et al. (1972) did not produced a step-by-step guide to preventing the physical restraints; rather, the authors established the need to move from an age of growth to an age of equilibrium.

The World Commission on Environment and Development (WCED) was formed in 1987 by the United Nations to create a global agenda for change in regards to sustainable development (WCED, 1987). The Prime Minister of Norway, Gro Harlem Brudtland, led the WCED with the support of a body of scientists, economists, and political leaders. The concept of sustainable development is summarized by the WCED (1987) as,

A process of change in which the exploitation of resources, the direction of investments, the orientation of technological development, and institutional change are all in harmony and enhance both current and future potential to meet human needs and aspirations. (p. 46)

The WCED helped establish a general understanding of sustainable development in the international community and set the foundation for future progress. In 1992, the United Nations Conference on the Environment and Development (UNCED) Earth Summit in 
Rio de Janeiro was held to lay out the framework for implementing sustainable development (Berry \& Ladkin, 1997). A product of the Summit was a comprehensive plan known as Agenda 21, which was adopted by more than 178 countries (UN Department of Economic and Social Affairs, n.d.). During the UNCED Earth Summit, travel and tourism was identified as an industry that had the potential to "make a positive contribution to a healthier planet" (Berry \& Ladkin, 1997, p. 434). In 2002, the World Summit on Sustainable Development (WSSD) was held in Johannesburg, South Africa where the effectiveness of the 1992 Earth Summit was addressed as disappointing, due to the continued increase of global poverty, and environmental exploitation (Murphy \& Price, 2005). However, at the WSSD, Agenda 21 was re-affirmed and strongly supported (UN Department of Economic and Social Affairs, n.d.). Since 1992 there has been progress toward sustainable development, although there is still significant work to be done to ensure long-term prosperity. As the awareness and research of sustainable development have progressed, niche concepts have evolved.

Sustainable tourism development has evolved from the concept of sustainable development, although there are inherent differences between the two concepts (Sharpley, 2000). Sustainable development focuses on sustaining natural resources in the broader sense; whereas, sustainable tourism development emphasizes protecting and sustaining the three core components of tourism and the tourism impacts to the host community.

Sustainable tourism development gained recognition in the global community as awareness of the negative impacts from tourism grew (Swarbrooke, 1999). Recognition of sustainable tourism development has grown to the point where it is largely accepted as 
a desirable objective of tourism development (Sharpley, 2000). Early definitions of sustainable tourism were ambiguous and vague, leaving many researchers and practitioners confused about what the concept actually entailed (Berry \& Ladkin, 1997; Choi \& Sirakaya, 2005; Gunn, 2002; Johnston \& Tyrrell, 2005; Sharpley, 2000). As sustainable tourism has progressed, a more widely accepted definition has been approached, yet complete consensus has not been achieved. Often sustainable tourism is defined by adopting the sustainable development definition termed by the WCED. Swarbrooke (1999) offers an example of such a definition as, "forms of tourism which meet the needs of tourists, the tourism industry, and host communities today without compromising the ability of future generations to meet their own needs" (p. 13). It is critical to establish a working definition of sustainable tourism for the progression of sustainable tourism research and its application in host community's tourism development (Choi \& Sirakaya, 2005; Johnston \& Tyrell 2005; Siegel \& Jakus, 1995).

Some may argue that definitions such as the one previously stated by Swarbrooke (1999) are too vague and do not provide enough direction for practitioners regarding the measurement and maintenance of sustainability efforts. To add even more complexity to the issue, there is great variety in the types of tourism, and tourism impacts to host communities. Many destinations have different concerns and needs for sustainable tourism development. Therefore, a working definition can vary from destination to destination, depending on the needs of the host community. Henderson and Quandt (1971) state, "[G]eneral theories are fruitful because they contain statements which abstract from particulars and find elements which many situations have in common. Increased understanding is realized at the cost of sacrificed detail" (as cited by Johnston, 
and Tyrrell, 2005, p. 124). A sustainable tourism definition must be vague in nature to be applied to the variety of tourist destinations. There is value in a vague definition to increase the understanding of sustainable tourism to the broader population. If a definition is too narrowly focused and cannot be applied to any location, sustainable tourism may be viewed as not relevant and overlooked.

Currently, there appears to be some consensus that sustainable tourism is comprised of three major components: economic, environmental, and socio-cultural. For a destination to develop a sustainable tourism industry it must address each of these elements. These components have been targeted as the major categories of impacts that tourism has on a host community. Some researchers believe a definition of sustainable tourism should contain these elements to ensure each component is addressed in a sustainable tourism development effort. Swarbrooke (1999) offered an additional definition to including these elements, "tourism which is economically viable but does not destroy the resources on which the future of tourism will depend, notably the physical environment and the social fabric of the host community" (p. 13). This definition is openended, so it can be applied to different host communities, yet it offers some additional insight as to what is entailed in a sustainable tourism development plan, by including the elements of the triple bottom line. Similarly, Choi and Sirakaya (2006) suggested a definition that expands the components for some additional detail, "sustainable tourism development should be ecologically responsible, socially compatible, culturally appropriate, politically equitable, technologically supportive and finally economically viable for the host community" (p. 1286). In this definition, the socio-cultural components have been further broken down to help establish particular needs of the 
socio-cultural component. Choi and Sirakaya, in this definition of sustainable tourism also introduced the support of one stakeholder group: the host community. For sustainable tourism to be successful it is necessary to have the support of all the stakeholder groups (Andereck \& Vogt, 2000). A challenge in defining sustainable tourism involves the numerous interest groups included in the tourism industry (Johnston \& Tyrrell, 2005; Swarbrooke). Stakeholder groups will often have different preferences for the outcomes from tourism, resulting in different optimal levels and forms of tourism by the each stakeholder groups (Johnston \& Tyrrell, 2005).

Positive economic impacts often overshadow the other impacts of tourism, especially when a community decides to pursue tourism development to supplement or replace other industries. Yet in conversations about sustainable tourism, the environmental component of the tourism industry is most often discussed. This has left some stakeholders with the misunderstanding that green practices constitute sustainable tourism. For sustainable tourism to be successful, the inter-relationships between all three dimensions must be fully recognized (Swarbrooke, 1999). Since the three dimensions are interrelated, a holistic approach is required for sustainable tourism development (Murphy $\&$ Price, 2005). To gain a more complete understanding of sustainable tourism, one must gain an understanding of the potential environmental, economic, and socio-cultural impacts of tourism.

The following subsections take a closer look at what is included in each component of sustainable tourism. Each component has potential positive and negative impacts. It is important to understand both these impacts to limit the negative impacts while capturing the positive impacts the tourism industry has to offer. 
Environmental sustainability. The natural environment at a destination has a close relationship to the tourism industry. Often it is the environment that attracts tourists, but tourism stakeholders commonly overlook the importance of the local environment when their goal is capturing economic gains (Choi \& Sirakaya, 2005). Therefore, the deterioration of the environment should be the first sign of trouble for a host community (Murphy, 1985). Inskeep (1991) offers a broad definition of the environment as comprising "all the natural and cultural surroundings of people" (p. 339). This offers a great starting point. However, it does not clarify that environment includes both natural and built components (Inskeep, 1991). The environment can be broken down into five components: the natural environment, wildlife, farmed environment, built environment, and natural resources (Swarbrooke, 1999). These different components are not mutually exclusive. Interactions can exists between the different components such as the interaction between a managed forest and wildlife in the area. Due to the relationships between the components, it is beneficial to think of the environment holistically or as an ecosystem (Swarbrooke, 1999).

Tourism can result in both positive and negative impacts on the environment. As more tourists are introduced to a host community, the chances of inducing stress on the local environment increases (Murphy, 1985). Existing literature reveals some contradictory findings of resident perceptions of environmental impacts, unlike sociocultural, and economic impacts that are largely viewed as positive by residents (Andereck, et al. 2005). Negative impacts can include water pollution, air pollution, noise pollution, visual pollution, ecological disruption, and the creation of environmental hazards (Inskeep, 1991). Tourism often develops in beautiful but fragile environments, 
which may be at greater risk for negative impacts (Andereck, et al.). For example, in Waikiki, Hawaii, hotel properties were developed too close to the water, obstructing the natural movement of sand on the beach. As a result, sand is brought in multiple times a year to maintain a consistent waterline (Klupiec, 2001).

Positive environmental impacts may include conservation through financial incentive, and increased awareness of environmental issues (Swarbrooke, 1999). Sometimes tourism can even improve environmental quality by giving incentives to clean-up and create access points to natural attractions (Inskeep, 1991). Swarbrooke indicates that some researchers feel more positive results can be obtained from encouraging good practices, rather than just preventing bad ones.

Due to the vast variety of tourist destinations, there is a large variation in the particular environmental needs to be addressed in a sustainable tourism plan. An important piece of the environmental component is the overall atmosphere, of a destination. Poitras and Getz (2006) analyzed the wine tourism industry in Oliver, BC, Canada, noting the steps needed to establish a sustainable wine tourism destination. One key issue in creating a sustainable wine tourism destination was sustaining the rural culture of Oliver, BC. Wine tourists often seek wine destinations with a rustic country setting. If a wine region completely loses its rural atmosphere one might expect visitation to decline or the tourist attraction must evolve. Therefore, it is essential for a sustainable wine tourism industry to maintain its rural atmosphere. Characteristics such as rural atmosphere might not be easily defined by just one component of sustainable tourism. The rural atmosphere of a destination will also partially fall into the sociocultural component. 
Socio-cultural sustainability. The social aspect of sustainable tourism typically does not receive the same amount of attention as the other aspects of tourism. Sometimes this can be attributed to the fact that socio-cultural impacts usually occur slowly over time and are intangible, although social impacts are usually lasting, and not always correctable (Swarbrooke, 1999). The presence of tourism in a host community will “affect people's habits, daily routines, social lives, beliefs, and values" (Dogan, 1989, p. 217). Similar to the other dimensions of sustainability, the presence of tourism can offer positive as well as negative impacts. The level of positive and negative impacts varies depending on the socio-cultural structure of the host community and the level of tourism development (Dogan).

Dogan (1989) stated that some of the major negative impacts can include a decline in cultural traditions, rise of materialism, increase in crime rates, social conflicts, and crowding. Major draws for tourists are the cultural traditions of the host community. These cultural traditions sometimes motivate tourist to visit third world countries, which are often at the greatest risk for negative socio-cultural impacts. Many academics studying socio-cultural impacts focus on the impacts created from "tourist[s] from the industrial nations on the people of the Third World countries" (Dogan, 1989, p. 217). In some cases, the presence of mass tourism requires host communities to replicate their traditional ceremonies beyond the normal level, creating a loss in authenticity (Dogan, 1989). Similarly the purpose of the reenactment of traditions can change with the presence of tourism. Prior to the presence of tourism, traditions are preformed simply because they are traditions and part of everyday life. After tourism is introduced, "the cultural institutions of the host societies are presented to tourist[s] for economic purposes, 
thereby becoming a commercial activity and losing their authentic meaning and identity" (Dogan, 1989, p. 219). Loss of authenticity is a growing concern in tourism. Tourists are increasingly seeking to learn about and experience cultures different than their own. Tourists desire authentic experiences, but if a host community loses its authenticity, it is only a matter of time until the tourists react and demand declines.

Increased crime rates are a common socio-cultural impact from tourism. Jud (1975) examined the effect of tourism on crime in Mexico and showed that crime rate had a positive relationship with the number of foreign visitors entering the country (as cited by Dogan, 1989). Dogan states "crimes involving theft, larceny, and robbery were directly affected by tourism, while crimes against persons (rape, murder, and assault) were to a lesser degree and indirectly related to tourism" (p. 218). There are different theories to why tourism may increase crime. Some believe it involves resentment toward the tourist and signify growing conflicts between the social groups. Albuquerque and McElroy (1999) presented findings similar to Dogan in their study of crime in Barbados from 1989-1993. Overall tourists' victimization rates were higher than residents, although, residents were more likely to be victimized by violent crimes, and tourists were more likely to be victimized by property crime and robbery (Albuquerque \& McElroy, 1999).

Most research regarding social impacts has focused on the negative impacts, however sustainable tourism must recognize and hopefully foster positive impacts. Some positive impacts include conservation of cultural heritage, renewal of cultural pride, cross-cultural exchange (Inskeep, 1991). Tourism can offer financial incentives to maintain or rejuvenate host community cultures by providing financial compensation for 
reproduction of traditions. A host community's culture is a tremendous resource that can be used to attract and differentiate the community as a tourist destination. Therefore, it is vital to protect and encourage the growth of the community's culture through tourism development.

Economic sustainability. Tourism can bring many economic benefits to host communities, although tourism can also bring economic cost (Swarbrooke, 1999). Potential positive economic impacts of tourism help gain support from various stakeholders. Tourism stakeholders can be attracted by the potential increases in government revenue. The positive economic impacts of tourism are some of the betterknown impacts from tourism by the general public. However, the concept of economic sustainability is not nearly as well known. Some economic benefits include employment, increased income levels, diversification of local economy, increased local government revenue, contributions to the local economy from the multiplier effect, help keeping local business viable, and stimulates inward investment (Andereck, et al., 2005; Swarbrooke, 1999). The tourism industry helps create jobs in a variety of industries beyond tourism, such as construction, and transportation (Klupiec, 2001). Swarbrooke (1999) explains a major issue of economic sustainability is ensuring that what tourists are paying equals the associated cost, or the level of which the tourism industry is subsidized by the public sector.

Economic costs include low paying jobs, the opportunity cost of pursuing tourism development, necessary infrastructure investment, increased cost of living for residents, and an over-reliance on tourism (Andereck, et al., 2005; Swarbrooke, 1999). Many of the jobs created directly from the tourism industry often require little formal education, and 
are relatively low paying (Klupiec, 2001). As the number of tourists visiting a destination increases, the stress on the host community increases as well. For example, more tourists driving on the roads in the community will increase the damage to the roads and require additional maintenance work. Murphy (1985) uses an example from Hawaii in 1968 that identified the following increased cost for every visitor to Hawaii: highways, airports, police protection, fire protection, sewerage, natural resources, and local parks and recreation. The total variable cost per visitor-day was \$0.69 in 1968 (Murphy, 1985).

The multiplier effect is a concept that explains why tourists spending has a greater local economic impact than the original amount spent. Essentially the multiplier effect is the concept that every dollar spent by a tourist while in the host community will turn over several times before leaving the community, thereby, multiplying the impact of currency spent by tourists in a given host community. This increases the number of people that experience the benefits of money spent by tourists, as well as expanding the benefits beyond immediate tourism businesses. When money spent by tourists leave a community it is termed leakage. An example of leakage could be a hotel buying supplies from outside the host community (Swarbrooke, 1999). Minimizing the leakage in the local economy will result in greater economic impacts. Goeldner and Ritchie (2006a) refer to the multiplier effect as the indirect impacts of tourism. "The indirect or multiplier impact comes into play as visitor spending circulates and re-circulates" (Goeldner \& Ritchie, 2006a, p. 396). Goeldner and Ritchie further break the multiplier into income multiplier and employment multiplier. More jobs are created from the tourists spending circulating and re-circulating throughout a host community. As a result, income in the host community will also grow exponentially with tourist spending. Tourist's spending 
circulates within a destination so that the economic benefits are widely distributed throughout a destination.

The tourism industry has seasonal fluctuations; measures can be made to reduce these fluctuations, although, they cannot be eliminated (Goeldner, \& Ritchie, 2006a). Swarbrooke (1999) suggested that the seasonal nature of the tourism industry "lead[s] to the under-use of infrastructure which is economically inefficient or allow[s] over-used resources a period of time during which they can recover before next season" (p. 65). A host community that is overly dependent on the tourism industry often suffers from unemployment problems during the off-season. If tourism decreases a host community that is over reliant on the tourism industry will acutely feel any downturn in tourism spending (Klupiec, 2001). Destinations with several industries contributing toward the local economy will not feel a downturn in the tourism industry as severely, because the other industries offset the impact.

Murphy (1985) classified the economic impacts into cycles: short-term cycles, medium-term cycles, and long-term cycles. An example of a short-term cycle is a summer resort, and how the demand varies depending on the season. Murphy (1985) states "seasonal demand creates considerable economic inefficiency and stress within the industry and local labor force” (p. 80). Medium-term cycles occur over several years. Medium-term cycles can be caused by either gradual events or sudden events (Murphy, 1985). One example presented by Murphy of a sudden event causing a medium-term cycle was the 1980 Mount Helen eruption for the entire Northwestern region. Long-term cycles begin to look similar to a business product life cycle. Butler's tourist area product life cycle is an example of a long-term cycle (Murphy, 1985). Long-term cycles such as 
Butler's (1980) describe the gradual development of a tourist destination then a decline as the destination matures similar to the product life cycle.

\section{Social Exchange Theory}

The following section provides an overview of social exchange theory, which has been the primary theoretical framework used in examining residents' attitudes towards tourism. Social exchange theory can help explain why residents like or dislike tourism in their community and was the theoretical framework used for this study.

Several models and theories have been developed to address attitudes toward tourism development. The majority of research in this area has been concentrated on residents' attitudes toward tourism. Residents are often the largest stakeholder group and have the greatest variation of attitudes. Stakeholder groups are not mutually exclusive; Many business owners are often residents of the host community where their businesses are located. Similarly, government officials may reside in the community they serve. Research on residents' attitudes supports the use of social exchange theory as a theoretical framework to explain the variance in stakeholders' attitudes.

Social exchange theory is a broad sociological theory used to explain the exchange of resources by individuals and groups (Ap, 1992). Some of the major works that have helped to evolve the theory include Homans (1961), Blau (1964), and Emerson (1972). The core premise of social exchange theory is that individuals evaluate exchanges by costs and benefits prior to entering an exchange (Latkova, 2008). Therefore, if an individual perceives greater benefits than costs to an exchange, they will participate in the exchange. 
Social exchange theory has been applied to various other disciplines beyond sociology. Ap (1992) noted some examples of the various applications of social exchange theory as, “...gift giving (Moschetti, 1979), marriage and kinship (Levi-Strauss, 1969), collective bargaining (Lawler \& Bacharach, 1986), organizational behavior and management (Jacobs 1970; 1974), and marketing (Bagozzi 1975; 1979; Houston \& Gassenheimer 1987; Kotler 1972)" (1992, p. 688). Some of the earliest applications of social exchange theory to leisure research were in the early 1980's in outdoor recreation development and satisfaction studies (Ap, 1992).

One of the earliest applications of social exchange theory within tourism research was the studies conducted by Perdue, et al. (1987; 1990). Perdue, et al. (1987) utilized the theory to hypothesize that residents who participate in outdoor recreation activities have negative perceptions of tourism. Perdue et al. found that outdoor recreation participants perceptions and attitudes toward tourism do not vary from non-participants.

Perdue et al. (1990) used social exchange theory to help explain residents' attitudes toward tourism development in 16 rural communities in Colorado. Social exchange theory proved to be a useful tool in explaining the variation of views toward tourism impacts. Perdue et al. found that, "when controlling for personal benefits from tourism development, perceptions of its impact were unrelated to sociodemographic characteristics and support for additional development was positively or negatively related to the perceived positive of negative impacts of tourism" (p. 586).

Ap (1992) further solidified social exchange theory as a theoretical framework for explaining residents' attitudes toward tourism. Social exchange theory was applied to 
help explain residents' attitudes toward tourism from either a positive or negative perspective (Ap, 1992). Ap concluded that social exchange theory:

suggests that when exchange of resources (expressed in terms of power) between residents and tourism is high and balanced, or high for the host actor in an unbalanced relation, tourism impacts are viewed positively by residents. When exchange of resources is low in either the balanced or unbalanced exchange relations, the impact are viewed negatively. (p. 685)

The exchanges of resources are not limited to tangible exchanges, such as currency. Social exchange theory also incorporates the exchange of intangible resources such as exposure to different cultures. This is a strength of social exchange theory because it allows for the investigation of all tourism impacts (economic, environmental, and sociocultural).

Ap (1992) developed a social exchange process model to better understand residents' perceptions of tourism (Figure 1). The three core basic components of this model are need satisfaction, exchange relation, and consequences of exchange. If the actor perceives the consequences of the exchange positive, the actor will likely enter the exchange again. If the actor perceives negative consequences prior to exchange the actor will not enter the exchange. An exchange will not occur if an actor perceives negative consequences from a previous exchange, and the actor will likely not enter a similar exchange again. 


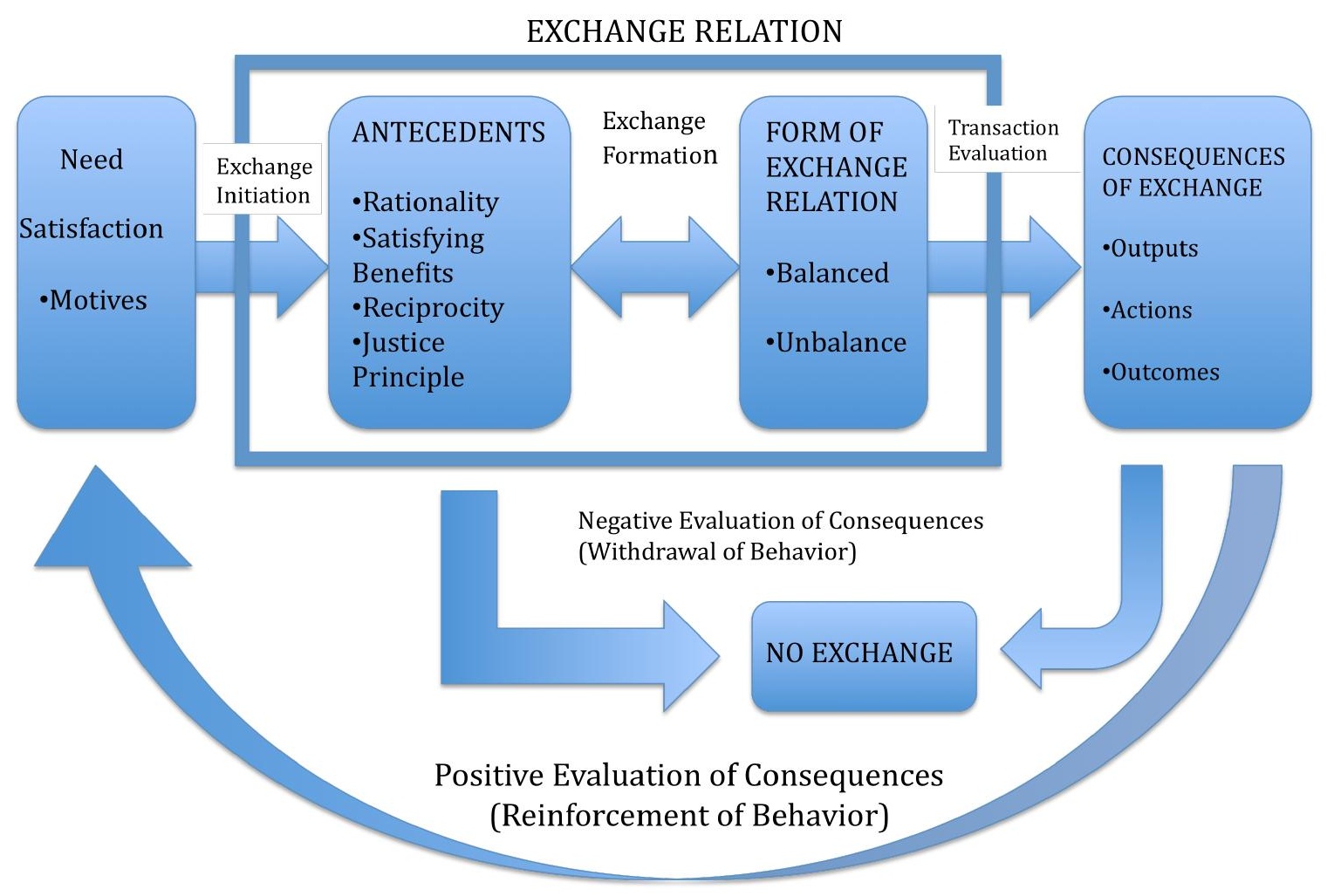

Figure 1: Model of social exchange theory

Source: Ap, 1992 p. 670

Social exchange theory is regarded as the predominant theory for analyzing residents' attitudes toward tourism (Andereck, et al. 2005; Latkova, 2008). The following studies have shown support for the use of social exchange theory in examining resident attitudes toward tourism; Ap (1992), Andereck et al. (2005), Andereck \& Vogt (2000), Andriots \& Vaughan (2003), Choi \& Murray (2010), Gursoy \& Rutherford (2004), Huh \& Vogt (2008), Jurowski \& Gursoy (2004), Kitnuntaviwat \& Tang (2008), Latkova (2008), McGehee \& Andereck (2004), Perdue et al. (1990), Sirakaya, Teye, \& Sonmez (2002), Teye, Sonmez, \& Sirakaya (2002). 
Social exchange theory is also an effective framework for analyzing residents'attitudes toward sustainable tourism development (Kitnuntaviwat \& Tang 2008). Kitnuntaviwat and Tang (2008) explored residents' attitudes towards tourism development and the extent residents were aware of destination sustainability strategies. Kitnuntaviwat and Tang (2008) used social exchange theory as the theoretical framework to examine the relationships between attitudes about sustainability, sense of community, perceived positive impact of tourism, perceived negative impact of tourism, residents' support for tourism attraction development, and residents' support for destination sustainability strategies. Data were collected from 432 residents in Bangkok, Thailand. LISREL (linear structural equations) was used to test for associations. The results indicated association between all variables except sustainable attitudes, and perceived negative tourism impacts. The authors suggested that social exchange theory be used to analyze attitudes toward sustainable tourism development by including additional stakeholder groups beyond residents (Kitnuntaviwat, et al., 2008).

\section{Residents' Attitudes Toward Tourism}

The following section examines the existing literature on residents' attitudes towards tourism. A brief overview of the significant predictor variables that have been identified in academic research is provided with a focus on level of tourism knowledge and level of community support.

Early research on residents' attitudes toward tourism has been primarily exploratory and descriptive in nature (Ap, 1992; Gursoy \& Rutherford, 2004). Doxey's Index of Irritation model (1975) was one of the first models focusing on residents' 
attitudes toward tourism. Doxey's "Irridex" depicts the overall effect of tourism development on residents' attitude toward tourism. As the tourism industry grows and develops in a host community, residents' attitudes toward tourism change. Doxey (1975) presents four stages of resident attitudes: euphoria, apathy, annoyance, and antagonism. The euphoria stage occurs during the early stages of development, when there is little to no tourism planning or marketing. Both tourists and tourism investors are both welcomed by the community. During the apathy stage, there are increases in tourism planning and tourism marketing. At this stage, the relationship between residents and tourists is purely commercial. Next, a host community enters the annoyance stage, which is characterized by the saturation point when tourism demand has been completely developed. Residents begin to feel their needs are being neglected and they begin to question the presence of tourism in the community. The final stage is antagonism, when residents openly express irritation with tourists and the tourism industry.

Similarly, Butler (1980) theorized a tourist area life cycle based upon the product life cycle concept demonstrating the evolution of a tourist destination. The tourist area life cycle shows six stages tourist destinations move through: exploration, involvement, development, consolidation, stagnation, and finally decline or rejuvenation depending on involvement from stakeholders (Figure 2). Butler (1980) shows some of the outcomes toward the end of the life cycle. The life cycle offers insight into tourist type, infrastructure, marketing efforts, and local attitudes toward tourism at each stage of destination development. In order to determine the life cycle stage, Butler uses residents' attitudes as key indicators. The tourist area life cycle is the most discussed, applied, and tested tourism area development model (Latkova, 2008). However, the tourist area life 
cycle model is not perfect. Butler addresses some of the limitations in his study, for instance, not all destinations will move through the cycle the same or go through each stage. An important concept illustrated by Butler's model (1980) is that destinations, if not properly planned and managed, will eventually deteriorate the reason tourist(s) initially visited the host community.

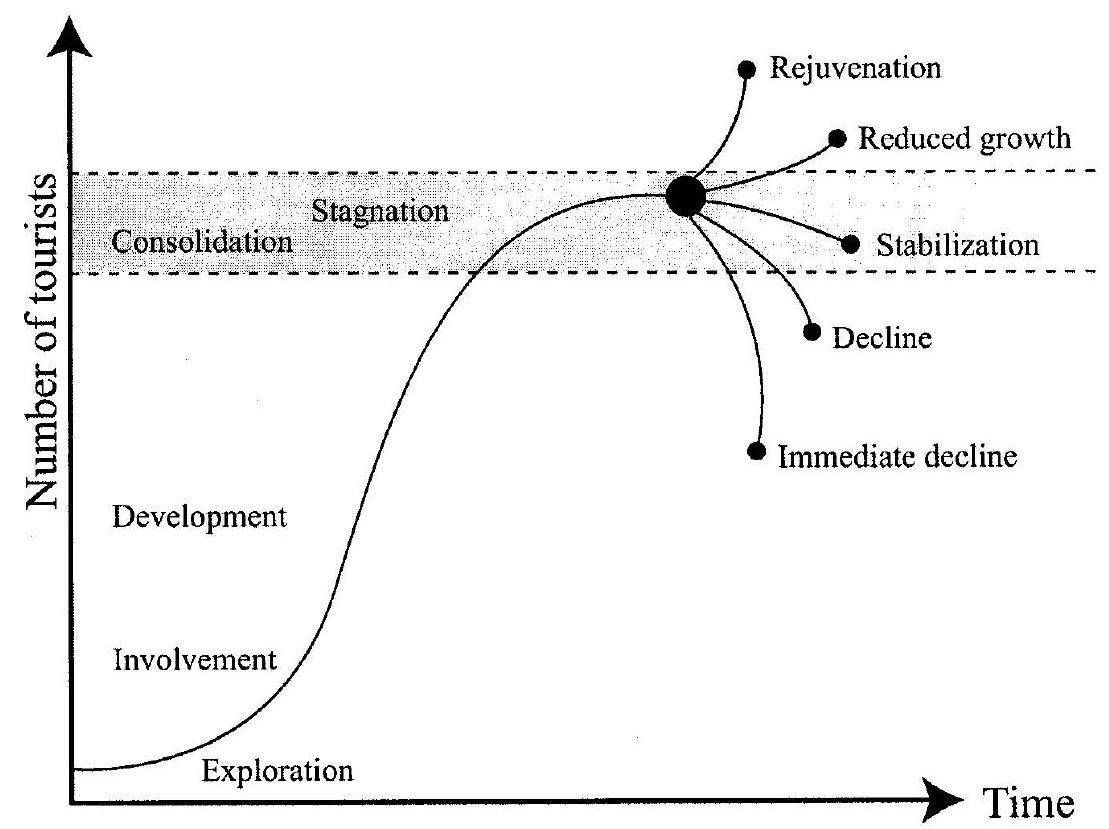

Figure 2: Butler's Tourism Area Cycle of Evolution

Source: Butler, 1980, p. 7

Since 1980, Butlers' tourism area cycle of evolution has been revised and applied to a variety of different locations. Butler (1996) reapplied the tourism area lifecycle concept to the evolution of heritage opportunities in a destination (original use, tourist use, interpretation, restoration, and elaboration). Zimmermann (1997) applied the tourism area lifecycle to several European tourism products: summer recreation, alpine tourism/mountaineering, water-oriented tourism/car, winter sports, city-tours, oversee 
tourism, water-oriented tourism/charter flights. Butler's tourism area cycle (1980) was modified by Agarwal (2006) that added a stage of re-orientation between stagnation subsequent phases.

In the early, 1990s social exchange theory was applied to help explain the variation of residents' attitudes toward tourism development. The application of social exchange theory to research on residents' attitudes has vastly expanded the understanding of why residents perceive tourism impacts to be positive or negative. Perdue et al. (1990) utilized social exchange theory to develop a conceptual model of residents' perceptions of tourism impacts and level of support for tourism development. Since the data collected were from 16 rural Colorado communities, the results were originally limited to rural tourism host communities. In Figure 3, Perdue et al. (1990) model starts with resident characteristics and their perceived personal benefits from tourism development, leading to residents' perception of tourism impacts. If residents have a higher level of perceived personal benefits, then they will likely perceive the impacts from tourism as positive. The residents' perceived impacts of tourism and their perceived future of the community determine the residents' support for additional tourism development.

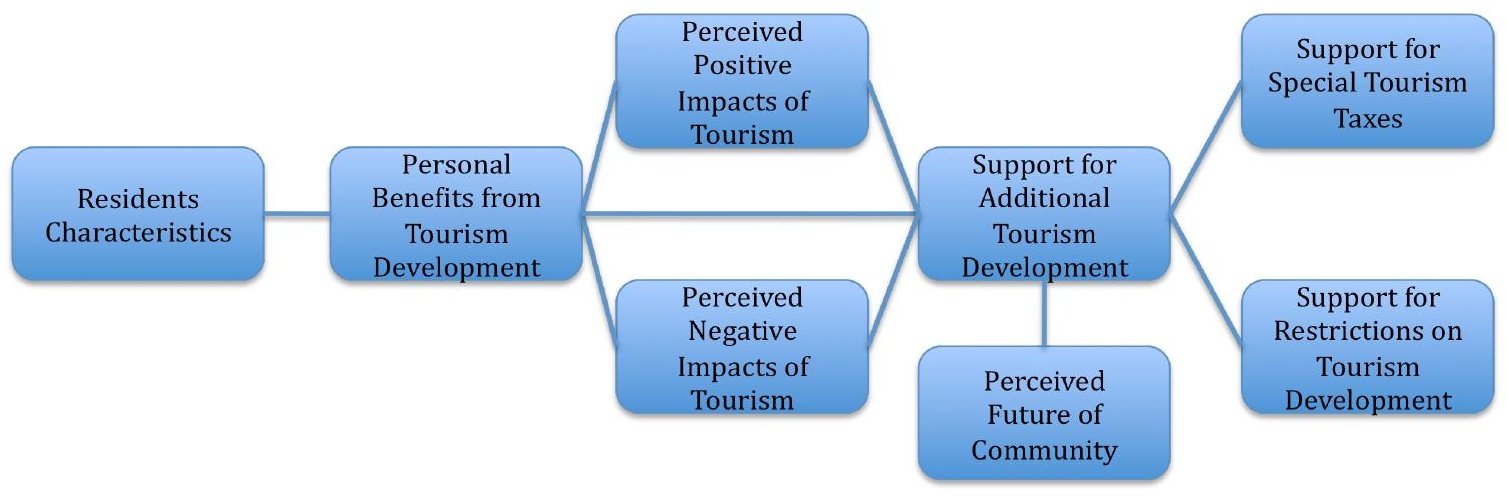

Figure 3: Perdue, Long, and Allen's Model of Residents' Tourism Perceptions

Source: Perdue, Long, and Allen (1990, p. 589). 
This model has been validated and added to by several studies (i.e. Ko \& Stewart, 2002; Latkova, 2008; Madrigal, 1993; McGehee \& Andereck, 2004; Snaith \& Haley, 1994), although the core hypotheses have remained similar. Latkova (2008) added level of knowledge, involvement in decision making (power), community attachment, and economic role of tourism to residents' characteristics.

The Perdue et al., (1990) model contained four main hypotheses. The first hypothesis states that, "even when controlling for personal benefits from tourism development, support for additional tourism development would be positively related to the perceived positive impacts of tourism" along with the inverse for perceived negative impacts (Perdue, et al., 1990, p. 597). This hypothesis was supported by the results of the study, and led to the notion that public relations campaigns aimed at increasing the image of tourism with the host community may be an effective way in increasing local support for tourism (Perdue, et al., 1990). The next hypothesis was also supported: “...support for additional tourism development would be negatively related to the perceived future of the community" (Perdue, et al., 1990, p.597); the worse the economic future looked for the community, the more likely residents would support additional tourism development. The third hypothesis stated that "support for restrictive tourism development policies and special taxes would be negatively related to support for additional tourism development" (Perdue, et al., 1990, p.597). There was no evidence of a relationship between support of special taxes and additional tourism development.

The last hypothesis was “...when controlling for personal benefits from tourism development, tourism impact perceptions would be unrelated to resident characteristics" 
(Perdue, et al., 1990, p. 597). The results generally showed support of this hypothesis. Resident characteristics can include, age, gender, education, income, and length of residence. Subsequent studies produced some contradictory results (Latkova, 2008). McGehee and Andereck (2004) noted that for the most part their findings were consistent with Perdue, et al., (1990), although McGehee, et al. (2004) found evidence for two exceptions: age, and length of residence. The Perdue, et al. (1990) model, however, did not include length of residence as a variable. A possible explanation for the relationship between age and perception of tourism impacts may be that older residents have more opportunities for higher paying employment opportunities from tourism (McGehee, et al., 2004).

There have been several additional factors identified as influencing residents' attitudes toward tourism. Not all variables have experienced unanimous support, however due to the great variation in types of tourism and host communities this may be expected. Some of the variables that have been shown to have a relationship with residents' attitudes include: age (Brougham \& Butler, 1981; Cavus \& Tanrisevdi, 2003; McGehee \& Andereck, 2004; Snaith \& Haley, 1994; Tomljenovic \& Faulkner 2000), education (Iroegbu \& Chen, 2001), gender (Harrill \& Potts, 2003; Mason \& Cheyne, 2000), income (Snaith \& Haley, 1994), community attachment (Brougham \& Butler, 1981; McCool \& Martin, 1994; Lankford \& Howard, 1994; Snaith \& Haley, 1994; Um \& Crompton, 1987), contact with tourist (Andereck, et al., 2005; Brougham \& Butler, 1981), distance from tourism zone (Belisle \& Hoy, 1980; Harrill \& Potts, 2003; Jurowski \& Gursoy, 2004; Snaith \& Haley, 1994), economic role of tourism (Andereck, et al., 2005; Huh \& Vogt, 2008), economic reliance on tourism (Madrigal, 1993; McGehee \& Andereck, 
2004), involvement in decision making (Kayat, 2002; Madrigal, 1993), knowledge about tourism (Andereck, et al., 2005; Davis, et al. 1988; Lankford \& Howard, 1994), level of tourism development (Allen, et al., 1988; Long et al., 1990), length of residence (McGehee \& Andereck, 2004), and personal benefits from tourism (Andereck, et al., 2005; McGehee \& Andereck, 2004; Perdue et al., 1990). For the purposes of this study, the focus is on level of knowledge and community attachment. Therefore, the following sections will examine residents' knowledge about tourism and level of community attachment.

Level of tourism knowledge. Residents' knowledge of tourism has been shown by several studies (i.e. Andereck et al., 2005; Davis et al., 1988; Lankford, 1994; Latkova, 2008) to be a predictor of residents' attitudes. Davis et al. (1988) used knowledge of tourism as a predictor for perceptions of tourism impacts. Davis et al. conducted a survey of 415 Florida residents to create segment groups of the residents based on their attitudes toward tourism. Five segment groups were discovered: haters, lovers, cautious romantics, in-betweeners, and love'em for a reason. Davis et al. (1988) used five questions to assess general knowledge about the tourism industry. The five questions cover "tourist-generated revenues, taxes, employment, total advertising expenditures by the state and the existence of tourism-related associations that are concerned about important issues to Floridians" (Davis et al., 1988, p. 3). The analysis of residents' attitudes toward tourism suggested a strong positive relationship between knowledge of tourism's economic impacts and positive attitude toward the tourism industry. As a result, Davis et al. (1988) concluded that "the more residents know about the tourism industry, the less negative they seem towards it" (p. 7). An implication of these finding is 
that the public should be educated about the positive impacts of tourism on them and their community (Davis et al., 1988). In this study the variable is referred to as knowledge of tourism. However, it is important to note that knowledge was measured primarily on knowledge of economic impacts of tourism, and not environmental or sociocultural.

Lankford et al. (1994) developed the tourism impact attitude scale (TIAS) to establish a standardized measurement of resident attitudes toward tourism development. The TIAS consisted of several independent variables (i.e. length of residence, economic dependency on tourism, distance of tourism center from the respondent's home, resident involvement, birth place, level of knowledge, level of contact with tourists, demographic characteristics, perceived impacts on local outdoor reaction opportunities, rate of community growth) that had been previously shown to influence residents' attitudes toward tourism development. Lankford et al.'s (1994) study took place in the Pacific Northwest, in particular the Columbia River Gorge regions of Washington and Oregon. Knowledge was measured by a question asking the resident what their level of tourism knowledge was, which is a measure of indirect tourism knowledge. From the results of the study, Lankford et al. (1994) determined that "Educational programs, public meetings, and workshops can be undertaken at the local level to help residents understand the tourism industry and its impacts" (p.135).

Andereck et al. (2005) conducted a statewide survey for Arizona that showed a relationship between perceived knowledge and attitudes toward tourism. In particular, Andereck et al. (2005) concluded that people who were more knowledgeable and those with more contact with tourists show a significant relationship with positive perceptions 
of the impacts from tourism on community life, image, and economy, although, this relationship was not supported in regards to community environment, services, or problems. The results showed that the respondents had an awareness that the tourism industry can create positive and negative impacts to different parts of the community, however respondents with higher levels of tourism knowledge were more aware of the positive economic impacts, and other impacts to community life, and image (Andereck, et al., 2005). These findings were consistent with the previous findings of Davis et al. (1988), and Lankford et al. (1994) (as cited in Andereck, et al., 2005).

Latkova (2008) applied level of knowledge along with involvement in decisionmaking (power), community attachment, and economic role of tourism to the model developed by Perdue et al. (1990). This study focused on several rural communities in Michigan that were at different stages of tourism development. Latkova measured both indirect and direct tourism knowledge. Direct knowledge was measured by asking what contribution tourism and recreation had on the county's economy. Indirect knowledge was measured by asking the respondents about their level of tourism knowledge. Latkova (2008) gained a better understanding of resident knowledge by combining direct knowledge with indirect knowledge; however, direct knowledge was still only measuring knowledge of the economic benefits. There could be a difference between residents with high levels of knowledge of tourism's economic impacts than residents with high levels of knowledge of tourism's overall impacts. Latkova (2008) determined that knowledge was significant in examining perceived positive and negative impacts of tourism.

Level of community attachment. McCool and Martin (1994) noted the long history of research on communities, urbanization, and community attachment by Toennies 
(1887), Wirth (1938), and Sampson (1988) showing that "the sense of belonging felt be the residents of a community is an important component of residents' quality of life" ( $p$. 29). Since increasing residents' quality of life is a core goal of tourism development there is a natural interest in community attachment by tourism researchers. Community attachment has been identified as a significant variable in predicting residents' attitudes toward tourism. Studies examining residents' attitudes towards tourism have primarily measured community attachment as length of residence and/or growing up in the community (Latkova, 2008). Residents' with higher levels of community attachment typically do not view the impacts of tourism as positive as residents with lower levels of community attachment (Brougham \& Butler, 1981; Lankford, 1994).

Brougham and Butler (1981) examined community attachment and residents' attitudes. Brougham and Butler (1981) conducted their research in the Sleat peninsula in the United Kingdom during the months of March and June 1976. Brougham and Butler (1981) used segmentation analysis with length of residence as one of the variables in this residents' attitudes study. Length of residency was not directly measured as community attachment in this study; although, Brougham and Butler (1981) is often referenced in support of using community attachment as a predictor variable (Lankford \& Howard, 1994; Latkova, 2008; Um \& Crompton, 1987). The primary conclusion drawn from Brougham et al. (1981) was that tourism does not "constitute a universally beneficial tool for regional development and that all residents should have positive attitudes towards tourism" (p. 586). Length of residence was one variable in the study that supported this conclusion. In particular, residents with longer residency did not view the impacts of tourism as positive as residents with shorter residence (Brougham and Butler, 1981). 
Similarly, Lankford and Howard (1994) used length of residency as a predictor variable for residents' attitudes toward tourism. Lankford and Howard's (1994) results confirmed the finding of Brougham and Butler (1981) that as resident lives in a community longer, the views toward tourism become more negative.

Um and Crompton (1987) identified that length of stay and community attachment may differ. Um and Crompton's (1987) study was an exploratory study that aimed to develop a Guttman scale to measure residents' attachment level and to determine if such a scale would be useful in differentiating residents' perceptions of tourism impacts. Um and Crompton (1987) described the Guttman scales as "a cumulative scale used to determine whether a set of variables measures a single concept and thus whether they can be combined and used as an aggregate measure" (p. 28). The three variables used in the study to measure community attachment were: birthplace, length of stay, and heritage. Um and Crompton's (1987) method of measuring community attachment offers some additional insight; however, it is possible that a new resident, who was not born in the area could have a high level of perceived attachment to the community but, according to Um and Crompton's (1987) measurement, they would appear to have a lower level of attachment. McCool and Martin (1994) presented how methods such as those just described may not be necessarily appropriate by an example of "people moving to a rural community may have searched for specific positive attributes (such as friendliness or lack or crime) and therefore quickly establish interpersonal networks and become highly attached to the community" (p. 30).

In 1994, McCool and Martin measured community attachment in two ways: length of stay and Likert-type scale items adopted from previous studies of community 
attachment: such as, "If I had to move away from my community, I would be very sorry to leave," and "I'd rather live in the town where I live now than anywhere else," (McCool $\&$ Martin, 1994, p. 30). It was determined that more attached respondents rated the positive dimensions of tourism higher than unattached respondents, and the less attached respondents were not as concerned with the cost and impacts of tourism. McCool and Martin compared the results of the Likert-type scale items and length of residence to determine that the longer a resident lives in a community the higher the level of community attachment. However, $\mathrm{McCool}$ and Martin also noted that when using just length of residence there was no detectible difference between newcomers and old timers on positive benefits or negative impacts. However, because length of residency correlates to community attachment there may still be benefits to using community attachment items to assess to residents' attitudes toward tourism, because of the potential for new residents have a high level of community attachment.

Previous research has suggested that sense of community may be a more appropriate measure than community attachment in regards to residents' attitudes toward tourism (Kitnuntaviwat, \& Tang, 2008). Kitnuntaviwat and Tang conducted a study in Bangkok, Thailand examining residents' perceptions and support of sustainable tourism development. This study supported both hypotheses concerning sense of community: "sense of community is positively related to perceived positive impact of tourism" and "sense of community is negatively related to perceived negative impact of tourism" (Kitnuntaviwat et al., p. 58).

Latkova (2008) is another example of an adaptation of community attachment measurements previously utilized in sociology. Latkova adopted community attachment 
items generate by Brehm, Eisenhauer, and Kramich (2004). Brehm et al. measured community attachment by asking the respondents how important a series of items (such as family ties, friends close by, local culture and traditions, and opportunities to be involved in community projects) are to them. This use of community attachment captures two dimensions of the concept: social and environmental (Latkova). Latkova examined residents' attitudes toward tourism in three counties in Michigan. In two of the three counties, Latkova determined that highly attached respondents perceived tourism as positive, which was inconsistent with other studies (Lankford, \& Howard, 1994; McCool $\&$ Martin, 1994). Latkova offered a possible explanation of the variation to be due to "the economic hardships experienced by rural communities, residences with a strong sense of community tend to be more concerned about their communities' future while recognizing the potential of tourism to diversify their declining economy" (p. 141). It was also suggested that in the communities studied community attachment may be more related to their rural lifestyle and the landscape that has developed over time (Latkova).

\section{Summary}

This chapter provides an overview of the evolution of sustainable tourism, starting with sustainable tourism's origins in sustainable development. Sustainable development was theorized to increase the understanding of natural resources are limitations. Meadows et al. (1972) demonstrated that at the rate of natural resource consumption and population growth, the earth's resources would be depleted.

Sustainable tourism has three components: economic, socio-cultural, and environmental. To successfully develop a sustainable tourism destination, all three of 
these components must be addressed. Residents of a host community are a vital part of successful sustainable tourism development.

The primary theoretical framework that has been utilized in studying residents' attitudes has been social exchange theory (Latkova, 2008). Resident attitudes' towards tourism have been studied for over 40 years, with some of the significant early works emerging in the early 1980s, such as Butler (1980), and Murphy (1985). Several predictor variables have been identified as significant in examining residents' attitudes toward tourism, including community attachment, level of tourism knowledge, contact with tourist, and distance to tourists destinations. Residents' knowledge of the tourism industry was identified as a significant predictor variable in examining residents' attitudes (Andereck et al., 2005; Davis et al., 1988; Lankford \& Howard, 1994; Latkova, 2008), although knowledge has not been measured specifically as environmental, economic or social.

Morro Bay, California, like many rural communities in the United States is seeking to expand its tourism services and products due to dwindling traditional industries in that community. In the case of Morro Bay, it is to fill the void created by a shrinking fishing industry, and decreased use and potential closing of the Morro Bay Power Plant. Residents' attitudes toward tourism have not been previously studied in Morro Bay. Therefore, this study will aid in the future development of tourism in the community and help identify the areas of concern that may need to be addressed. The following chapter will present the methodology used to conduct this study. 


\section{CHAPTER 3}

\section{METHODOLOGY}

Residents of a tourist destination play a vital role in the success of sustainable tourism development planning. By measuring Morro Bay residents' attitude toward and knowledge about tourism, this study will provide a baseline for future tourism planning in Morro Bay. The following chapter contains the methods used to conduct this study. This chapter is composed of the following sections: study locale, description of subjects, description of instrument, study procedures and data analysis.

\section{Study Locale}

Residents' attitudes toward tourism were explored in Morro Bay, CA between February and April 2011. Morro Bay is located along the central coast of California, approximately 232 miles south of San Francisco and 202 miles north of Los Angeles. For the last 30 years, the Morro Bay Power Plant, fishing industry, and tourism industry have been the primary contributors to Morro Bay's economy. In recent years, there has been a significant decline in the economic contributions from the power plant and fishing industry. As a result, Morro Bay has been looking at tourism to play a larger role in its local economy. Morro Bay is currently working on further developing its tourism industry. Table 1 (p. 42) is a description of Morro Bay demographics: 
Table 1: Morro Bay Demographics

\begin{tabular}{|c|c|c|}
\hline Demographics & Frequency & Percentage $(\%)$ \\
\hline Total population & 10,350 & 100.00 \\
\hline Male & 4,941 & 47.74 \\
\hline Female & 5,409 & 52.26 \\
\hline 18 years and older & 8,784 & 84.87 \\
\hline 25 years and older & 7,911 & 76.43 \\
\hline English only language spoken at home & 8,810 & 85.12 \\
\hline Speak English less than "very well" & 553 & 5.34 \\
\hline Median age & 45.7 years & \\
\hline Average family size & 2.65 & \\
\hline Average household size & 2.04 & \\
\hline Housing units & 6,251 & 100.00 \\
\hline Occupied hosing units & 4,986 & 79.76 \\
\hline Owner occupied & 2,770 & 44.31 \\
\hline Renter occupied & 2,216 & 35.45 \\
\hline $\begin{array}{l}\text { Vacant housing for seasonal } \\
\text { recreational or occasional use }\end{array}$ & 980 & 15.68 \\
\hline Median household income & $\$ 34,379.00$ & \\
\hline
\end{tabular}

Source: U.S. Census Bureau 2000

The tourism industry in Morro Bay is composed primarily of domestic tourists, with the majority of tourists coming from within California. The three major markets of 
Morro Bay's tourism industry consist of the San Francisco Bay Area, Los Angeles Area, and the California Central Valley. There has been a recent shift in the location of Morro Bay website users in 2010. Previously, the majority of users were located in the Central Valley, although, at the time of this study most site users were located in the Los Angeles Area, followed by the San Francisco Bay Area, and then the Central Valley. One possible explanation for the shift is that tourists from the Central Valley visit Morro Bay for day trips rather than overnight, therefore require less planning. The tourism industry is not a new industry to Morro Bay. However, due to the decreasing economic contributions from other industries there has been an increase in interest and marketing efforts to promote tourism in Morro Bay.

\section{Description of Subjects}

The population for this study was permanent resident homeowners in Morro Bay, CA. Similar studies on residents' attitudes toward tourism have used homeowners as their study population (Latkova, 2008). The sampling frame consisted of residents listed as the owners and occupants of the residence from Fidelity National Title, a local property title company in Fall 2010. The sample excluded renters, vacations rentals, and vacation homeowners. These two populations were expected to have different attitudes towards tourism in Morro Bay and including them in the study sample could potentially skew the results. It was determined that the exclusion of vacation rentals and vacationing homeowners improved study validity.

A sample of approximately 400 was deemed necessary to give reasonably small sampling variability. To be representative of the population, the sampled households 
were selected randomly. Previous research on residents' attitudes toward tourism using Dillman's Total Design method (Dillman, 2007) for data collection ranged in response rates from 27\% (Latkova, 2008), 42\% (Jurowshki, Uysal, Williams, 1997), and 58\% (Choi \& Sirakaya, 2005). Based on the response rates of similar studies, a $40 \%$ response rate was assumed and an initial sample of 1,000 was drawn to reach the goal of 400 completed questionnaires.

\section{Description of Instrument}

The instrument used was a self-administered questionnaire (Appendix A) and was accompanied by a cover letter. Surveys have proven to be valid instruments for measuring attitudes (Babbie, 1998). Some weaknesses of surveys can included low response rates, potentially high cost, and lack of interaction with respondents (Alreck \& Settle, 2004 as cited by Latkova, 2008). The instrument used was composed of four sections; attitudes toward tourism, knowledge of tourism, community attachment and demographics. Table 2 on page 45 shows a break down of the items included in the study instrument.

The first component of the questionnaire was adopted from Lankford and Howard (1994) and has been commonly referred to as the Tourism Impact Attitude Scale (TIAS). Lankford and Howard (1994) originally validated the TIAS instrument in a study on the Colombia Gorge in Washington and Oregon. Since 1994, TIAS has been tested and used in several locations around the world. TIAS was developed to be a standardized measurement of residents' attitudes toward tourism development. Lankford and Howard (1994) combined several independent variables that had been identified as significant to 
residents' attitudes toward tourism and combined them to create TIAS. The attitude portion of the TIAS was adopted and used as the response variable for this study, to see if there is a relationship with the other variables tested. The proceeding components of the instrument were used as independent variables.

Community attachment has been used as a predictor variable to examine residents' attitudes toward tourism. As discussed in Chapter 2, community attachment has been measured in a variety of ways. For the purposes of this study the measurement methods developed by McCool and Martin (1994) were used to measure community attachment. McCool and Martin (1994) developed their measurement from a sociological paradigm and used a series of statements such as "If I had to move away from my community, I would be very sorry to leave," and "I'd rather live in the town where I live now than anywhere else" (p. 30). Respondents were asked to select one of five positions on a Likert-type scale from "strongly agree" to "strongly disagree". The measurement of community attachment for this study was modified from McCool and Martin (1994) to statements specific to Morro Bay. The statements used included "I feel a lot of coastal communities could substitute for Morro Bay," "I have a lot of fond memories of past experiences with family and friends in Morro Bay," "I feel a strong emotional bond to Morro Bay," "I feel a strong sense of belonging in Morro," "There are few satisfactory alternate communities to live at compared to Morro Bay."

The next component of the instrument was used to measure the respondents' level of tourism knowledge. Residents' knowledge of tourism has been identified as a significant variable in examining residents' attitudes toward tourism (Andereck et al., 2005; Davis et al., 1988; Lankford \& Howard, 1994; Latkova, 2008). Tourism knowledge 
has been measured using both indirect tourism knowledge (Andereck et al. 2005;

Lankford and Howard, 1994; Latkova, 2008) and direct tourism knowledge (Davis et al. 1988; Latkova, 2008). The instrument used in this study measured both indirect and direct knowledge, allowing for a comparison of the two measurements. Indirect tourism knowledge was modified from an item used by McGehee and Andereck (2004). This item was expanded into three items covering each of the following types of tourism knowledge; economic, environmental, and socio-cultural. A Likert-type scale was used for the respondents to select their particular level of tourism knowledge.

Direct level of tourism knowledge was also segmented into the categories of economic, environmental, and socio-cultural. Three multiple-choice questions were developed for each type of tourism knowledge. Two of the economic questions were developed with the help of John Sorgenfrei at TJA Advertising and Andrea Lueker, City Manager of Morro Bay. These two questions involved the Transient Occupancy Tax (TOT) rate in Morro Bay at the time of the study. One item was based on the TOT rate and the other was based on city revenue generated from TOT. Taxes and revenue generated by tourism have been previously used to measure residents' knowledge of tourism by Davis et al. (1988). The third economic knowledge item was adopted from Goeldner and Ritchie (2006b). This item was included to measure the understanding of the multiplier effect. Since a destinations multiplier is hard to quantify, this item focused on the general concept of the multiplier effect.

Few research studies have been published on the residents' level of knowledge about the environment and tourism. The three items measuring environmental tourism knowledge focused on broad potential environmental impacts of tourism. It is necessary 
for the residents to have an understanding of the potential impacts of the tourism industry so that they will be able to make informed decisions on the development of tourism in their community. One item focused on the stress that tourism can place on the natural environment (Goeldner \& Ritchie, 2006a). Another item measured the potential positive environmental impacts of the tourism industry. This item included two correct answers developed from Goeldner and Ritchie (2006a) "Can help raise awareness of environmental concerns" and "Can offer financial incentives to protect the natural environment." The final item measuring environmental tourism knowledge was developed from the UNCED Earth Summit, which identified travel and tourism as an industry that has the potential to be an environmentally friendly industry (Berry \& Ladkin, 1997).

The items used to measure socio-cultural tourism knowledge were developed in a similar manner to the environmental tourism knowledge items. The first item was adapted from Goeldner and Ritchie (2006b), and focused on a general potential positive socio-cultural impact from tourism; how tourism can offer financial incentive for cultural development and preservation. Typically, environmental and socio-cultural impacts are seen as negative. The next item was developed from Dogan (1989) on how the reproduction of cultural activities for tourists can decrease the level of authenticity. The final item measuring socio-cultural tourism knowledge focused on the general sociocultural impacts from tourism on residents, including habits, daily routines, social lives, beliefs, and values (Dogan, 1989).

The final component consisted of general demographic questions. There were four questions regarding residence in Morro Bay. The first was modified from Latkova 
(2008), which asked, "how would you describe your residence in Morro Bay?" This item was included to ensure respondents were residents of Morro Bay and whether they were a full-time resident or seasonal resident. The next item was adopted from Lankford and Howard (1994), and measured respondents' length of residency in Morro Bay. The next two questions were developed in conjunction with Dr. Walker, Assistant Professor in the Statistics department at California Polytechnic, San Luis Obispo, to determine if there was a variation of respondents' attitudes that reside in different parts of the city. The first item was "where do you live in Morro Bay" giving the options of either North or South of Highway 41. Consultation with local tourism leaders in Morro Bay and an examination of the city layout, Highway 41 was the primary geographical divider in the town. The majority of tourist attractions are found in the southern part of the town, with very few in the northern portion. Therefore, it was believed that there would be a variation of responses in each of these locations. The beach and harbor are major tourist attractions in Morro Bay. For that reason the final question regarding location of residence was "how far from the nearest body of water do you live?" Residents living closer to bodies of water may have stronger opinions toward tourism because of their proximity to the main tourist attractions.

The next section of demographic questions addressed contact with tourists. This section included two items both modified from Lankford and Howard (1994). The first item asked, "how often do you speak with tourists visiting Morro Bay," and the second item asked, "how often do you visit the Embarcadero in Morro Bay?" These items were included to understand how much contact the respondents had with tourists. At the time of the study, the Embarcadero was the primary tourist destination in Morro Bay, and 
includes numerous shops and restaurants along the harbor front. The following items were modified from McGehee and Andereck (2004) to measure the respondents' relationship to the tourism industry. The items used were "to what extent do you receive your income from the tourism industry" and "what is your occupation"? Two items were used to gain a better understanding of whether respondents were partially reliant, but not aware of their connection to the tourism industry.

The next two components were standard demographic questions including age, gender, education, and income. These items were modified from McGehee and Andereck (2004). The final component was created in conjunction with TJA Advertising to aid in the development of the social marketing campaign to raise residents' awareness and knowledge of tourism. This item asked respondents if they were interested in learning more about the tourism industry and if so, how they would like to learn about it. Table 2: Instrument variables and measurement

\begin{tabular}{lcl}
\hline Variable & Item & Source \\
\hline Attitude toward tourism & & $\begin{array}{l}\text { TIAS modified } \\
\text { from Lankford \& } \\
\text { Howard (1994) }\end{array}$ \\
$\quad \begin{array}{l}\text { Impacts on the standard of } \\
\text { living }\end{array}$ & $1-6$ & \\
$\quad \begin{array}{l}\text { Impacts on recreation services } \\
\text { \& facilities }\end{array}$ & $7-10$ & \\
$\quad \begin{array}{l}\text { Appropriate and sensitive } \\
\text { development issues }\end{array}$ & $11-22$ & \\
$\quad \begin{array}{l}\text { Government and public policy } \\
\text { About tourists in your }\end{array}$ & $23-31$ & \\
$\quad$ community & $32-34$ & \\
Community attachment & $35-39$ & $\begin{array}{l}\text { Modified from } \\
\text { McCool \& Martin } \\
\text { (1994) }\end{array}$ \\
Indirect tourism knowledge & &
\end{tabular}


Table 2: Continued

\begin{tabular}{|c|c|c|}
\hline Variable & Item & Source \\
\hline Economic & 40 & $\begin{array}{l}\text { Modified from } \\
\text { McGehee \& } \\
\text { Andereck (2004) }\end{array}$ \\
\hline Environmental & 41 & \\
\hline Socio-cultural & 42 & \\
\hline \multicolumn{3}{|c|}{ Objective tourism knowledge } \\
\hline \multirow[t]{2}{*}{ Economic } & 43 & $\begin{array}{l}\text { Adopted from } \\
\text { Goeldner \& } \\
\text { Ritichie (2006b) }\end{array}$ \\
\hline & $44-45$ & $\begin{array}{l}\text { Developed in } \\
\text { conjunctions with } \\
\text { TJA advertising } \\
\text { and Morro Bay } \\
\text { city manager }\end{array}$ \\
\hline \multirow[t]{3}{*}{ Environmental } & 46 & $\begin{array}{l}\text { Developed from } \\
\text { Goeldner \& } \\
\text { Ritchie (2006a) }\end{array}$ \\
\hline & 47 & $\begin{array}{l}\text { Developed from } \\
\text { Berry \& Ladkin } \\
\text { (1997) }\end{array}$ \\
\hline & 48 & $\begin{array}{l}\text { Developed from } \\
\text { Goeldner \& } \\
\text { Ritchie (2006a) }\end{array}$ \\
\hline \multirow[t]{2}{*}{ Socio-cultural } & 49 & $\begin{array}{l}\text { Adopted from } \\
\text { Goeldner } \& \\
\text { Ritchie }(2006 b)\end{array}$ \\
\hline & 50,51 & $\begin{array}{l}\text { Developed from } \\
\text { Dogan (1989) }\end{array}$ \\
\hline \multicolumn{3}{|l|}{ Demographics } \\
\hline \multirow[t]{2}{*}{ Residence } & 52 & $\begin{array}{l}\text { Modified from } \\
\text { Latkova (2008) }\end{array}$ \\
\hline & 55 & $\begin{array}{l}\text { Modified from } \\
\text { Lankford \& } \\
\text { Howard (1994) }\end{array}$ \\
\hline
\end{tabular}


Table 2: Continued

\begin{tabular}{lll}
\hline Variable & Item & Source \\
\hline Residence & 57,58 & $\begin{array}{l}\text { Developed in } \\
\text { conjunction with } \\
\text { Dr. Walker and } \\
\text { Morro Bay } \\
\text { tourism leaders }\end{array}$ \\
& & Modified from \\
Tourists contact & 53,59 & Lankford \& \\
& & Howard (1994) \\
Relationship to tourism & 54,62 & Modified from \\
& & McGehee \& \\
& & Andereck (2004) \\
Age & 60 & Modified from \\
& & McGehee \& \\
Gender & & Andereck (2004) \\
& 61 & Modified from \\
Education & & McGehee \& \\
& & Andereck (2004) \\
Income & 63 & Modified from \\
& & McGehee \& \\
Interest in learning more about & 56 & Andereck (2004) \\
tourism & & Modified from \\
& & McGehee \& \\
& & Andereck (2004) \\
& & Developed in \\
& & conjunction with \\
& & TJA Advertising \\
\hline
\end{tabular}

Study Procedures

Self-administered questionnaires were distributed between February and April 2011. The majority of research on residents' attitudes towards tourism has used surveybased research methods to collect data (Latkova, 2008). Surveys have been identified as valid instruments for measuring attitudes (Babbie, 1998). Dillman (1978) established one of the most commonly used survey methods called the Total Design Method, often 
referred to as Dillman's method. Since 1978, Dillman's method has been refined and updated several times, and was designed according to the principals of social exchange theory regarding why people respond to surveys (Dillman, 2007).

Dillman (2007) created the Tailored Design Method as an evolution of the Total Design Method. The Tailored Design Method was created to respond to the changes since 1978 such as, "new technologies, theoretical advancements, mixed-mode considerations, a better understanding of specific survey requirements, and an improved base of social science knowledge" (Dillman, 2007, p. 6). Dillman offered three variables for predicting whether someone will respond to a survey; rewards, cost, and trust. Increasing rewards and trust, while decreasing cost will increase the probability of someone responding to a survey. The current study used the Tailor Design Method as the foundation to build the study procedures. The Tailor Design Method suggests five elements for achieving high response rates by mail surveys (Dillman, 2007). The five elements include:

- Element 1: Respondent friendly questionnaire

- Element 2: Four contacts by first class mail

- Element 3: Return envelopes with real first-class stamps

- Element 4: Personalization of correspondence

- Element 5: Token prepaid financial incentives

These elements were used to construct the current study. Table 3 (p. 53) is a summary of the four contacts recommended in element two. 
Table 3: Four suggested contracts for mail surveys of the Tailored Design Method

\begin{tabular}{|c|c|}
\hline Contact & Components \\
\hline Pre-Notice & $\begin{array}{l}\text { Few days prior to the questionnaire } \\
\text { - Notes the survey will be coming, the importance, } \\
\text { and their response is appreciated }\end{array}$ \\
\hline Questionnaire & $\begin{array}{l}\text { - } \text { Cover letter - Explaining importance } \\
\text { - Survey } \\
\text { - Pre-paid stamped return envelop }\end{array}$ \\
\hline Thank you postcard & $\begin{array}{l}\text { - Few days to a week after questionnaire } \\
\text { - } \quad \text { Express appreciation for response } \\
\text { soon if not complete it is hoped it will be received } \\
\text { soon }\end{array}$ \\
\hline Replacement questionnaire & $\begin{array}{l}\text { - Two to four week after previous questionnaire } \\
\text { mailing } \\
\text { - Cover letter - state their survey has not been } \\
\text { received and urge them to complete and send back } \\
\text { - Survey } \\
\text { - Pre-paid return stamped envelop }\end{array}$ \\
\hline
\end{tabular}

Source: Dillman, 2007

Dillman (2007) noted several situations in which alternative questionnaire delivery methods, such as in person, to groups, and through publications were beneficial. Due to financial constraints, this study altered Dillman's element two and used two contacts with the sample population rather than four. To help increase the response rate, the questionnaires were delivered in person rather than through the mail for the first contact. By doing so, the level of personalization and trust was increased, and the respondents were given an opportunity to ask any questions they had about the study. The follow-up contact was hand-addressed and mailed first class to all non-respondents two to three weeks after the first contact was made. 
The first contact the questionnaire was delivered with the components suggested above by Dillman (2007). Similarly, the second contact included a replacement questionnaire, new cover letter, and a pre-stamped return envelope. Everyone who returned a completed questionnaire was entered in a drawing for a $\$ 100$ cash prize as incentive. The first contact cover letter can be found in Appendix B and the follow-up cover letter can be found in Appendix C.

An expert panel was asked to assess the questionnaire. The expert panel consisted of John Sorgenfrei owner and founder of TJA Advertising, and Andrea Lueker, Morro Bay City Manager. The expert panel aided in the choice of language used in the instrument and added the item asking subjects if they were interested in learning more about tourism. Twenty residents were selected from the random sample of 1,000 residents to participate in a pilot study. Of the 20 selected, 17 were deliverable, and five were returned completed. After examining the responses, no major concerns were detected. Respondents completed all questions, and no comments were made about unclear questions. No major changes were made to the instrument, allowing for the five pilot responses to be included in the study sample.

Four research assistants were trained and provided with a script (found in Appendix D) prior to administering the survey to ensure everyone in the sample received the same treatment. If the respondent was not home at the time of the delivery the questionnaire was left at the front door. From the original sample of 1000 subjects, 700 names were randomly selected using Microsoft Excel. Each subject was randomly assigned a number between zero and one, then the list of subjects was sorted in ascending order, and the first 700 were selected. The sample was then divided into four groups 
based on geographical location to make delivery more efficient. Each research assistant was given a list containing 165 to 180 addresses. The first round of questionnaires was distributed within a two-week period, in February. Delivery times varied; more questionnaires were delivered on the weekends and evenings because most respondents were expected to be home during those times.

\section{Data Analysis}

Data were entered into a Microsoft Excel spreadsheet. Each item measuring residents' attitudes was coded either positively or negatively. For example, items that were in a negative direction such as "tourism development in my community will provide less jobs for local people" were reversed so that all items were coded in a positive direction. All attitude items were averaged together to create one attitude score for each respondent. This method was also used to create a total average score for community attachment and indirect tourism knowledge. Respondents received one point for each correct response to every direct tourism knowledge question. Partial points were given for each correct response selected on the two direct tourism knowledge items that had multiple correct responses. If all correct responses were selected the respondent would receive one point. Each direct tourism knowledge category was averaged together so that each respondent had an average score for each tourism knowledge category.

A conceptual model was constructed to test for significant associations to residents' attitudes towards tourism. It can be found in Figure 4 below. Each predictor variable tested has been shown in previous research to be significantly associated to 
residents' attitude toward tourism, and was included to answer a specific research question. Figure 4 shows which predictor variables were used for each research question.

The statistical program Minitab was used to run a multiple regression analysis testing for any existing relationships. A multiple regression model was used to test all predictor variables at the same time. Using one multiple regression model rather than several simple regression models allowed for each variable to be tested after holding all other variables constant.

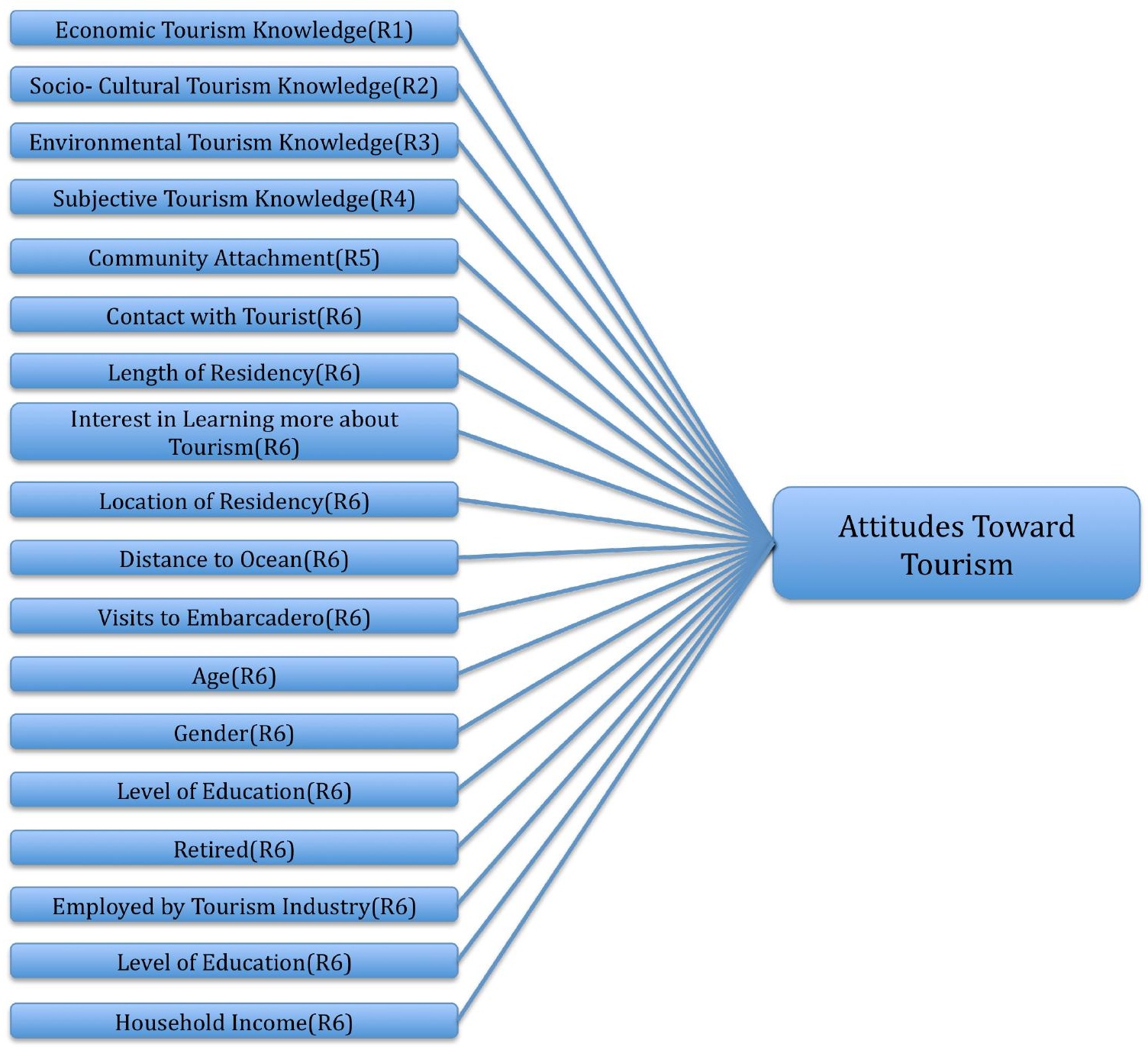

Figure 4: Proposed conceptual model with research questions in parentheses 
Chapter 4 will discuss the results discovered from the multiple regression tests conducted on the conceptual model previously presented. 


\section{CHAPTER 4}

\section{RESULTS}

The following chapter presents the results from the study conducted on residents' attitudes toward tourism in Morro Bay. This chapter is divided into five categories, sociodemographic profile, community attachment, tourism knowledge, attitudes toward tourism, and analysis of research questions.

Of the 700 selected names, 681 were deliverable, 407 were returned completed, 27 declined to participate in the study, and 286 did not respond. The follow-up was mailed out two to three weeks after the first contact to 329 residents. Twenty-seven questionnaires were returned undeliverable from the post office due to vacancy, two subjects declined to participate, and 63 questionnaires were returned completed. The total response rate for the study was $60 \%$. The complete breakdown of study responses can be found in Table 4 .

Table 4: Response Statistics

\begin{tabular}{|c|c|c|}
\hline Item & Frequency & Percentage $(\%)$ \\
\hline Sample & 720 & - \\
\hline Undeliverable & 41 & 5.69 \\
\hline Delivered & 681 & 94.58 \\
\hline Completed & 407 & 59.77 \\
\hline Non-response / Decline & 313 & 45.96 \\
\hline
\end{tabular}




\section{Socio-demographic Profile}

The following section contains the socio-demographic results, including: gender, employment status, age, residency, length of residency, location of residence, number of blocks to nearest body of water, level of education, household income, number of visits to the Embarcadero, contact with tourists, employed by the tourism industry, and interested in learning more about tourism. Of the 407 completed questionnaires 202 $(54.59 \%)$ were female and $168(45.41 \%)$ were male. Just over half of the sample was retired $(52.63 \%)$. The average age was 61.78 , with a median age of 62 , and a standard deviation of 13.77 (Figure 5).

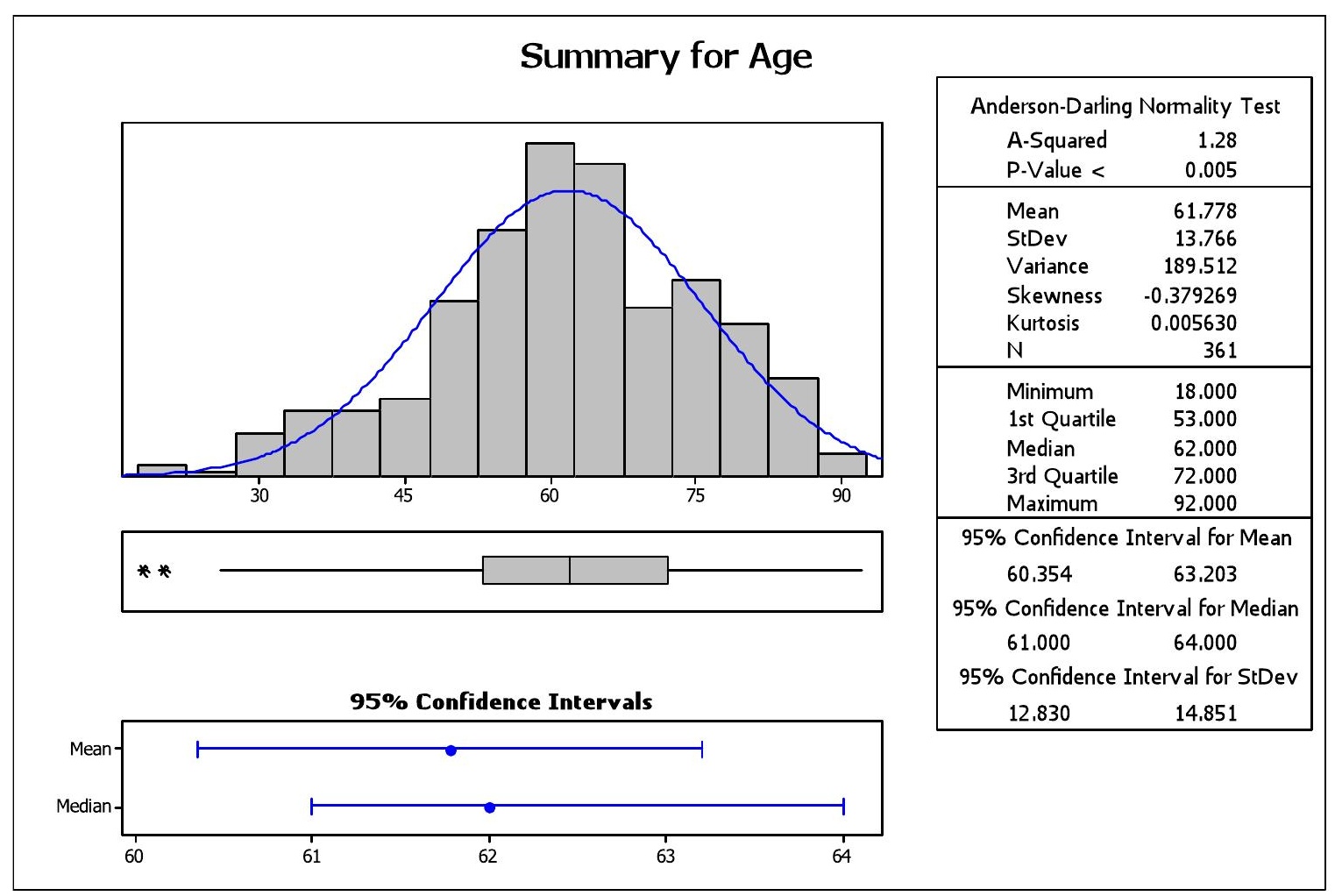

Figure 5: Age 
Three hundred and eighty subjects $(97.44 \%)$ responded that they were full-time residents of Morro Bay (Table 5, p. 59).

Table 5: Residency

\begin{tabular}{lll}
\hline Item & Frequency & Percentage (\%) \\
\hline Full-time resident & 380 & 97.44 \\
Part-time resident & 9 & 2.31 \\
Not a Morro Bay resident & 1 & 0.26 \\
\hline
\end{tabular}

Note. $\mathrm{n}=390$

Figure 6 (p. 61) shows the distribution of length of residency, which was strongly skewed right. The mean length of residency was 18.44 years, with a median of 15 years, and a standard deviation of 13.88 years. 


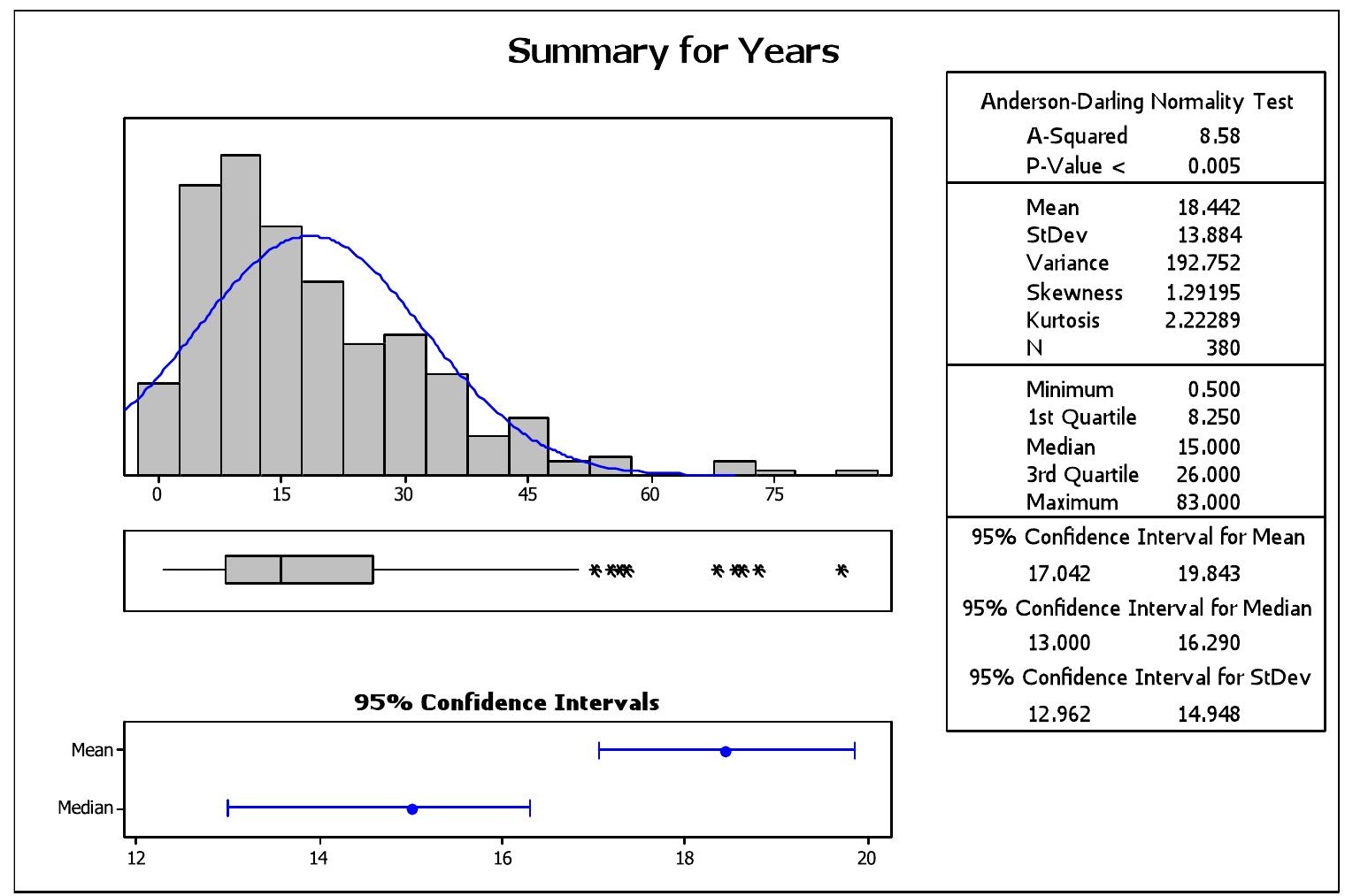

Figure 6: Length of Residency

Almost half of the respondents lived north of highway 41 / Atascadero Rd. Two hundred and seven $(55.20 \%)$ lived on the north side of town and $168(44.80 \%)$ lived on the south side of town. Most subjects lived fairly close to the beach or bay, with a mean of 5.89 blocks, and median of 5 blocks (Figure 7, p. 62). 


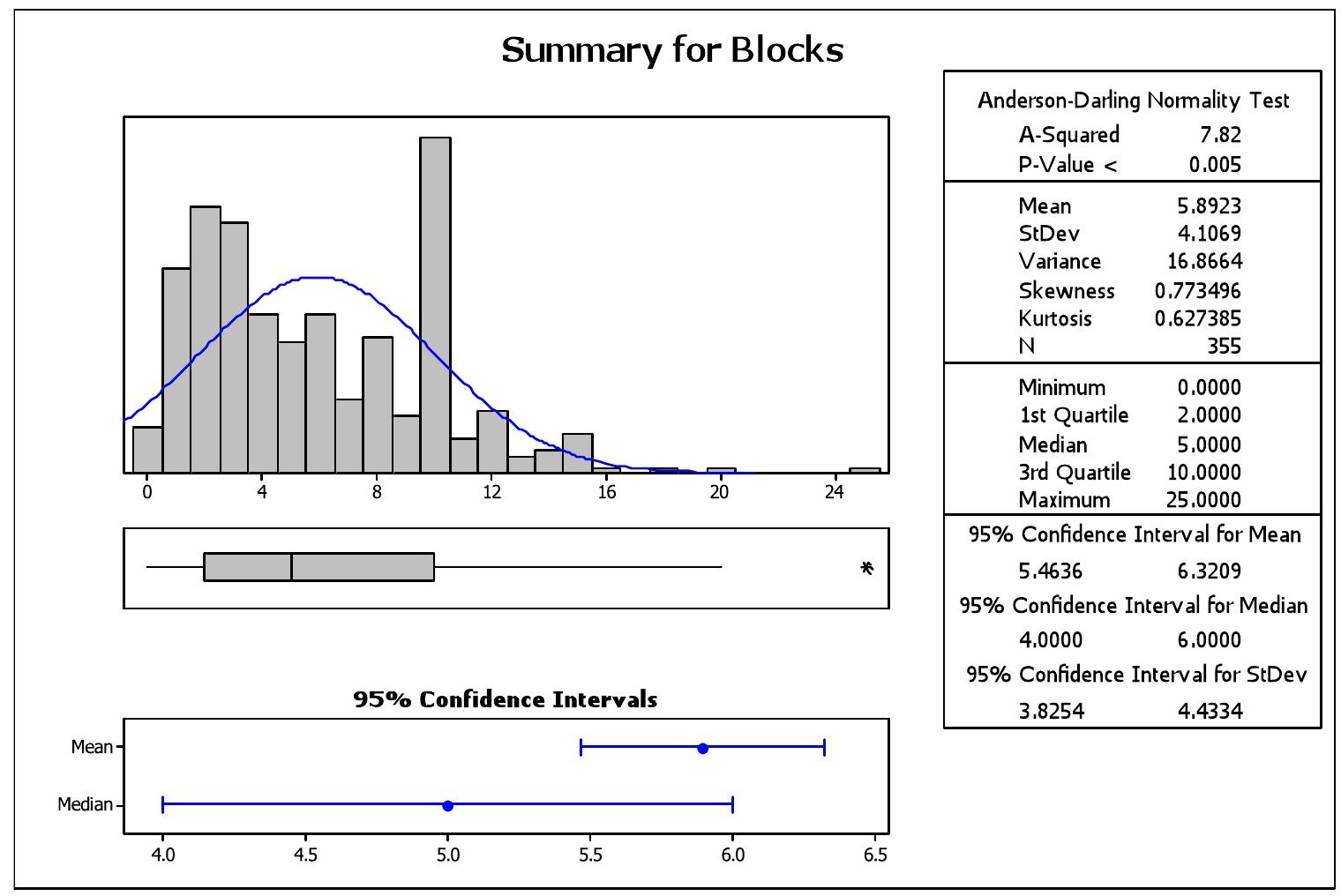

Figure 7: Number of Blocks to Nearest Body of Water

Respondents had a fairly high level of education; 222 (60\%) subjects had at least a fouryear degree (Table 6, p. 63). 
Table 6: Level of Education

\begin{tabular}{lll}
\hline Item & Frequency & Percentage (\%) \\
\hline Some high school & 2 & 0.54 \\
Completed high school & 26 & 7.03 \\
Some college & 120 & 32.43 \\
Completed four-year college degree & 80 & 21.62 \\
Some graduate work & 40 & 10.81 \\
Completed graduate degree & 102 & 27.57 \\
\hline
\end{tabular}

Note. $\mathrm{n}=370$

There was a fairly even distribution of household income levels, except for those making less than $\$ 24,999$ a year (Table 7). The results of this item indicate that the lower income residents were under represented in the sample used. A possible explanation of this may be attributed to the sample only including homeowners.

Table 7: Household Income

\begin{tabular}{lll}
\hline Item & Frequency & Percentage (\%) \\
\hline Less than $\$ 24,999$ & 20 & 5.85 \\
$\$ 25,000-\$ 49,999$ & 73 & 21.35 \\
$\$ 50,000-\$ 74,999$ & 81 & 23.68 \\
$\$ 75,000-\$ 99,999$ & 73 & 21.35 \\
$\$ 100,000$ or more & 95 & 27.78 \\
\hline
\end{tabular}

Note. $\mathrm{n}=342$ 
The majority of respondents did not visit the Embarcadero in Morro Bay very often; 292 respondents (78.49\%) visited the Embarcadero twice or less a week (Table 8).

Table 8: Numbers of Visits to the Embarcadero

\begin{tabular}{lll}
\hline Item & Frequency & Percentage (\%) \\
\hline Less than once a week & 167 & 44.89 \\
Once to twice a week & 125 & 33.60 \\
Three to four times a week & 46 & 12.37 \\
Five or more times a week & 34 & 9.14 \\
\hline
\end{tabular}

Note. $\mathrm{n}=372$

A total of $324(85.94 \%)$ respondents spoke with tourists two times or fewer per week (Table 9).

Table 9: Contact with Tourists

\begin{tabular}{lll}
\hline Item & Frequency & Percentage (\%) \\
\hline Less than once a week & 240 & 63.66 \\
Once to twice a week & 84 & 22.28 \\
Three to four times a week & 31 & 8.22 \\
Five or more times a week & 22 & 5.84 \\
\hline
\end{tabular}

Note. $\mathrm{n}=377$ 
Only $11(2.90 \%)$ respondents were directly employed in the tourism industry, and 339 (89.45\%) were not employed by the tourism industry (Table 10$)$.

Table 10: Employed by the Tourism Industry

\begin{tabular}{lll}
\hline Item & Frequency & Percentage (\%) \\
\hline Directly employed & 11 & 2.90 \\
Indirectly employed & 29 & 7.65 \\
Not employed by tourism industry & 339 & 89.45 \\
\hline
\end{tabular}

Note. $\mathrm{n}=379$

One hundred and sixty three (44.17\%) respondents were interested in learning more about the tourism industry, and $206(55.83 \%)$ were not interested in learning more about the tourism industry.

\section{Community Attachment}

Community attachment was measured by summing four Likert-type scale items and averaging them together to create one community attachment score for each subject. Table 11 shows the response breakdown for each of the four items. The item measuring community attachment that had the lowest score (2.42) was "I feel there are a lot of coastal communities that could substitute for Morro Bay in which to live.” This item was in a negative direction and was coded in reverse prior to analysis so all items were in the same direction. The item with the highest score (4.27) was "I have a lot of fond memories of past experiences with family and friends in Morro Bay.” Respondents had a 
fairly high level of community attachment with an average attachment score of 4.08 , with a standard deviation of 0.70 on a 5-point Likert-type scale (Figure 8, p. 67).

Table 11: Community Attachment

\begin{tabular}{lllllll}
\hline Item & SD (\%) & $\mathrm{D}(\%)$ & $\mathrm{N}(\%)$ & $\mathrm{A}(\%)$ & $\mathrm{SA}(\%)$ & Mean \\
\hline $\begin{array}{l}\text { I feel there are a lot of } \\
\text { coastal communities that } \\
\text { could be a substitute for } \\
\text { Morro Bay in which to }\end{array}$ & 20.80 & 40.53 & 18.40 & 16.27 & 4.00 & 2.42 \\
live* & & & & & & \\
$\begin{array}{l}\text { I have a lot of fond } \\
\text { memories of past } \\
\text { experiences with family } \\
\text { and friends in Morro Bay }\end{array}$ & 0.51 & 1.52 & 9.87 & 46.58 & 41.52 & 4.27 \\
$\begin{array}{l}\text { I have a strong emotional } \\
\text { bond to Morro Bay }\end{array}$ & 0.50 & 2.27 & 15.87 & 38.54 & 42.82 & 4.21 \\
$\begin{array}{l}\text { I feel a strong sense of } \\
\text { belonging in Morro Bay }\end{array}$ & 0.76 & 2.27 & 16.12 & 40.81 & 40.05 & 4.17 \\
$\begin{array}{l}\text { There are a few satisfactory } \\
\text { alternative communities to } \\
\text { live in compared to Morro } \\
\text { Bay }\end{array}$ & 2.78 & 14.43 & 19.49 & 33.92 & 29.37 & 3.73 \\
\hline
\end{tabular}

Note. ${ }^{*}=$ Negative items that were coded in reverse for analysis 


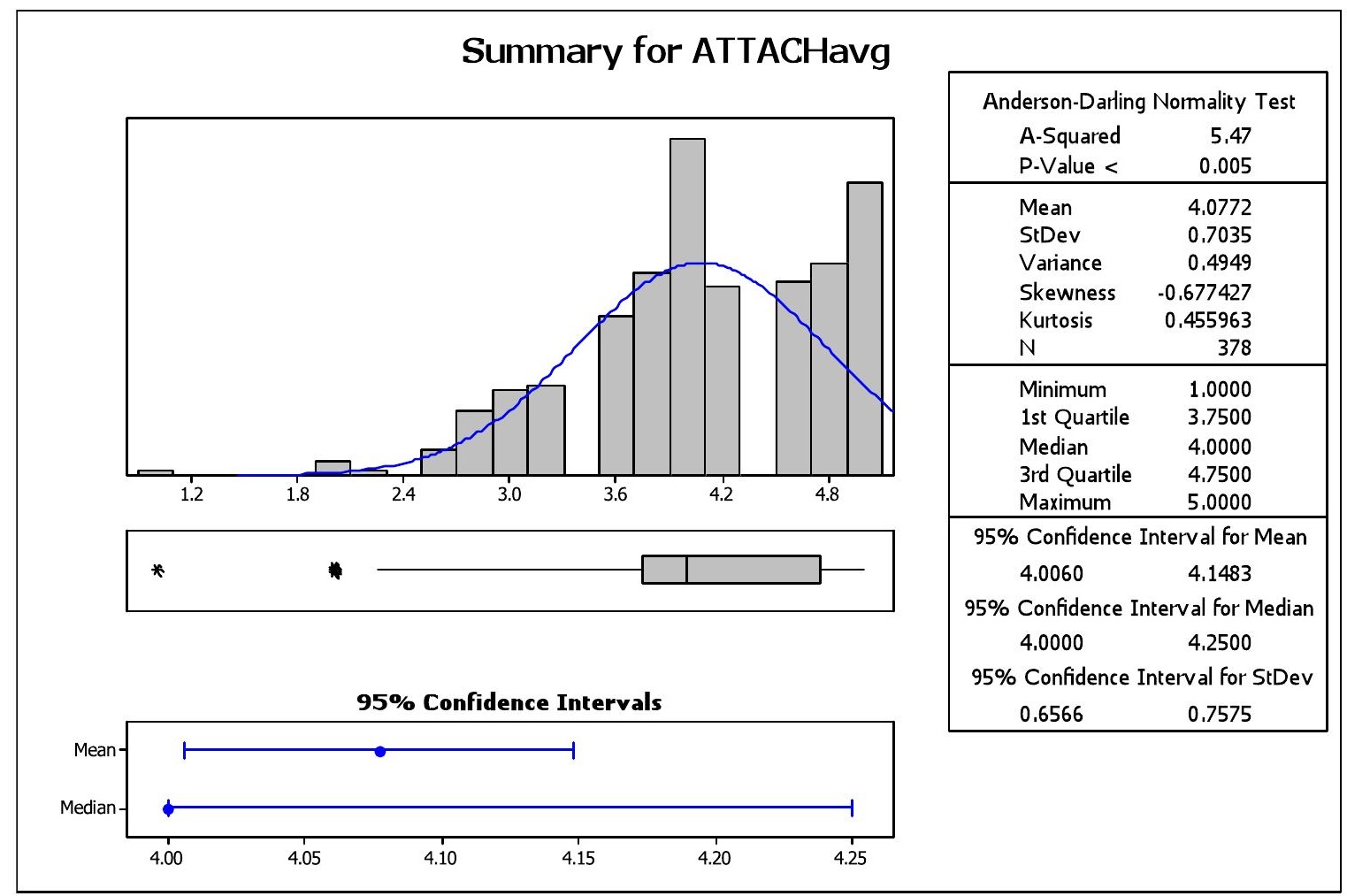

Figure 8: Level of Community Attachment

\section{Tourism knowledge}

Three 5-point Likert-type scale items were averaged together to measure indirect tourism knowledge. The three items consisted of the following statements: "I have a high level of economic tourism knowledge," "I have a high level of socio-cultural tourism knowledge," and "I have a high level of environmental tourism knowledge" (Table 12, p. 68). The subjects' indirect tourism knowledge was essentially neutral with a mean of 2.98, median of 3.00, and standard deviation of 0.85 (Figure 9, p. 68). 
Table 12: Indirect Tourism Knowledge

\begin{tabular}{lcccccc}
\hline Item & SD (\%) & D (\%) & N (\%) & A (\%) & SA (\%) & Mean \\
\hline $\begin{array}{l}\text { I have a high level of } \\
\text { economic knowledge of the } \\
\text { tourism industry }\end{array}$ & 4.29 & 30.05 & 38.38 & 21.97 & 5.30 & 2.94 \\
$\begin{array}{l}\text { I have a high level of } \\
\text { cultural knowledge of the } \\
\text { tourism industry }\end{array}$ & 3.80 & 25.32 & 41.77 & 25.06 & 4.05 & 3.00 \\
$\begin{array}{l}\text { I have a high level of } \\
\text { environmental knowledge } \\
\text { of the tourism industry }\end{array}$ & 3.54 & 24.75 & 42.42 & 24.24 & 5.30 & 3.03 \\
\hline
\end{tabular}

Note. $\mathrm{n}=396$

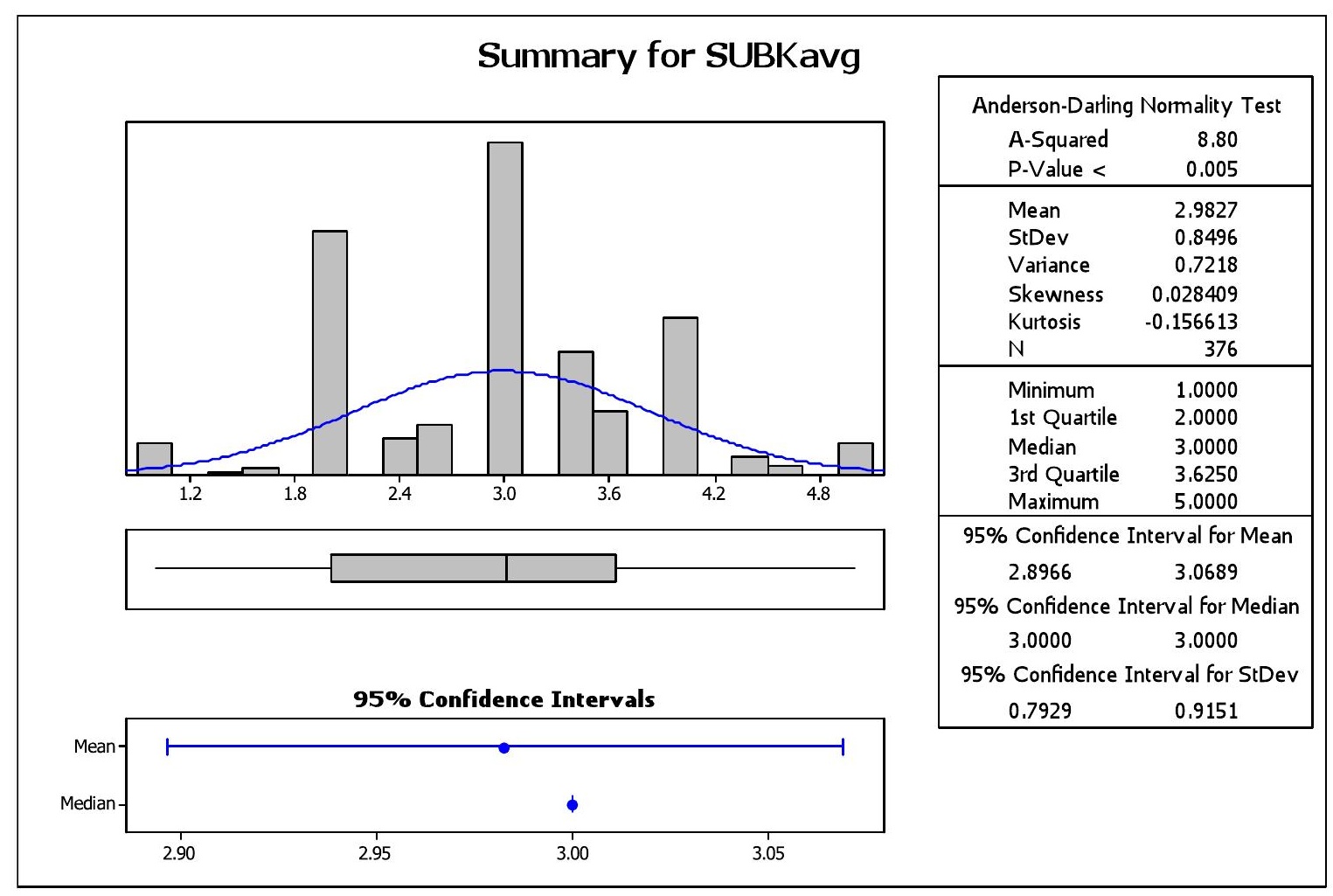

Figure 9: Level of Total Indirect Tourism Knowledge

Nine multiple-choice questions (three on economic tourism impacts, three on socio-cultural tourism impacts, and three on environmental tourism impacts) measured 
direct tourism knowledge. Subjects received one point for each correct response to every direct tourism knowledge question. For the two direct tourism knowledge items that had multiple correct responses partial points were given for each correct response that was selected. If all correct responses were selected the respondent would receive one point. Each direct tourism knowledge category was averaged together so that each subject had an average score for each type of tourism knowledge.

Direct economic tourism knowledge was assessed on understanding of tourists spending. Forty two percent of subjects understood that all residents of the community receive benefits of tourists spending (Table 13).

Table 13: Direct Economic Tourism Knowledge Question One

\begin{tabular}{lll}
\hline Which of the following is true of tourists spending? & Frequency & Percentage (\%) \\
\hline $\begin{array}{l}\text { Tourist spending is narrowly distributed within the } \\
\text { local economy }\end{array}$ & 38 & 9.92 \\
$\begin{array}{l}\text { Tourist spending is received mainly by hotels and } \\
\text { restaurants }\end{array}$ & 105 & 27.42 \\
$\begin{array}{l}\text { Tourist spending benefits mainly hospitality } \\
\text { business suppliers }\end{array}$ & 22 & 5.74 \\
$\begin{array}{l}\text { Tourist spending benefits all citizens in the } \\
\text { community (correct response) }\end{array}$ & 169 & 42.42 \\
Do not know & 49 & 12.79 \\
\hline
\end{tabular}

Note. $\mathrm{n}=383$

The majority of subjects did not know the amount of revenue generated from the transient occupant tax [TOT] in Morro Bay, less than five percent of the subjects selected the correct response (Table 14, p. 70). 
Table 14: Direct Economic Tourism Knowledge Question Two

\begin{tabular}{lll}
\hline $\begin{array}{l}\text { How much did the tax collected on occupied hotel } \\
\text { rooms in Morro Bay contribute to the general fund } \\
\text { last year? }\end{array}$ & Frequency & Percentage (\%) \\
\hline Less than $\$ 499,999$ & 16 & 4.11 \\
$\$ 500,000-\$ 999,999$ & 31 & 7.97 \\
$\$ 1,000,000-\$ 1,499,999$ & 16 & 4.11 \\
More than $\$ 1,500,000$ (correct response) & 18 & 4.63 \\
Do not know & 308 & 79.18 \\
\hline
\end{tabular}

Note. $\mathrm{n}=389$

Just over 20 percent of subjects were aware the TOT rate was 10 percent in Morro Bay (Table 15).

Table 15: Direct Economic Tourism Knowledge Question Three

\begin{tabular}{lcc}
\hline $\begin{array}{l}\text { What is the tax rate on occupied rooms that goes } \\
\text { toward Morro Bay's general fund to pay for } \\
\text { services such as the police and fire department? }\end{array}$ & Frequency & Percentage (\%) \\
& & \\
\hline $3 \%$ & 26 & 6.68 \\
$5 \%$ & 18 & 4.63 \\
$10 \%$ (correct response) & 83 & 21.34 \\
$15 \%$ & 17 & 4.37 \\
Do not know & 245 & 62.98 \\
\hline
\end{tabular}

Note. $\mathrm{n}=389$ 
Respondents' direct economic tourism knowledge had a mean score of 0.23 , a median score of 0.33 , and standard deviation of 0.25 (Figure 10).

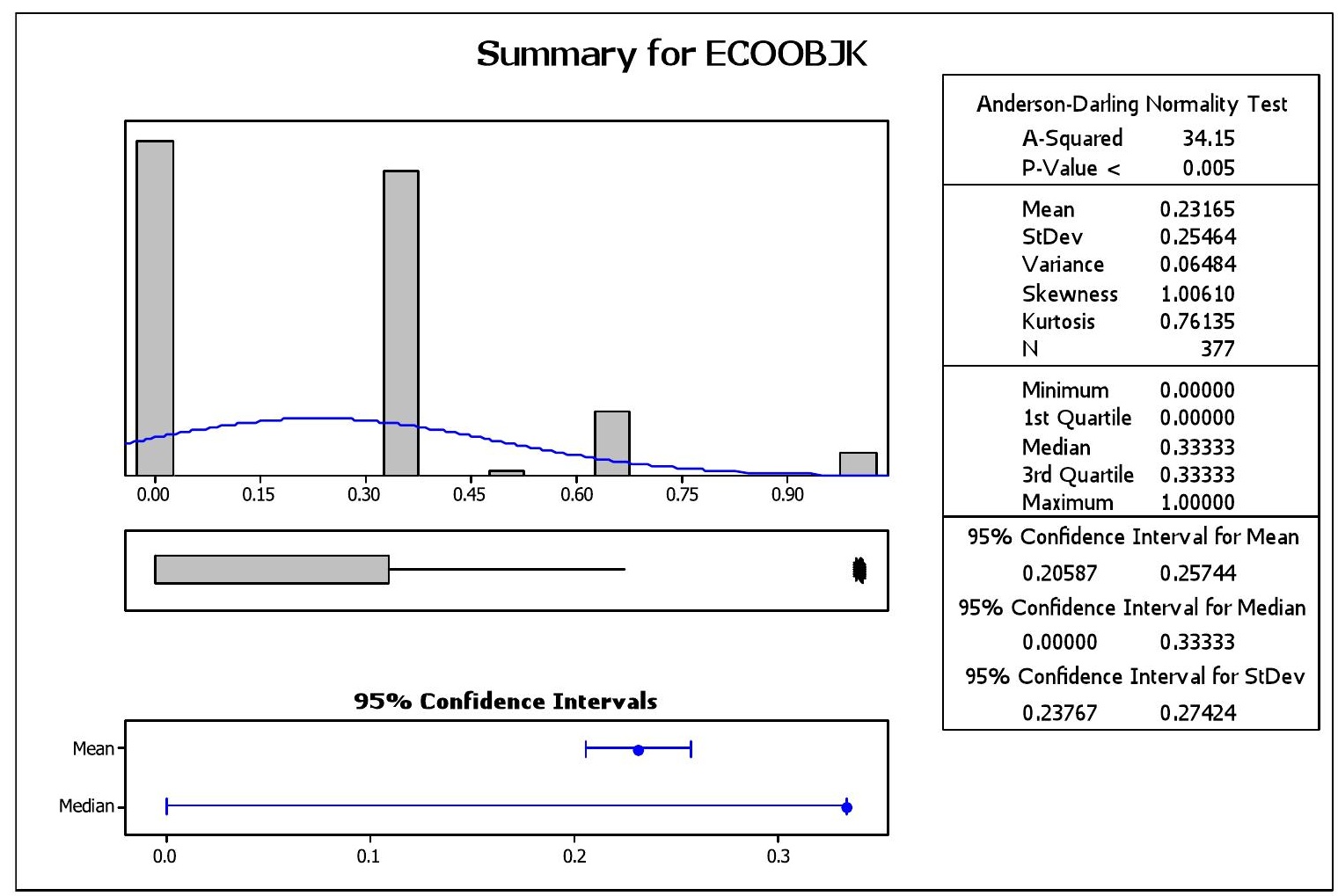

Figure 10: Level of Direct Economic Tourism Knowledge

Fifty one percent of subjects were aware that tourism can offer incentives for cultural development and preservation (Table 16, p. 72). 
Table 16: Direct Socio-cultural Tourism Knowledge Question One

\begin{tabular}{lll}
\hline Tourism: & Frequency & Percentage (\%) \\
\hline $\begin{array}{l}\text { Can offer incentives for cultural development and } \\
\text { preservation (correct response) }\end{array}$ & 196 & 50.91 \\
$\begin{array}{l}\text { Makes it virtually impossible to distinguish } \\
\text { between destinations }\end{array}$ & 4 & 1.04 \\
Has little effect on local culture & 28 & 7.27 \\
$\begin{array}{l}\text { Tends to dull people's appreciation of their cultural } \\
\text { heritage }\end{array}$ & 12 & 3.12 \\
Has only a slight connection with culture & 58 & 15.06 \\
Do not know & 87 & 22.60 \\
\hline
\end{tabular}

Note. $\mathrm{n}=385$

Although half of the subjects were of aware of how tourism could have a positive impact on culture by increasing incentives for preservation, only eight percent were aware that tourism could decrease authenticity of cultural activities (Table 17).

Table 17: Direct Socio-cultural Tourism Knowledge Question Two

\begin{tabular}{lll}
\hline $\begin{array}{l}\text { The reproduction of cultural activities for tourists } \\
\text { can have the following impact }\end{array}$ & Frequency & Percentage (\%) \\
\hline $\begin{array}{l}\text { Decrease the authenticity of cultural activities } \\
\text { (correct response) }\end{array}$ & 30 & 7.87 \\
$\begin{array}{l}\text { Increase the authenticity of cultural activities } \\
\begin{array}{l}\text { Will not have an impact of the authenticity of } \\
\text { cultural activities }\end{array}\end{array}$ & 90 & 23.62 \\
$\begin{array}{l}\text { Cultural activities are not reproduced for tourists } \\
\text { Do not know }\end{array}$ & 46 & 17.32 \\
\hline
\end{tabular}

Note. $\mathrm{n}=381$ 
The following item had four correct responses. Over half of the subject were aware tourism can affect residents daily routines and social lives, although, just of ten percent were aware tourism could influence their beliefs and value (Table 18).

Table 18: Direct Socio-cultural Tourism Knowledge Question Three

\begin{tabular}{lll}
\hline $\begin{array}{l}\text { Out of the following, which can be affected by the } \\
\text { presence of tourism for local residents? }\end{array}$ & Frequency & Percentage (\%) \\
\hline Daily routines (correct response) & 205 & 51.12 \\
Social lives (correct response) & 234 & 58.35 \\
Beliefs (correct response) & 41 & 10.22 \\
Values (correct response) & 54 & 13.47 \\
Do not know & 67 & 16.71 \\
\hline
\end{tabular}

Note. $\mathrm{n}=401$

Respondents' direct socio-cultural tourism knowledge has a mean score of 0.33 , a median score of 0.33 , and standard deviation 0.21 (Figure 11, p. 74). 


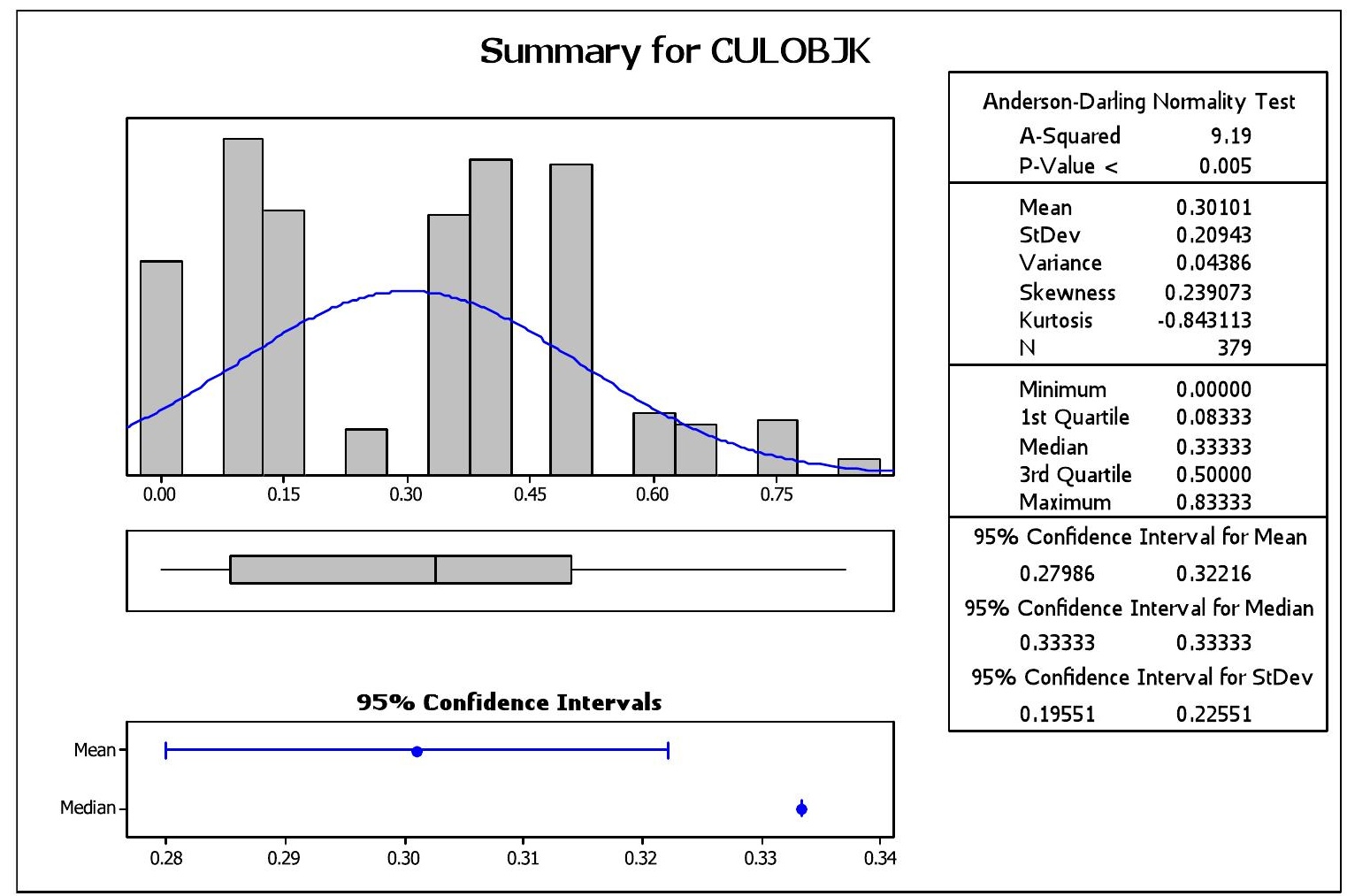

Figure 11: Level of Direct Socio-cultural Tourism Knowledge

Almost 40 percent of subjects were aware that tourism could increase negative impacts to the local economy (Table 19, p. 75). 
Table 19: Direct Environmental Tourism Knowledge Question One

\begin{tabular}{lll}
\hline $\begin{array}{l}\text { Which of the following is true in regards to tourism } \\
\text { and the natural environment? }\end{array}$ & Frequency & Percentage (\%) \\
\hline $\begin{array}{l}\text { Tourism generally has a minimal impact on the } \\
\text { local environment because tourists are experiencing } \\
\text { the destination not extracting resources }\end{array}$ & 104 & 26.87 \\
$\begin{array}{l}\text { Tourism can increase negative impacts on the local } \\
\text { environment (correct response) }\end{array}$ & 150 & 38.76 \\
$\begin{array}{l}\text { Tourism only impact the environment during peak } \\
\text { seasons }\end{array}$ & 50 & 12.92 \\
None of the above & 19 & 4.91 \\
Do not know & 64 & 16.54 \\
\hline
\end{tabular}

Note. $\mathrm{n}=387$

Nearly half of the subjects were aware that tourism has the potential to be an environmentally friendly industry (Table 20).

Table 20: Direct Environmental Tourism Knowledge Question Two

\begin{tabular}{lll}
\hline The tourism industry: & Frequency & Percentage (\%) \\
\hline Does not have any serious environmental impacts & 48 & 12.47 \\
$\begin{array}{l}\text { Has the potential to be an environmentally friendly } \\
\text { industry (correct response) }\end{array}$ & 190 & 49.35 \\
$\begin{array}{l}\text { Will have just as many negative environmental } \\
\text { impacts as most traditional industries }\end{array}$ & 84 & 21.84 \\
$\begin{array}{l}\text { Is worse for the environment than traditional } \\
\text { industries }\end{array}$ & 17 & 4.37 \\
\begin{tabular}{l} 
Do not know \\
\hline
\end{tabular} & 46 & 11.95 \\
\hline
\end{tabular}

Note. $\mathrm{n}=385$ 
The following item had two correct responses. Seventy percent of subjects were aware tourism can help raise awareness of environmental concerns and 39 percent were aware tourism could offer financial incentives (Table 21).

Table 21: Direct Environmental Tourism Knowledge Question Three

\begin{tabular}{lll}
\hline $\begin{array}{l}\text { Tourism can offer what benefits to the local } \\
\text { environment? }\end{array}$ & Frequency & Percentage (\%) \\
\hline $\begin{array}{l}\text { Can help raise awareness of environmental } \\
\text { concerns (correct response) }\end{array}$ & 282 & 12.47 \\
$\begin{array}{l}\text { Can offer financial incentives to protect the natural } \\
\text { environment (correct response) }\end{array}$ & 155 & 49.35 \\
$\begin{array}{l}\text { Can help decrease the amount of pollution } \\
\begin{array}{l}\text { Tourism only negatively impacts the environment } \\
\text { None of the above }\end{array}\end{array}$ & 44 & 21.84 \\
\hline
\end{tabular}

Note. $\mathrm{n}=401$

Respondents' direct environmental tourism knowledge has a mean score of 0.45 and a median score of 0.50 (Figure 12, p. 77). 


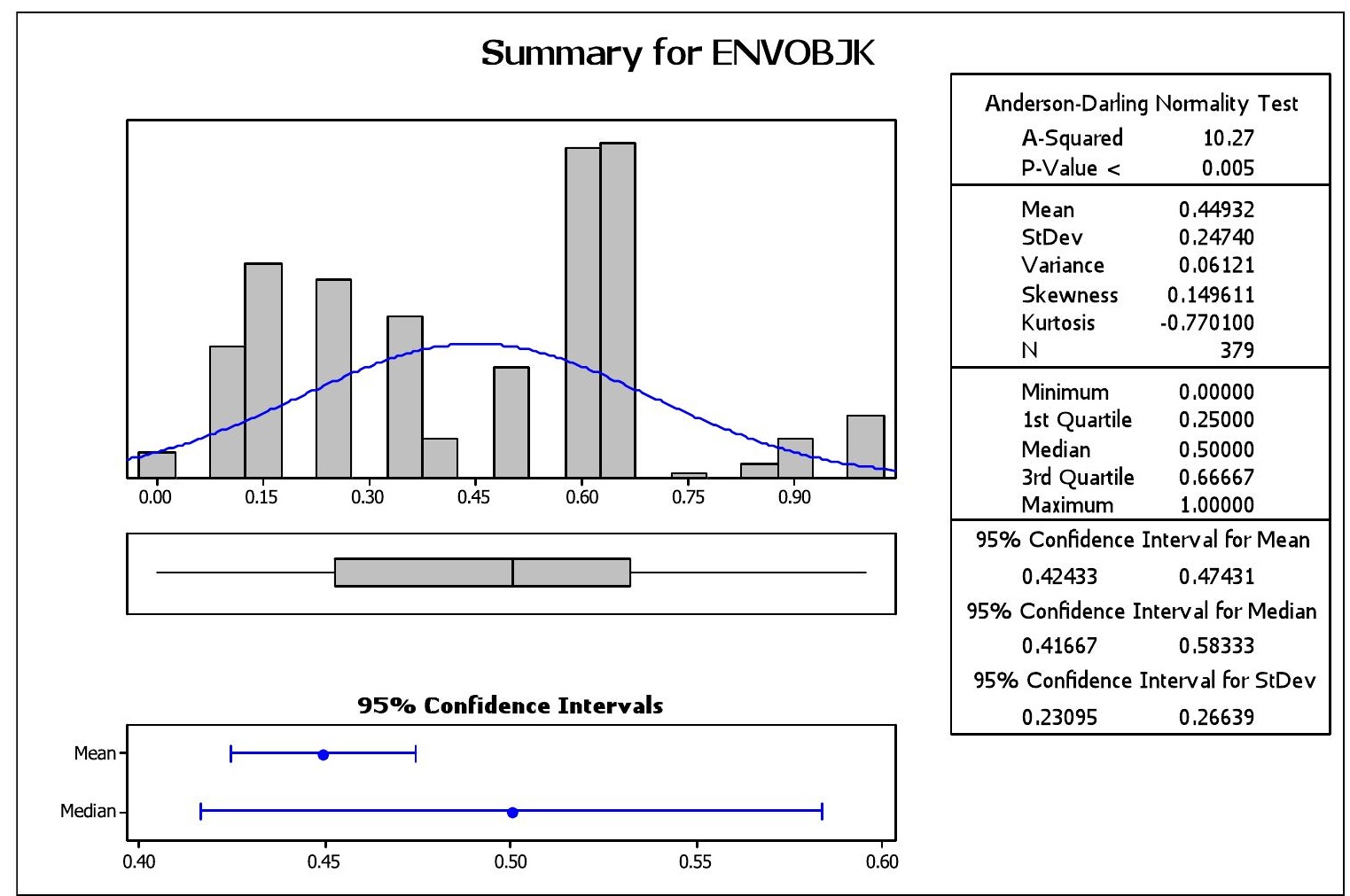

Figure 12: Level of Direct Environmental Tourism Knowledge

Figure 13 (p. 78) shows the distribution of subjects' total direct tourism

knowledge scores. Respondents' had a mean score of 0.33 and median score of 0.33 , and standard deviation of 0.17 for all direct tourism items. 


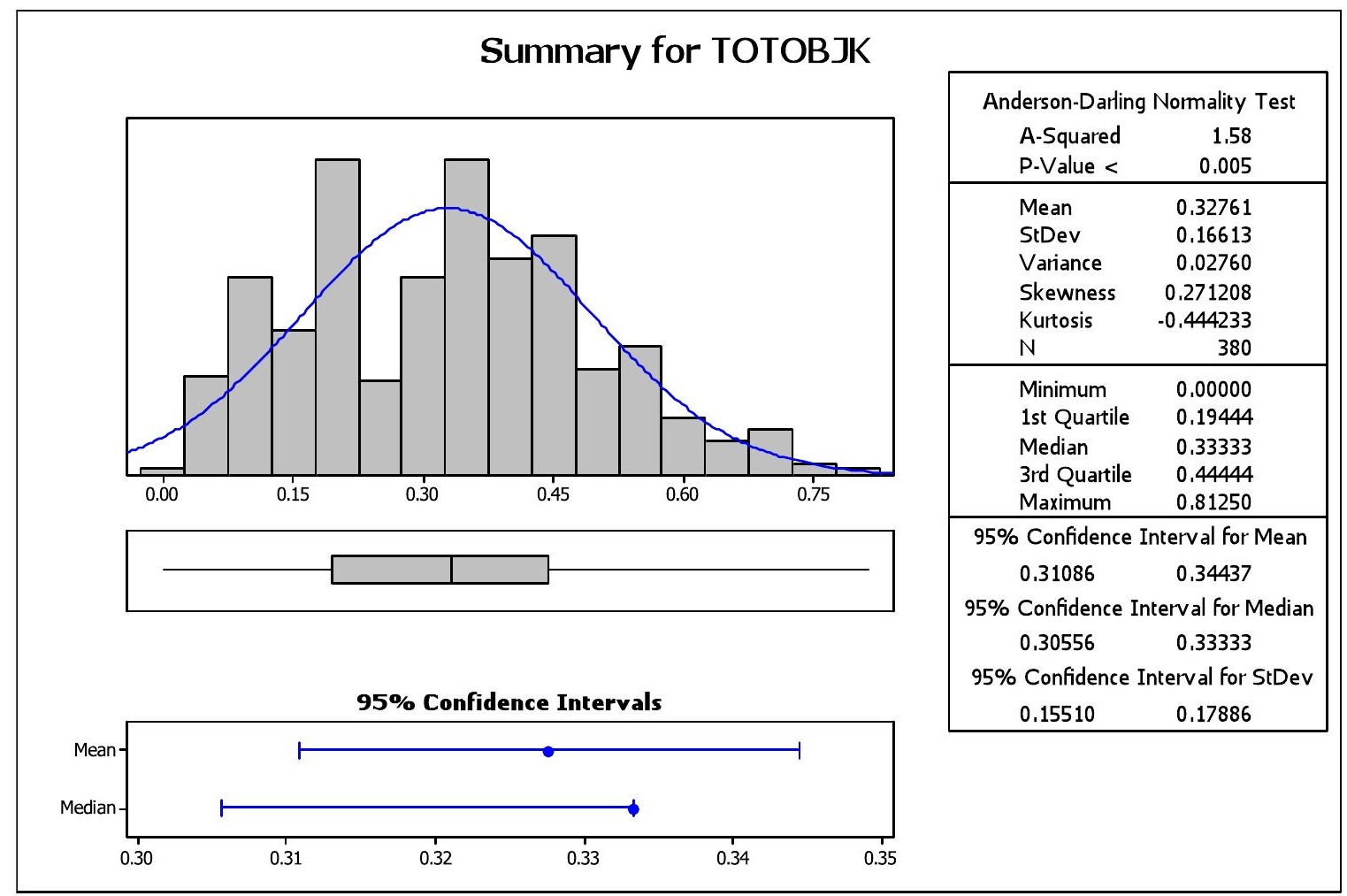

Figure 13: Level of Total Direct Tourism Knowledge

\section{Attitudes Toward Tourism}

Residents' attitudes toward tourism were measured by asking subjects to respond to 34 statements on a 5-point Likert-type scale (Table 22, p. 79). Responses were coded one through five and negative items were reversed so every item was coded in the same direction. Subjects' mean attitude toward tourism was 3.27, with a median score of 3.36 , and a standard deviation of 0.53 (Figure 14, p. 83). With 95\% confidence, the average attitude towards tourism of Morro Bay homeowners was between 3.22 and 3.33 on the 5point Likert-type scale. This is slightly higher than the neutral rating of 3 points. The item that subjects agreed with the most was "the tourism industry will continue to play a major economic role in my community," with an average score of 4.22 . The item that 
subjects disagreed with the most was "my community has better roads due to tourism," with an average score of 2.31 .

Table 22: Attitudes' Toward Tourism

\begin{tabular}{|c|c|c|c|c|c|c|}
\hline Item & $\mathrm{SD}(\%)$ & $\mathrm{D}(\%)$ & $\mathrm{N}(\%)$ & A (\%) & SA (\%) & Mean \\
\hline $\begin{array}{l}\text { Tourism in my community } \\
\text { has increased my own } \\
\text { standard of living }\end{array}$ & 6.53 & 21.36 & 40.20 & 22.86 & 9.05 & 3.06 \\
\hline $\begin{array}{l}\text { Tourism development in } \\
\text { my community will } \\
\text { provide more jobs for local } \\
\text { people }\end{array}$ & 1.00 & 3.99 & 8.23 & 50.12 & 36.66 & 4.17 \\
\hline $\begin{array}{l}\text { I have less money to spend } \\
\text { as a result of tourism* }\end{array}$ & 32.66 & 37.94 & 24.37 & 4.02 & 1.01 & 2.03 \\
\hline $\begin{array}{l}\text { I support tourism and } \\
\text { would like to it become the } \\
\text { main industry in my } \\
\text { community }\end{array}$ & 7.30 & 13.10 & 27.96 & 32.24 & 19.40 & 3.43 \\
\hline $\begin{array}{l}\text { The tourism industry will } \\
\text { continue to play a major } \\
\text { economic role in my } \\
\text { community }\end{array}$ & 1.00 & 1.50 & 9.00 & 50.75 & 37.75 & 4.22 \\
\hline $\begin{array}{l}\text { The jobs tourism provides } \\
\text { are not highly desirable } \\
\text { jobs* }\end{array}$ & 9.52 & 27.82 & 29.07 & 28.32 & 5.26 & 3.08 \\
\hline $\begin{array}{l}\text { Local recreation programs } \\
\text { have expanded due to the } \\
\text { influx of tourists to my } \\
\text { community }\end{array}$ & 4.57 & 25.13 & 40.36 & 24.37 & 5.58 & 3.01 \\
\hline $\begin{array}{l}\text { More outdoor recreation } \\
\text { development is desirable in } \\
\text { my community }\end{array}$ & 1.26 & 4.80 & 20.96 & 50.25 & 22.73 & 3.88 \\
\hline
\end{tabular}


Table 22: Continued

\begin{tabular}{|c|c|c|c|c|c|c|}
\hline Item & $\mathrm{SD}(\%)$ & $\mathrm{D}(\%)$ & $\mathrm{N}(\%)$ & A (\%) & SA (\%) & Mean \\
\hline $\begin{array}{l}\text { It is more important to } \\
\text { provide recreation facilities } \\
\text { for local people rather than } \\
\text { tourists* }\end{array}$ & 3.02 & 18.39 & 28.97 & 33.75 & 15.87 & 3.41 \\
\hline $\begin{array}{l}\text { Tourism has reduced the } \\
\text { quality of outdoor } \\
\text { recreation opportunities in } \\
\text { my community* }\end{array}$ & 13.16 & 50.89 & 25.57 & 8.35 & 2.03 & 2.36 \\
\hline $\begin{array}{l}\text { I am against new tourism } \\
\text { facilities that will attract } \\
\text { more tourists in my } \\
\text { community* }\end{array}$ & 19.95 & 45.20 & 18.43 & 11.11 & 5.30 & 2.37 \\
\hline $\begin{array}{l}\text { The noise level from the } \\
\text { existing tourism facilities is } \\
\text { not appropriate for my } \\
\text { community* }\end{array}$ & 19.44 & 49.24 & 21.97 & 6.31 & 3.03 & 2.24 \\
\hline $\begin{array}{l}\text { My community should } \\
\text { encourage more intensive } \\
\text { development of tourists } \\
\text { facilities }\end{array}$ & 4.59 & 19.90 & 26.79 & 35.20 & 13.52 & 3.33 \\
\hline $\begin{array}{l}\text { Shopping opportunities are } \\
\text { better in my community as } \\
\text { a result of tourism }\end{array}$ & 9.67 & 31.55 & 23.66 & 28.50 & 6.62 & 2.91 \\
\hline $\begin{array}{l}\text { Tourism has negatively } \\
\text { impacted the environment* }\end{array}$ & 9.44 & 47.96 & 23.47 & 14.03 & 5.10 & 2.58 \\
\hline $\begin{array}{l}\text { I believe tourism should be } \\
\text { actively encouraged in my } \\
\text { community }\end{array}$ & 3.03 & 6.31 & 19.19 & 52.02 & 19.44 & 3.78 \\
\hline $\begin{array}{l}\text { I believe tourism should be } \\
\text { encouraged in the State of } \\
\text { California }\end{array}$ & 1.01 & 3.53 & 15.87 & 53.15 & 26.45 & 4.12 \\
\hline $\begin{array}{l}\text { I support tourism as having } \\
\text { a vital role in my } \\
\text { community }\end{array}$ & 1.52 & 6.35 & 14.72 & 52.28 & 25.13 & 3.93 \\
\hline
\end{tabular}


Table 22: Continued

\begin{tabular}{|c|c|c|c|c|c|c|}
\hline $\begin{array}{l}\text { Item } \\
\end{array}$ & SD (\%) & $\overline{\mathrm{D}(\%)}$ & $\overline{\mathrm{N}(\%)}$ & A (\%) & $\begin{array}{l}\text { SA (\%) } \\
\end{array}$ & Mean \\
\hline $\begin{array}{l}\text { I support tourism as having } \\
\text { a vital role in my } \\
\text { community }\end{array}$ & 3.30 & 11.93 & 18.53 & 45.18 & 21.07 & 3.68 \\
\hline $\begin{array}{l}\text { We should not try to attract } \\
\text { more visitors* }\end{array}$ & 22.78 & 47.85 & 12.66 & 11.90 & 4.81 & 2.28 \\
\hline $\begin{array}{l}\text { My community is growing } \\
\text { too rapidly due to tourism * }\end{array}$ & 24.81 & 48.10 & 19.49 & 4.81 & 2.78 & 2.13 \\
\hline $\begin{array}{l}\text { My community should } \\
\text { become less of a tourists } \\
\text { destination* }\end{array}$ & 28.10 & 45.82 & 16.20 & 7.34 & 2.53 & 2.11 \\
\hline $\begin{array}{l}\text { The quality of public } \\
\text { service has improved due } \\
\text { to more tourism in my } \\
\text { community }\end{array}$ & 5.04 & 28.21 & 41.81 & 28.21 & 5.29 & 2.92 \\
\hline $\begin{array}{l}\text { I would support local tax } \\
\text { levies for tourism } \\
\text { development }\end{array}$ & 25.89 & 34.52 & 23.10 & 13.71 & 2.79 & 2.33 \\
\hline $\begin{array}{l}\text { My community has better } \\
\text { roads due to tourism }\end{array}$ & 20.00 & 42.53 & 25.57 & 10.38 & 1.52 & 2.31 \\
\hline $\begin{array}{l}\text { There is more litter in my } \\
\text { community due to tourism* }\end{array}$ & 4.57 & 29.70 & 25.89 & 31.98 & 7.87 & 3.09 \\
\hline $\begin{array}{l}\text { Tourism has increased } \\
\text { crime in my community * }\end{array}$ & 8.84 & 36.36 & 37.37 & 12.88 & 4.55 & 2.68 \\
\hline $\begin{array}{l}\text { The local government was } \\
\text { right in approving the } \\
\text { promotion of tourism to } \\
\text { Morro Bay }\end{array}$ & 3.55 & 6.60 & 19.80 & 50.76 & 19.29 & 3.75 \\
\hline $\begin{array}{l}\text { City officials listen to } \\
\text { residents about their } \\
\text { concerns with tourism }\end{array}$ & 8.38 & 15.74 & 47.97 & 24.62 & 3.30 & 2.98 \\
\hline
\end{tabular}


Table 22: Continued

\begin{tabular}{lllllll}
\hline Item & $\mathrm{SD}(\%)$ & $\mathrm{D}(\%)$ & $\mathrm{N}(\%)$ & $\mathrm{A}(\%)$ & $\mathrm{SA}(\%)$ & Mean \\
\hline $\begin{array}{l}\text { I feel I cannot access the } \\
\text { decision making process to }\end{array}$ & 2.80 & 3.333 & 43.00 & 17.05 & 3.82 & 2.86 \\
$\begin{array}{l}\text { influence future tourism } \\
\text { development in my } \\
\text { community* }\end{array}$ & & & & & & \\
$\begin{array}{l}\text { Long-term planning by my } \\
\text { city will not control the } \\
\text { negative impacts of tourism } \\
\text { on the environment* }\end{array}$ & 9.77 & 41.65 & 26.74 & 17.48 & 4.37 & 2.65 \\
$\begin{array}{l}\text { Tourists are valuable } \\
\begin{array}{l}\text { Tourists interfere with my } \\
\text { enjoyment of this town* }\end{array}\end{array}$ & 15.01 & 43.51 & 18.58 & 18.07 & 4.83 & 2.55 \\
$\begin{array}{l}\text { Most residents like tourists } \\
\text { in my community }\end{array}$ & 2.81 & 15.05 & 41.33 & 37.24 & 3.57 & 3.24 \\
\hline
\end{tabular}

Note. $*=$ Items tested in negative direction 


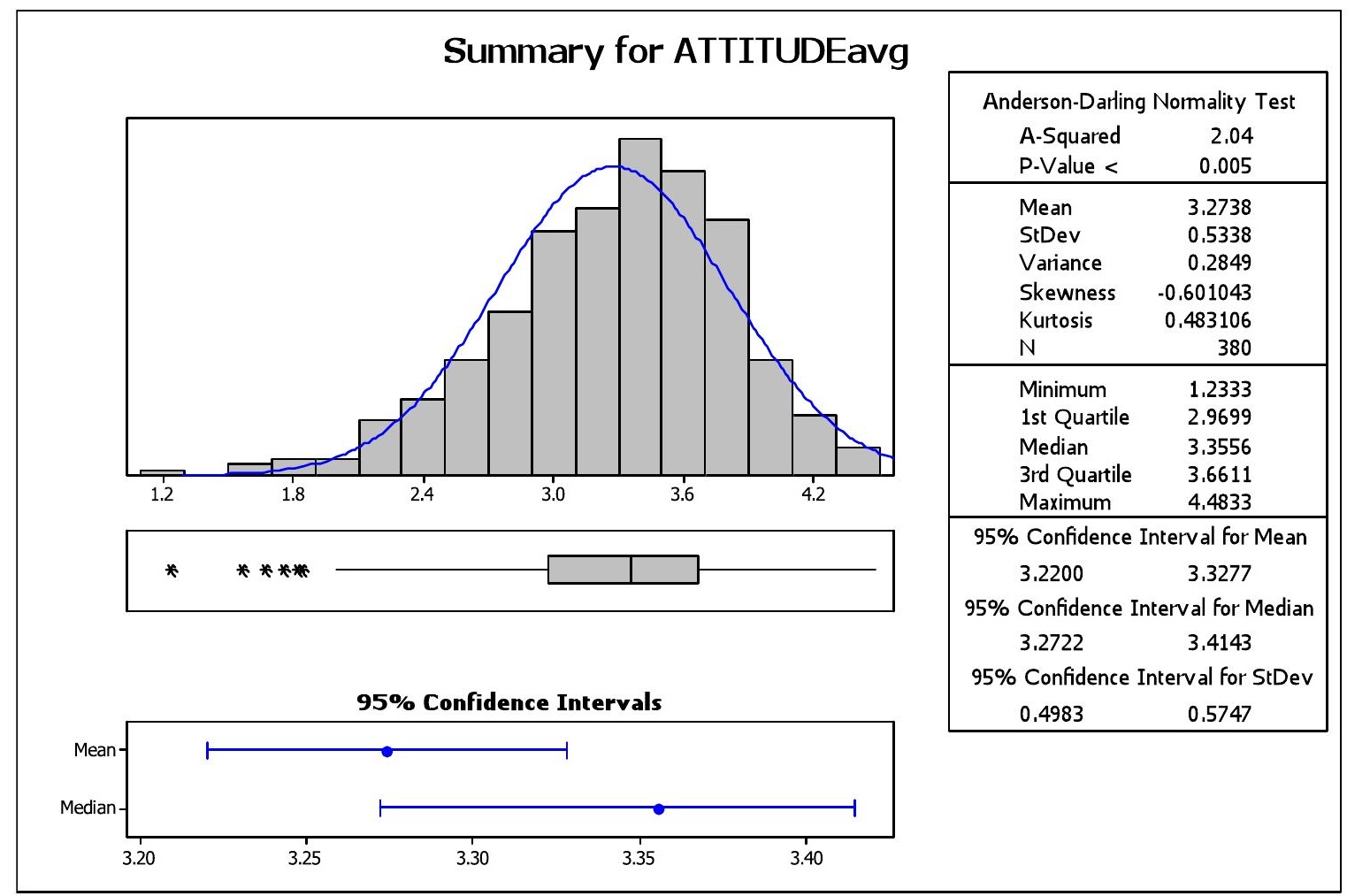

Figure 14: Attitude towards tourism

\section{Analysis of Research Questions}

A multiple regression model was run using the General Regression command in Minitab, which included all of the variables in the conceptual model (Figure 4).

Originally there were six indicator variables for the predictor variable "level of education." Initially, there was a multicollinnearity issue with this variable. The indicator variable "some high school education" had a variance inflation factor (VIF) score of 26.64. VIF quantifies the severity of multicollinnearity in a regression analysis. Kutner, Nachtsheim, and Neter (2004) indicated that a VIF score greater than ten suggests strong multicollinearity. The multicollinearity was likely caused by the fact that only two subjects reported an education level of "some high school". To correct the multicollinearity, the categories for "some high school" and "completed high school" 
were combined. As a result, the new indicator variable "completed high school or less" had a much lower VIF score of 3.59.

Figure 15 (p. 87) shows the residual plots for the regression model to assess the model's overall fit. The normal probability plot and histogram show that the residuals are symmetrical, although not exactly a normal distribution. This was not a concern due to the large sample size. Since no curve patterns were found in either Residual versus Fits or Residual versus predictor variable plots (Appendix E), we felt comfortable that the relationships described by the conceptual model are linear. Since the model assumptions were satisfied, the research questions were assessed at a 5\% significance level. Table 23 shows the results for the multiple regression analysis.

Table 23: Results of Multiple Regression Analysis

\begin{tabular}{|c|c|c|c|c|}
\hline Predictor Variable & Coefficient & $P-$ Value & $\begin{array}{l}95 \% \\
\text { Confidence } \\
\text { Interval }\end{array}$ & VIF \\
\hline Contact with tourists & - & 0.796 & - & - \\
\hline Less than once a week & -0.011 & 0.842 & $(-0.120,0.098)$ & 1.565 \\
\hline Once to twice a week & 0.026 & 0.666 & $(-0.092,0.145)$ & 1.375 \\
\hline Three to four a week & -0.070 & 0.384 & $(-0.227,0.088)$ & 1.283 \\
\hline Five or more a week & 0.055 & - & - & - \\
\hline Length of Residency & -0.005 & 0.020 & $(-0.010,-0.001)$ & 1.319 \\
\hline $\begin{array}{l}\text { Interested in learning more } \\
\text { about tourism }\end{array}$ & - & 0.011 & - & - \\
\hline No & -0.076 & 0.011 & $(-0.135,-0.018)$ & 1.174 \\
\hline Yes & 0.076 & - & - & - \\
\hline
\end{tabular}


Table 23: Continued

\begin{tabular}{|c|c|c|c|c|}
\hline Predictor Variable & Coefficient & $\mathrm{P}-$ Value & $\begin{array}{l}95 \% \\
\text { Confidence } \\
\text { Interval }\end{array}$ & VIF \\
\hline Location of Residency & - & 0.123 & - & - \\
\hline North of Hwy 41 & 0.047 & 0.123 & $(-0.013,0.109)$ & 1.281 \\
\hline South of Hwy 41 & -0.047 & 一 & 一 & - \\
\hline Blocks to nearest body of water & 0.010 & 0.146 & $(-0.004,0.024)$ & 1.147 \\
\hline Visits to Embarcadero & - & 0.323 & - & - \\
\hline Less than once a week & -0.062 & 0.243 & $(-0.165,0.042)$ & 1.600 \\
\hline Once to twice a week & 0.069 & 0.179 & $(-0.032,0.169)$ & 1.350 \\
\hline Three to four a week & -0.018 & 0.785 & $(-0.146,0.111)$ & 1.418 \\
\hline Five or more a week & 0.011 & 一 & - & - \\
\hline Age & 0.003 & 0.369 & $(-0.003,0.008)$ & 2.192 \\
\hline Gender & - & 0.674 & - & - \\
\hline Female & -0.013 & 0.674 & $(-0.072,0.046)$ & 1.194 \\
\hline Male & 0.013 & - & - & - \\
\hline Level of Education & - & 0.052 & - & - \\
\hline $\begin{array}{l}\text { Completed high school } \\
\text { or less }\end{array}$ & 0.264 & 0.005 & $(0.079,0.448)$ & 3.593 \\
\hline Some college & -0.071 & 0.172 & $(-0.174,0.031)$ & 2.178 \\
\hline $\begin{array}{l}\text { Completed } 4 \text { year } \\
\text { college degree }\end{array}$ & -0.094 & 0.113 & $(-0.211,0.022)$ & 2.347 \\
\hline Some graduate work & -0.002 & 0.981 & $(-0.149,0.146)$ & 2.711 \\
\hline $\begin{array}{l}\text { Completed graduate } \\
\text { degree }\end{array}$ & -0.097 & - & - & - \\
\hline Income & - & 0.066 & - & - \\
\hline
\end{tabular}


Table 23: Continued

\begin{tabular}{|c|c|c|c|c|}
\hline Predictor Variable & Coefficient & $\mathrm{P}-$ Value & $\begin{array}{l}95 \% \\
\text { Confidence } \\
\text { Interval }\end{array}$ & VIF \\
\hline Less than $\$ 24,999$ & 0.042 & 0.729 & $(-0.195,0.279)$ & 5.143 \\
\hline$\$ 25,000$ to $\$ 49,999$ & -0.014 & 0.816 & $(-0.132,0.104)$ & 2.457 \\
\hline$\$ 50,000$ to $\$ 74,999$ & -0.121 & 0.036 & $(-0.234,-0.008)$ & 2.301 \\
\hline$\$ 75,000$ to $\$ 99,000$ & -0.025 & 0.689 & $(-0.149,0.098)$ & 2.582 \\
\hline$\$ 100,000$ or more & 0.118 & - & - & - \\
\hline Retired & - & 0.427 & - & - \\
\hline No & -0.031 & 0.427 & $(-0.109,0.046)$ & 2.056 \\
\hline Yes & 0.031 & - & - & - \\
\hline Employed by Tourism & 一 & 0.153 & - & - \\
\hline No & -0.071 & 0.153 & $(-0.169,0.027)$ & 1.446 \\
\hline Yes & 0.071 & - & - & - \\
\hline Indirect Tourism Knowledge & -0.097 & 0.012 & $(-0.172,-0.022)$ & 1.299 \\
\hline Economic Tourism Knowledge & 0.588 & $>0.000$ & $(0.358,0.818)$ & 1.234 \\
\hline $\begin{array}{l}\text { Environmental Tourism } \\
\text { Knowledge }\end{array}$ & 0.509 & $>0.000$ & $(0.260,0.757)$ & 1.189 \\
\hline $\begin{array}{l}\text { Socio-cultural Tourism } \\
\text { Knowledge }\end{array}$ & -0.032 & 0.830 & $(-0.325,0.261)$ & 1.355 \\
\hline Community Attachment & 0.039 & 0.364 & $(-0.046,0.125)$ & 1.238 \\
\hline
\end{tabular}




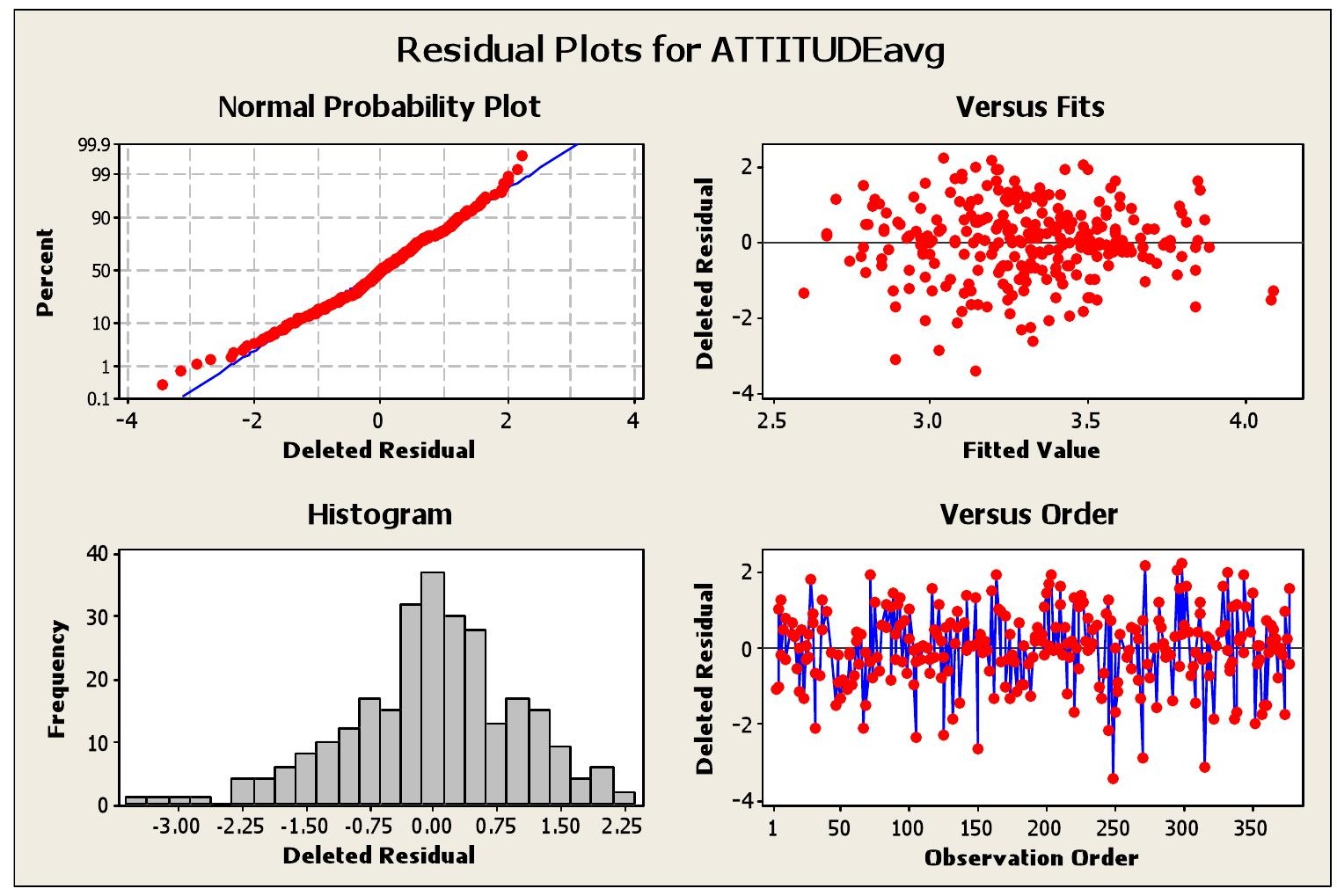

Figure 15: Residual plots for the general regression model

Economic knowledge and resident attitude toward tourism. Economic tourism knowledge was significantly associated with residents' attitudes toward tourism after adjusting for the effects of all other predictor variables ( $p$-value $<0.001$ ). An increase in direct economic tourism knowledge from zero to 100 percent was associated with an average increase in attitude toward tourism of 0.588 points on the 5-point Likert-type scale. With 95 percent confidence the actual increase in attitude toward tourism could be between 0.358 and 0.818 points.

Socio-cultural knowledge and resident attitude toward tourism. Socio-cultural tourism knowledge was not significantly associated with residents' attitudes toward tourism after adjusting for the effects of all other predictor variables ( $p$-value $=0.830$ ). 
Environmental knowledge and resident attitude toward tourism. Environmental tourism knowledge was significantly associated with residents' attitude toward tourism after adjusting for the effects of all other predictor variables ( $p$-value $<0.001$ ). An increase in direct environmental tourism knowledge from zero to 100 percent was associated with an increase in attitude toward tourism of 0.509 points on the 5-point Likert-type scale. With 95 percent confidence the actual increase in attitude toward tourism could be between 0.260 and 0.757 points.

Indirect tourism knowledge and resident attitude toward tourism. Indirect tourism knowledge was significantly associated with residents' attitude toward tourism after adjusting for the effect of all other predictor variables ( $\mathrm{p}$-value $=0.012$ ). An increase of one point in average indirect tourism knowledge on the 5-point Likert-type scale was associated to a decrease of 0.097 points on the 5-point Likert-type scale of residents' attitude toward tourism. These results suggest that if direct tourism knowledge is held constant subjects who had a higher level of perceived tourism knowledge were associated with slightly more negative attitudes toward tourism. As noted in research question one and two, higher direct knowledge of tourism is associated with more positive attitude. Community attachment and resident attitude toward tourism. Community attachment was not significantly associated residents' attitudes toward tourism after adjusting for the effect of all other predictor variables ( $p$-value $=0.364$ ).

Demographics and resident attitude toward tourism. After adjusting for the effects of all other variables, length of residency and interest in learning more about tourism were significantly associated to residents' attitudes toward tourism. An increase of ten years of residency in Morro Bay was associated with a decrease of 0.05 points on 
the 5-point Likert-type scale of residents' attitudes toward tourism. With a 95 percent confidence, the actual decrease in attitude toward tourism could be between 0.010 and 0.001 points per 10 years of residency.

Subjects interested in learning more about tourism were associated with a 0.152 point higher attitude score on the 5-point Likert-type scale of residents' attitudes toward tourism compared to subjects not interested in learning more about tourism. With 95 percent confidence, the gap in attitude scores between these groups could be between 0.036 and 0.27 points.

At the $5 \%$ significance level, the predictor variables level of education $(p=0.052)$ and household income $(\mathrm{p}=0.066)$ were not significantly associated with residents' attitude toward tourism after adjusting for the effects of all other predictor variables. However, when broken down into indicator variables for their individual categories, there was a moderate association detected in their indicator variables, "Completed high school or less" $(p=0.005)$ and "Household income between $\$ 50,000$ and $\$ 74,999 "(p=0.036)$. Subjects with a high school education or less were somewhat associated with an attitude toward tourism 0.264 point higher on the 5-point Likert-type scale compared to the average resident. With 95 percent confidence, the actual difference in attitude toward tourism could be between 0.079 and 0.448 points. Subjects with a household income between $\$ 50,000$ and $\$ 74,999$ were somewhat associated with a 0.121 point lower attitude toward tourism on the 5-point Likert-type scale compared to the average resident. With 95 percent confidence, the actual difference in attitude toward tourism could be between 0.008 and 0.234 points. However, these results for education and income should 
not be considered definitive because they were not statistically significant when considered together with the other categories of education and income.

Chapter five contains the study conclusions and implications. 


\section{CHAPTER 5}

\section{DISCUSSION}

The purpose of this study was to examine residents' attitudes toward tourism in Morro Bay, and to identify existing relationships among the predictor variables tested. The results of this study show that, residents of Morro Bay have slightly positive attitudes in general toward tourism. Residents' attitudes toward tourism were associated with length of residency, interest in learning more about tourism, subjective tourism knowledge, economic tourism knowledge, and environmental tourism knowledge.

\section{Conclusions}

Residents had a slightly positive overall attitude toward tourism in Morro Bay. This is a good sign for the Morro Bay's tourism industry, although there is still room to increase residents' positive attitudes toward tourism and strengthen the industry further. Based on residents' attitude toward tourism and the City of Morro Bay's plans to expand tourism promotion, it is believed that at the time of the study Morro Bay was in the apathy stage of Doxey's Irridex. Similarly, based on Morro Bay residents' attitude toward tourism, the well-defined tourists' market area, and tourism marketing efforts, it is believed that at the time of the study Morro Bay was in the development stage of Butler's tourism area cycle of evolution. Based on the stage of tourism development in Morro Bay, it is recommended that actions be taken to increase residents' awareness of tourism and increase positive attitudes toward tourism. This will help prevent Morro Bay from 
moving into the later stages of tourism development where more significant negative impacts occur to the community and residents' resent the tourism industry and tourists.

Previous research has identified several predictor variables as significant in examining residents' attitudes toward tourism. However, these predictor variables have not been significant in every study on residents' attitudes toward tourism. This may be attributed to the great variety of tourists' destinations and differences in host communities. All the predictor variables included in this study had been previously shown to be significant in examining residents' attitude toward tourism; however, in this study not all of the predictor variables were significantly associated with Morro Bay residents' attitudes toward tourism. The results of the socio-demographic variables in this study were consistent with the findings of Purdue et al. (1990) in that there were no associations in demographic variables other than length of residency.

Direct economic tourism knowledge had a significant impact on residents' attitude toward tourism, and had one of the greatest impacts on residents' attitudes toward tourism. The economic impact of tourism is among the most well recognized impacts of the tourism industry, and may have had an effect on the association with residents' attitudes toward tourism. The items measuring direct economic tourism knowledge were the most specific and narrow focused questions. This may have had an effect on residents' level of economic tourism knowledge. Perhaps if the economic tourism knowledge items were more general there may have been a higher overall level of economic tourism knowledge. Of the three questions used to measure direct economic tourism knowledge, the first economic question was the most general. Just over 40 percent of subjects selected the correct response to this item. The other two economic 
tourism knowledge items that were on specific economic impacts resulted in 21 percent and five percent (respectively) of subjects selecting the correct response. Due to the significant associations between direct economic tourism knowledge and residents' attitudes, it is recommended that it be used in efforts to increase positive attitudes toward tourism. The findings of this study on direct economic tourism knowledge are consistent with the findings of Andereck et al. (2005), Davis, et al. (1988), and Latkova (2008).

Direct environmental tourism knowledge also had a highly significant impact on residents' attitude toward tourism. The growing recognition of environmental tourism impacts, and the negative environmental impacts generated from the Morro Bay Power Plant may have had an impact on the association between residents' attitude toward tourism and environmental tourism knowledge. Direct environmental tourism knowledge had the highest mean score out of the three direct tourism knowledge categories tested. Environmental tourism knowledge should also be utilized in a social marketing effort to increase residents' positive attitude toward tourism.

Unlike economic tourism knowledge and environmental tourism knowledge, this study could not detect an association between socio-cultural tourism knowledge and residents' attitude toward tourism. A possible reason why socio-cultural tourism knowledge was not significantly associated with attitude could be due to poor understanding of socio-cultural tourism impacts. As a result there may be validity issues with the items measuring socio-cultural tourism impacts. A possible solution could be simplifying terminology used in the questions.

The predictor variables, interested in learning more about tourism, indirect tourism knowledge, and length of residency were statistically significant, but had smaller, 
impacts on residents' attitudes toward tourism. Of theses variables, indirect tourism knowledge had the most significant impact, which could be classified as moderate. When comparing the impact of direct and indirect tourism knowledge, this study supports that direct tourism knowledge is a better predictor variable for explaining residents' attitude toward tourism.

\section{Practitioner Implications}

Based on the results of this study, it is recommended that a social marketing campaign be implemented to increase residents' awareness and tourism knowledge. Such a campaign should focus on economic knowledge and environmental knowledge of tourism; socio-cultural tourism knowledge should also be promoted due to the significance of sustainable tourism, and the low level of understanding about its components.

The most common way residents said they would like to learn more about tourism was online. One way to offer additional tourism knowledge would be to create a website that is specifically designed for residents of Morro Bay. A website could be associated with the existing Morro Bay website (www.morrobay.org), similar to the websites created by the California Travel and Tourism Commission [CTTC]. The CTTC has create a website for the California tourism industry (www.tourism.visiticalifornia.com), that is associated with the primary California tourism site (www.visitcalifornia.com). Some possible components this site could include the following:

- The tourism industry's contribution to the local economy

- Public services that are partially funded by tourists spending 
- Ways tourism can be an environmentally friendly industry in Morro Bay

- Future plans for tourism in Morro Bay

- Ways the presence of tourism can affect the local cultural of the host community, such as the effects of tourism playing a more significant role in Morro Bay and the decreasing fishing industry.

Lankford and Howard (1994) stated, "Educational programs, public meetings, and workshops can be undertaken at the local level to help residents understand the tourism industry and its impacts" (p.135). This study has the same recommendation for Morro Bay. Sustainable tourism requires the involvement and support of all stakeholder groups. Therefore, it is suggested that the City of Morro Bay conducts a workshop to increase residents' knowledge and understanding of tourism, and have city officials, the tourism business improvement district group, the community promotions committee, local business owners, and residents in attendance.

\section{Theoretical Implications}

This study supported the use of direct tourism knowledge rather than indirect tourism knowledge as a predictor variable of resident attitudes. The majority of studies on residents' attitudes towards tourism have used indirect tourism knowledge, although this study offers evidence that direct tourism knowledge has a stronger association. This study also expanded direct tourism knowledge into the categories of economic, environmental, and socio-cultural. This study offered moderate support for separating these into different predictor variables. Although, socio-cultural tourism knowledge was not associated with residents' attitudes toward tourism, it is still recommended to be 
included due to its significance to sustainable tourism. Although, direct socio-cultural tourism knowledge was not significant in the model used for this study, it may be significant in other host communities.

A major strength of this study, was the response rate generated from the method of data collection. Online data collection has increased in popularity, although this study supports that there is still value in mailback questionnaires and door-to-door personal contact. This study increased the level of personalization and trust by delivering the questionnaires by hand, hand-addressing them, and hand-signing each cover letter. Another component believed to help achieve the high response rate was the use of $\mathrm{Cal}$ Poly branded letterhead. Morro Bay residents seemed to have positive attitudes toward Cal Poly and had an increased interest in participation upon learning of Cal Poly's involvement.

\section{Study Limitations}

The nature of survey research often fosters some study limitations that must be considered when evaluating study findings. This study was no exception and had some study limitations that should be addressed. One limitation of this study was that the sample only included residents that were homeowners. This sample method was used to exclude second homeowners and vacation rentals. The small portion of respondents with a household income of $\$ 24,999$ or less $(5.85 \%)$ may be due to the fact that the sample excluded residents in Morro Bay that rent.

Another limitation of this study was the items used to measure direct tourism knowledge. Previous research had not measured direct environmental or socio-cultural 
tourism knowledge, so previously validated questions could not be used. It would be beneficial for future research to check the validity and reliability of direct tourism knowledge questions.

Although the delivery method resulted in a high response rate, it may have caused a limitation. Questionnaire delivery times were not randomly selected throughout the week and the majority of the questionnaires were delivered in the later afternoon and on the weekends. Residents who were home during these times may have a higher probability of responding to the questionnaire and may have greater representation in this study.

\section{Future Research}

Future research on residents' attitude toward tourism should test the validity of direct economic, environmental, and socio-cultural tourism knowledge. This study supports the use of direct tourism knowledge as a predictor variable, although validated direct tourism knowledge questions would strength the support of its use in explaining residents' attitude toward tourism. In particular, direct socio-cultural tourism knowledge is believed to benefit from a study testing question validity because of questions raised in the inter-item reliability of the items used in this study.

Future research should also expand the measure of direct tourism knowledge by testing the effectiveness of methods to increase tourism knowledge. This study has suggested the use of public workshops and a website designed for the host community use. Future research should test the effectiveness of a public workshop as a method to increase residents' knowledge of the tourism industry. Effectiveness should be tested in 
the form of retained knowledge and public participation. Similarly, future research should also test the effectiveness of a website to increase residents' tourism knowledge. The effectiveness of the retained knowledge and site activity should be measured.

In summary, it is reasonable to assume direct tourism knowledge can be used to influence residents' attitude toward tourism. It is recommended that a social marketing campaign be conducted in Morro Bay to increase the level of tourism knowledge and increase support of tourism. Such a campaign would increase the strength of the tourism industry in Morro Bay, and would be a significant step in setting the foundation for sustainable tourism development. 


\section{REFERENCES}

Agarwal, S. (2002). Restructuring seaside tourism: The resort lifecycle. Annals Tourism Research, 29(1), 25-55.

Albuquerque, K. \& McElroy, J. (1999). Tourism and crime in the Caribbean. Annals of Tourism Research, 26(4), 968-984, PII: S0160-7383(99)00031-6

Allen, L. R., Long, P. T., Perdue, R. R., \& Kieselbach, S. (1988). The impact of tourism development on residents' perceptions of community life. Journal of Travel Research, 27(1), 16-21.

Andereck, K. L. \& Vogt, C. A. (2000). The relationship between residents' attitudes toward tourism and tourism development options. Journal of Travel Research, 39, 27-36.

Andereck, K.L., Valentine, K.M., Knopf, R.C., \& Vogt, C.A. (2005). Residents' perceptions of community tourism impacts. Annals of Tourism Research, 32(4), 1056-1076. doi:10.1016/j.annals.2005.03.001

Andreasen, A. R. (1994). Social marketing: Its definition and domain. Journal of Public Policy \& Marketing, 13(1), 108-114.

Andriotis, K., \& Vaughan, R. D. (2003). Urban residents' attitudes towards tourism development: The case of Crete. Journal of Travel Research, 42, 172-185.

Ap, J. (1992). Residents' perceptions on tourism impacts. Annals of Tourism Research, 19(4), 665-690.

Ap, J., \& Crompton, J. L. (1993). Residents'strategies for responding to tourism impacts. Journal of Travel Research, 32(1), 47-50 
Ap, J., \& Crompton, J. L. (1998). Developing and testing a tourism impact scale. Journal of Travel Research, 37(2), 121-130.

Babbie, E. (1998). The Practice of Social Research. Berkeley, CA: Wadsworth Publishing Company.

Bagozzi, R. P. (1975). Marketing as exchange. Journal of Marketing, 39, 32-39.

Bagozzi, R. P. (1979). Towards a formal theory of marketing. In Conceptual and Theoretical Developments in Marketing, O. C. Ferrell, S. W. Brown and C. W. Lamb, Jr. eds., 431-447. Chicago: American Marketing Association.

Belisle, F. J., \& Hoy, D. R. (1980) The perceived impact of tourism by residents: A case study in Santa Marta, Columbia. Annals of Tourism Research, 29(2), 303-319.

Berry, S., \& Ladkin, A. (1997). Sustainable tourism: A regional perspective. Tourism Management, 18(7), 433-440.

Blau, P. (1964). Exchange and Power. New York, NY: John Wiley

Brehm, J. M., Eisnehauer, B. W., \& Krannich, R. S. (2004). Dimensions of community attachment and their relationship to well-being in amenity-rich rural west. Rural Sociologoy, 69(3), 403-429.

Brougham, J. E., \& Butler, R. W. (1981). A segmentation analysis of resident attitudes to the social impact of tourism. Annals of Tourism Research, 8(4), 569-590.

Butler, R. W. (1980). The concept of a tourist area cycle of evolution: Implications for management of resources. Canadian Geographer, 24, 5-12.

Butler, R. W. (1996). Concept of carrying capacity: Dead or merely buried? Progress in Tourism and Hospitality Research, 2(3/4), 283-293.

Cavus, S., \& Tanrisevdi, A. (2003). Residents' attitudes toward tourism development: A 
case study in Kusadasi, Turkey. Tourism Analysis, 7, 259-269.

Choi, H. C. \& Sirakaya, E. (2005). Measuring residents' attitude toward sustainable tourism: Development of sustainable tourism attitude scale. Journal of Travel Research, 43, 380-394. doi:10.1177/0047287505274651

Choi, H. C. \& Sirakaya, E. (2006). Sustainability indicators for managing community tourism. Tourism Management, 27, 1274-1289. doi:10.1016/j.tourman.2005.05.018

Choi, H. C., \& Murray, I. (2010). Residents attitudes toward sustainable community tourism. Journal of Sustainable Tourism, 18(4), 575-594.

Coastal Alliance on Plant Expansion (July 1, 2009). Morro Bay Power Plant to be shut down in the next few years; a new plant cannot be built, ending the facility's 54year life. Retrieved from http://www.morrobaypowerplant.org/

Coastal Alliance on Plant Expansion (May 24, 2010). New State Ocean Water Restrictions Fail to Meet Federal Standards. Retrieved from http://www.morrobaypowerplant.org/

Davis, D., Allen, J., \& Cosenze, R. M. (1988) Segmenting local residents be their attitudes, interests, and opinions toward tourism. Journal of Travel Research, 27(2), 2-8.

Dillman, D. A. (1978). Mail and Telephone Surveys: The Total Design Method. Hoboken, NJ: John Wiley \& Sons, Inc.

Dillman, D. A. (2007) Mail and Internet Surveys: The Tailored Design Method (2nd ed.) Hoboken, NJ: John Wiley \& Sons, Inc.

Dinan, C. \& Sargeant, A. (2000) Social marketing and sustainable tourism: Is there a 
match. International Journal of Tourism Research, 2, 1-12.

Dogan, H. Z. (1989). Forms of adjustment: Sociocultural impacts of tourism. Annals of Tourism Research, 16, 216-236.

Doxey, G. (1975). A causation theory of visitor-resident irritants: Methodology and research inferences. In Sixth Annual Conference Proceeding of the Travel Research Association, 195-198. San Diego: Travel Research Association.

Emerson, R. M. (1972). Social exchange theory. Annual Review of Sociology, 2, 335-362

Fridgen, J. D. (1991). Dimensions of tourism. East Lansing, MI: Educational Institute of the American Hotel \& Motel Association.

Goeldner, C. R., and Ritchie, B. J. R. (2006a). Tourism: Principles, Practices, Philosophies (10th ed.). Hoboken, NJ: John Wiley \& Sons Inc.

Goeldner, C. R., and Ritchie, B. J. R. (2006b). Instructors Manuel to accommodate, Tourism: Principles, Practices, Philosophies $10^{\text {th }}$ ed. Hoboken, NJ: John Wiley \& Sons Inc.

Gunn, A. (2002). Tourism planning: Basics, concepts, cases. $4^{\text {th }}$ ed. New York: Routledge Taylor and Frances.

Gursoy, D., Jurowski, C., \& Uysal, M. (2002). Resident attitudes: A structural modeling approach. Annals of Tourism Research, 29, 79-105.

Gursoy, D., \& Rutherford, D.G. (2004). Host attitude toward tourism: An improved structural model. Annals of Tourism Research, 31, 495-516. doi:10.1016/j.annals.2003.08.008

Harrill, R., \& Potts, T. D. (2003). Tourism planning in historic districts: Attitudes toward 
tourism development in Charleston. Journal of the American Planning Association, 69(3), 233-244.

Henderson, J., and Quandt, R. (1971). Microeconomic Theory: A Mathematical Approach, $2^{\text {nd }}$ ed. New York: McGraw-Hill.

Homans, G. (1961). Social Behavior in Elementary Forms. New York: Harcourt, Brace \& World.

Houston, L. E., \& Gassenheimer, J. B. (1987). Marketing and exchange. Journal of Marketing, 51, 3-18.

Huh, C. \& Vogt, C. A. (2008). Changes in residents' attitudes toward tourism over time: A cohort analytical approach. Journal of Travel Research, 46, 446-455, doi: $10.1177 / 0047287507308327$

Inskeep, E. L. (1991). Tourism Planning: An Integrated and Sustainable Development Approach. New York: Van Nostrand Reinhold.

Iroegbu, H., \& Chen, J. S. (2001). Urban residents' reaction toward tourism development: Do subgroups exist?. Tourism Analysis, 6(2), 155-161.

Jacobs, D. (1974). Dependency and vulnerability: An exchange approach to the control of organizations. Administrative Science Quarterly, 19, 45-59

Jacobs, T. O. (1970). Leadership and Exchange in Formal Organizations. Alexandria, VA: Human Resources Research Organization.

Johnston, R. J., \& Tyrrell, T. J. (2005). A dynamic model of sustainable tourism. Journal of Travel Research, 44, 124-134. doi: 10.1177/0047287505278987

Jud, G. D. (1975). Tourism and crime in Mexico. Social Science Quarterly, 56(2), 324330 
Jurowski, C. A. (1998). A study of community sentiments in relation to attitudes toward tourism development. Tourism Analysis, 8, 17-34.

Jurowski, C. A., \& Gursoy D. (2004). Distance effects on residents' attitudes toward tourism. Annals of Tourism Research, 31(2), 296-312

Jurowski, C. A., Uysal, M., \& Williams, R. (1997). A theoretical analysis of hose community resident reactions to tourism. Journal of Travel Research, 34(2), 3-11.

Kayat, K. (2002). Power, social exchanges and tourism in Langkawi: Rethinking resident perceptions. The International Journal of Tourism Research, 4(3), 171-191.

Keogh, B. (1990) Public participation in community tourism planning. Annals of Tourism Research, 17, 449-465.

Kitnuntaviwat, V., \& Tang, J. C. S. (2008). Residents' attitudes, perception and support for sustainable tourism development. Tourism and Hospitality Planning \& Development, 5(1), 45-60.

Klupiec, C. (Producer). (2001). Impacts of tourism [DVD]. Broadway, NW: Insight Media.

Ko, D.-W., \& Stewart, W. P. (2002). A structural equation model of residents' attitudes for tourism development. Tourism Management, 23, 521-530.

Kotler, P. (1972). A generic concept of marketing. Journal of Marketing, 36, 46-54.

Kutner, M. H., Nachtsheim, C. J., \& Neter, J. (2004). Applied Linear Regression Models 4th ed. Boston: McGraw-Hill Irwin

Lankford, S. V., \& Howard, D. R. (1994). Developing a tourism impact attitude scale. Annals of Tourism Research, 21, 121-139.

Latkova, P. (2008). An examination of factors predicting residents' support for tourism 
development (Doctoral dissertation, Michigan State University).

Lawler, E. J., \& Bacharach, S. B. (1986). Power dependence in collective bargaining. In Advances in Industrial and Labor Relations, Vol. 3: 191-212. Greenwich, CT: JAI Press.

Levi-Strauss, C. (1969). The Elementary Structure of Kinship. Boston: Beacon Press. Lisa Wise Consulting (March 2008). Morro Bay and Port San Luis Commercial Fishers Business Plan.

Long P. T., Perdue, R. R., \& Allen, L. R. (1990). Rural resident tourism perceptions and attitudes by community level of tourism. Journal of Travel Research, 28(3), 3-9.

Madrigal, R. (1993). A tale of tourism in two cities. Annals of Tourism Research, 20(2), 336-353.

Mason, P., \& Cheyne, J. (2000) Residents' attitudes to proposed tourism development. Annals of Tourism Research, 22(1). 86-102.

McCool, S. F., \& Martin, S. R. (1994). Community attachment and attitudes toward tourism development. Journal of Travel Research, 32(3), 29-34

McGehee, N. G. \& Andereck, K. L. (2004). Factors predicting rural residents' support of tourism. Journal of Travel Research, 43, 131-140, doi: $10.1177 / 0047287504268234$

Meadows, H. D., Meadows, L. D., Randers, J., \& Behrens, W.W. (1972). The Limits to Growth: A Report for the Club of Rome's Project on the Predicament of Mankind (2nd ed.). New York: Universe Books.

Moschetti, G. J. (1979). The Christmas Potlatch: Refinement on sociological interpretation of gift exchange. Sociological Focus, 12, 1-7. 
Murphy, P. E. (1985). Tourism: A community approach. New York: Routledge.

Murphy, P. E., \& Price, G. G. (2005). Tourism and sustainable development. In W. F. Theobald (Eds.), Global Tourism. $3^{\text {rd }}$ ed. (pp. 167-193). Burlington, MA: Elsevier Inc.

Perdue, R. R., Long, P. T., \& Allen, L. R. (1987). Rural resident tourism perceptions and attitudes. Annals of Tourism Research, 14(3), 420-429.

Perdue, R. R., Long, P. T., \& Allen, L. R. (1990). Resident support for tourism development. Annals of Tourism Research, 17, 586-599.

Poitras, L., \& Getz, D. (2006). Sustainable wine tourism: The host community perspective. Journal of Sustainable Tourism, 14(5), 425-448.

Sharpley, R. (2000). Tourism and sustainable development exploring the theoretical divide. Journal of Sustainable Tourism, 8(1), 1-19.

Siegel, P. B, \& Jakus, P. M. (1995). Tourism as a sustainable rural development strategy: Building consensus in resident attitudes. Southern Journal of Rural Sociology, $11(1), 17-41$.

Sirakaya, E. Teye, V., \& Sönmez, S. F. (2002). Understanding residents'support for tourism development in the Central Region of Ghana. Journal of Travel Research, $41,57-67$

Snaith, T., \& Haley, A. (1994). In A. V. Seaton, C. L. Jenkins, R. C. Wood, P. U. C. Dieke, M. M. Bennett, L. R. Maclellan \& R. Smith, Tourism: The State of Art (pp. 826-835). New York: John Wiley \& Sons.

Swarbrooke, J. (1999). Sustainable Tourism Management. New York: CABI Publishing. 
Teye, V., Sönmez, S. F., \& Sirakaya, E. (2002). Residents' attitudes towards tourism development. Annals of Tourism Research, 29(3), 668-688.

Theobald, W. F. (Eds.). (2005). Global Tourism. $3^{\text {rd }}$ ed. Burlington, MA: Elsevier Inc.

Tomljenovic, R., \& Faulkner, B. (2000). Tourism and older residents in a sunbelt resort. Annals of Tourism Research, 27(1), 93-114

Um, S., \& Crompton, J. L. (1987). Measuring resident's attachment levels in a host community. Journal of Travel Research, 26(1), 27-29.

UN Department of Economic and Social Affaris: Department for Sustainable Development (n.d.) Core Publications: Agenda 21. Retrieved from http://www.un.org/esa/dsd/agenda21/index.shtml

Weaver, D. (2005). Sustainable Tourism. Burlington, MA: Butterworth-Heinemann

Wolcott, B. (2003, November). Recovery from an historic event. Progressive Engineer. Retrieved from http://www.progressiveengineer.com/PEWebBackissues2003/PEWeb\%2044\%20 Nov\%2003-2/Avila.htm

World Commission on Envirnonment and Development [WCED] (1987). Our Common Future. New York: Oxford University Press.

World Travel and Tourism Council. (2009). Travel and Tourism Economic Impact: Executive Summary. Retrieved from http://www.wttc.org/bin/pdf/temp/exec_summary_2009.html Models \& Theories/

Zimmermann, F. (1997). Future perspectives of tourism: Traditional versus new destinations in Oppermann, M. (ed) Pacific Rim Tourism p. 231-239 CAB International: Wallingford, CT. 
APPENDIX A: Residents' Attitudes Toward Tourism in Morro Bay Questionnaire 
Pg. 1

№. 0001

\section{A STUDY OF RESIDENTS' ATTITUDES TOWARD TOURISM IN MORRO BAY}

Circle the number that best describes your opinions regarding tourism in Morro Bay

IMPACTS ON THE STANDARD OF LIVING

Strongly Agree Neutral Disagree Strongly

Agree

Disagree

Tourism in my community has increased my own standard of living

Tourism development in my community will provide more jobs for local people

I have less money to spend as a result of tourism

I support tourism and would like to see it become the main industry in my community

The tourism industry will continue to play a major economic role in my community

The jobs tourism provides are not highly desirable jobs

$\begin{array}{lllll}5 & 4 & 3 & 2 & 1 \\ 5 & 4 & 3 & 2 & 1 \\ 5 & 4 & 3 & 2 & 1 \\ 5 & 4 & 3 & 2 & 1 \\ 5 & 4 & 3 & 2 & 1 \\ 5 & 4 & 3 & 2 & 1\end{array}$

\section{IMPACTS ON RECREATIONAL SERVICES \& FACILITIES}

Strongly Agree Neutral Disagree Strongly

Agree Disagree

Local recreation programs have expanded due to the influx of tourists to community

$\begin{array}{lllll}5 & 4 & 3 & 2 & 1 \\ 5 & 4 & 3 & 2 & 1 \\ 5 & 4 & 3 & 2 & 1 \\ 5 & 4 & 3 & 2 & 1\end{array}$

Tourism has reduced the quality of outdoor recreation opportunities in my community

More outdoor recreation development is desirable in my community

It is more important to provide recreation facilities for local people rather than tourists

APPROPRIATE AND SENSITIVE DEVELOPMENT ISSUES

Strongly Agree Neutral Disagree Strongly

Agree Disagree

I am against new tourism facilities that will attract

(n)

5

54

3

2

more tourists in my community

The noise level from the existing tourism facilities is not appropriate for my community

$\begin{array}{lllll}5 & 4 & 3 & 2 & 1\end{array}$


Pg. 2

My community should encourage more intensive development of tourist facilities

Shopping opportunities are better in my community as a result of tourism

Strongly Agree Neutral Disagree Strongly Agree Disagree

Tourism has negatively impacted the local environment

I believe tourism should be actively encouraged in my community

I believe tourism should be encouraged in the State of California

I support tourism as having a vital role in my community

The benefits of tourism to my community outweigh the negative consequences of tourism development

We should not try to attract more visitors

My community is growing too rapidly due to tourism

My community should become less of a tourist destination

$\begin{array}{lllll}5 & 4 & 3 & 2 & 1 \\ 5 & 4 & 3 & 2 & 1 \\ 5 & 4 & 3 & 2 & 1 \\ 5 & 4 & 3 & 2 & 1 \\ 5 & 4 & 3 & 2 & 1 \\ 5 & 4 & 3 & 2 & 1 \\ 5 & 4 & 3 & 2 & 1 \\ 5 & 4 & 3 & 2 & 1 \\ 5 & 4 & 3 & 2 & 1 \\ 5 & 4 & 3 & 2 & 1\end{array}$

\section{GOVERNMENT AND PUBLIC SERVICE ISSUES}

Strongly Agree Neutral Disagree Strongly

Agree

The quality of public service has improved due to

$\begin{array}{lllll}5 & 4 & 3 & 2 & 1\end{array}$
more tourism in my community

I would support local tax levies for tourism development

My community has better roads due to tourism

There is more litter in my community due to tourism

Tourism has increased crime in my community

The local government was right in approving the promotion of tourism to Morro Bay

City officials listen to residents about their concerns with tourism

$\begin{array}{lllll}5 & 4 & 3 & 2 & 1 \\ 5 & 4 & 3 & 2 & 1 \\ 5 & 4 & 3 & 2 & 1 \\ 5 & 4 & 3 & 2 & 1 \\ 5 & 4 & 3 & 2 & 1 \\ 5 & 4 & 3 & 2 & 1\end{array}$


Pg. 3

Strongly Agree Neutral Disagree Strongly Agree Disagree

I feel I cannot access the decision making process to influence

5

4

32

1

future tourism development in my community

Long-term planning by my city will not control the negative impacts of tourism on the environment

$\begin{array}{llllll}5 & 4 & 3 & 2 & 1\end{array}$

ABOUT TOURISTS IN YOUR COMMUNITY

Strongly Agree Neutral Disagree Strongly

Agree

Disagree

Tourists are valuable

$\begin{array}{lllll}5 & 4 & 3 & 2 & 1 \\ 5 & 4 & 3 & 2 & 1 \\ 5 & 4 & 3 & 2 & 1\end{array}$

Most residents like tourists in my community

\section{YOUR ATTACHEMENT TO MORRO BAY}

Strongly Agree Neutral Disagree Strongly

Agree

I feel there are a lot of coastal communities that could be a substitute for Morro Bay in which live

I have a lot of fond memories of past experiences with family and friends in Morro Bay

I have a strong emotional bond to Morro Bay

I feel a strong sense of belonging in Morro Bay

There are few satisfactory alternative communities to live in compared to Morro Bay

$\begin{array}{lllll}5 & 4 & 3 & 2 & 1 \\ 5 & 4 & 3 & 2 & 1 \\ 5 & 4 & 3 & 2 & 1 \\ 5 & 4 & 3 & 2 & 1 \\ 5 & 4 & 3 & 2 & 1\end{array}$

YOUR KNOWLEDGE ABOUT THE TOURISM INDUSTRY

Strongly Agree Neutral Disagree Strongly

Agree

Disagree

I have a high level of economic knowledge of the tourism

5

5

4

3

2

1

I have a high level of cultural knowledge of the tourism industry

5

5

I have a high level of environmental knowledge of the tourism industry

$\begin{array}{lllll}5 & 4 & 3 & 2 & 1\end{array}$

$\begin{array}{lllll}5 & 4 & 3 & 2 & 1\end{array}$


Pg. 4

\section{Please select one answer each for the next seven questions}

1. Which of the following is true of tourists spending?

a. Tourist spending is narrowly distributed within the local economy

b. Tourist spending is received mainly by hotels and restaurants

c. Tourist spending benefits mainly hospitality business suppliers

d. Tourist spending benefits all citizens in the community

e. Do not know

2. Which of the following is true in regards to tourism and the natural environment?

a. Tourism generally has a minimal impact on the local environment because tourists are experiencing the destination not extracting resources

b. Tourism can increase negative impacts on the local environment

c. Tourism only impacts the environment during peak seasons

d. None of the above

e. Do not know

3. How much did the tax collected on occupied hotel rooms in Morro Bay contribute to the general fund last year?

a. Less than $\$ 499,999$

b. $\$ 500,000-\$ 999,999$

c. $\$ 1,000,000-\$ 1,499,999$

d. More than $\$ 1,500,000$

e. Do not know

4. Tourism:

a. Can offer incentives for cultural development and preservation

b. Makes it virtually impossible to distinguish between destinations

c. Has little effect on local culture

d. Tends to dull people's appreciation of their cultural heritage

e. Has only a slight connection with culture

f. Do not know

5. The reproduction of cultural activities for tourists can have the following impact

a. Decrease the authenticity of cultural activities

b. Increase the authenticity of cultural activities

c. Will not have an impact on the authenticity of cultural activities

d. Cultural activities are not reproduced for tourists

e. Do not know

6. What is the tax rate on occupied hotel rooms that goes toward Morro Bay's general fund to pay for services such as the police and fire department?

a. $3 \%$

b. $5 \%$

c. $10 \%$

d. $15 \%$

e. Do not know 
Pg. 5

7. The tourism industry:

a. Does not have any serious environmental impacts

b. Has the potential to be an environmentally friendly industry

c. Will have just as many negative environmental impacts as most traditional industries

d. Is worse for the environment than traditional industries

e. Do not know

\section{For the next two questions select all answers that apply}

8. Out of the following, which can be affected by the presence of tourism for local residents? (Select all that apply)

a. Daily routines

b. Social lives

c. Beliefs

d. Values

e. None of the above

9. Tourism can offer what benefits to the local environment? (Select all that apply)

a. Can help raise awareness of environmental concerns

b. Can offer financial incentives to protect the natural environment

c. Can help decrease the amount of pollution

d. Tourism only negatively impacts the environment

e. None of the above

\section{NOW, ABOUT YOURSELF}

1. How would you describe your residence in Morro Bay? (please select one)

a. Full-time resident

b. Seasonal resident (vacation home)

c. I am not a resident of Morro Bay

2. How often do you speak with tourists visiting Morro Bay? (please select one)

a. Less than once a week

b. Once to twice a week

c. Three to four times a week

d. Five or more times a week

3. To what extent do you receive your income from the tourism industry? (please select one)

a. I am directly employed in the tourism industry

b. I am indirectly employed in the tourism industry (your work organization provides at least part of its products/services to tourism businesses)

c. I am not employed in the tourism industry at all

4. How many years have you lived in Morro Bay? years

5. Are you interest in learning more about the tourism industry in Morro Bay? Yes No 
Pg. 6

If yes, what kind of information would you want to learn more about, and how would you like to access the information?

6. Where in Morro Bay do you live? (please select one)

a. North of Highway 41 / Atascadero Rd

b. South of Highway 41 / Atascadero Rd

7. How many blocks from the nearest body of water (ocean or bay) do you live Blocks

8. How often do you visit the Embarcadero in Morro Bay? (please select one)

a. Less than once a week

b. Once to twice a week

c. Three to four times a week

d. Five or more times a week

9. What is your age? ___ years old

10. Are you: __ Male __ Female

11. What is your occupation?

12. Please indicate the highest level of education you have obtained. (please select one)I

a. Some high school

b. Completed high school

c. Some college

d. Completed 4 year college degree

e. Some graduate work

f. Completed graduate degree

13. Which statement best describes your total 2010 annual household income from all sources and before taxes? (please select one)

a. Less than $\$ 24,999$

b. $\$ 25,000-\$ 49,999$

c. $\$ 50,000$ - $\$ 74,999$

d. $\$ 75,000$ - $\$ 99,999$

e. $\$ 100,000$ or more

Thank you for your assistance! 
APPENDIX B: Cover Letter 
Dear Morro Bay Resident:

My name is Tyson Stockton and I am a graduate student in the Recreation, Parks, and Tourism Administration department at Cal Poly. I am writing to ask for your help in a study of residents' attitudes toward tourism in Morro Bay, CA. This study is part of an effort of the City of Morro Bay in conjunction with Cal Poly to gain a better understanding of residents' attitudes toward tourism in Morro Bay. This study will also be used to fulfill a thesis requirement for a Master of Science degree at Cal Poly.

You have been selected as part of a random sample of Morro Bay residents. We are asking those selected to complete the attached questionnaire about your opinions towards tourism in Morro Bay.

The results of this study will be used by the city of Morro Bay to better understand resident opinions toward tourism and help guide future development of the tourism industry. This is your opportunity to express your opinions about tourism and the role tourism should play in your community.

Your responses will be kept completely confidential and will be released only as summaries in which no individual's responses can be identified. When you return your completed questionnaire, your name will be deleted from the random sample and can never be connected to your answers in any way. Your participation in this study is voluntary. However, your by taking a few minutes to share your experiences and opinions about tourism in Morro Bay, you will be helping the City of Morro Bay make well informed decisions about tourism development. If for some reason, you prefer to not be included in this study, please let me know by returning the blank questionnaire in the enclosed stamped envelop.

As a token of our appreciation, your name will be entered into a drawing for a cash prize of $\$ 100.00$ when you return your completed questionnaire.

If you have any questions or comments about this study, or would like a copy of the completed project, I would be happy to speak with you. Feel free to give me a call at 707-217-5169, send an email to morrobaytourism@gmail.com, or send us a letter to the address above.

Thank you very much for helping with this important study.

Sincerely,

Tyson Stockton

M.S. Candidate

Cal Poly, San Luis Obispo

Recreation, Parks, \& Tourism Administration

San Luis Obispo, CA 93407 
APPENDIX C: Follow-up Cover Letter 


\section{Dear Morro Bay Resident:}

My name is Tyson Stockton and I am a graduate student in the Recreation, Parks, and Tourism Administration department at Cal Poly. About three weeks ago you received a questionnaire designed to assess your attitude toward tourism in Morro Bay. Your feedback is essential to ensuring that the results of the study are representative of the overall interests of the community. If you have lost or misplaced the previously delivered questionnaire, please complete the enclosed survey and return it in the postagepaid envelope provided. If you have already returned a completed questionnaire, please disregard this letter and thank you very much for participating.

Although we distributed questionnaires to other residents in Morro Bay, it is only by hearing from everyone in the sample that we can be sure that the results are truly representative of all Morro Bay residents.

The opinions of people who have already responded include a wide variety of opinions toward tourism, both positive and negative. The results will be very useful to the City of Morro Bay. To best serve the residents of Morro Bay, it is necessary for Morro Bay community leaders to know your opinions.

We understand that you may be concerned about your confidentiality. Protecting the confidentiality of people's answers is very important to us, as well as the University, and the City of Morro Bay. To help prevent your responses from being associated with your identity, a questionnaire identification number is printed on the front page of each questionnaire.

We hope that you will fill out and return the questionnaire soon. Once we receive your questionnaire you will be entered to win a cash prize of $\$ 100.00$. If for any reason you prefer not to respond, please let us know by returning a note or blank questionnaire in the enclosed stamped envelop.

Thank you for your help!

Sincerely,

Tyson Stockton

Cal Poly, San Luis Obispo

Recreation, Parks, \& Tourism Administration

San Luis Obispo, CA 93407

morrobaytourism@gmail.com 
APPENDIX D: Survey Administers Script and Potential Study Questions 
Hello my name is . I am a research assistant at Cal Poly. Cal Poly in conjunction with the City of Morro Bay is conducting a survey of residents' attitudes toward tourism.

You have been selected as part of a random sample of Morro Bay residents to express your views toward tourism in Morro Bay. As a small token of our appreciation when you return your completed questionnaire you will automatically be enter in a drawing for one cash prize of $\$ 100.00$.

Are you interested in participating?

If you would like, I would be happy to come back in 15-20 min to pick up the questionnaire.

Do you have any questions about the study?

Thank you for you're time and helping in this important study.

\section{Potential resident's questions}

1. What is the study for?

The results of this study will be used by the city of Morro Bay to better understand the opinions toward tourism and help guide the future development of the tourism industry. This is your opportunity to express your opinions on tourism and the role tourism should play in your community.

2. Will anyone know what my answers are?

Your responses will be completely confidential and only reported in summaries in which no individual's responses can be identified.

3. Ways to respond to the survey.

Pre-stamped envelope or come back and pick it up

4. How long will it take to complete?

Roughly $15 \mathrm{~min}$ 
APPENDIX E: Residuals Versus Predictor Variables 

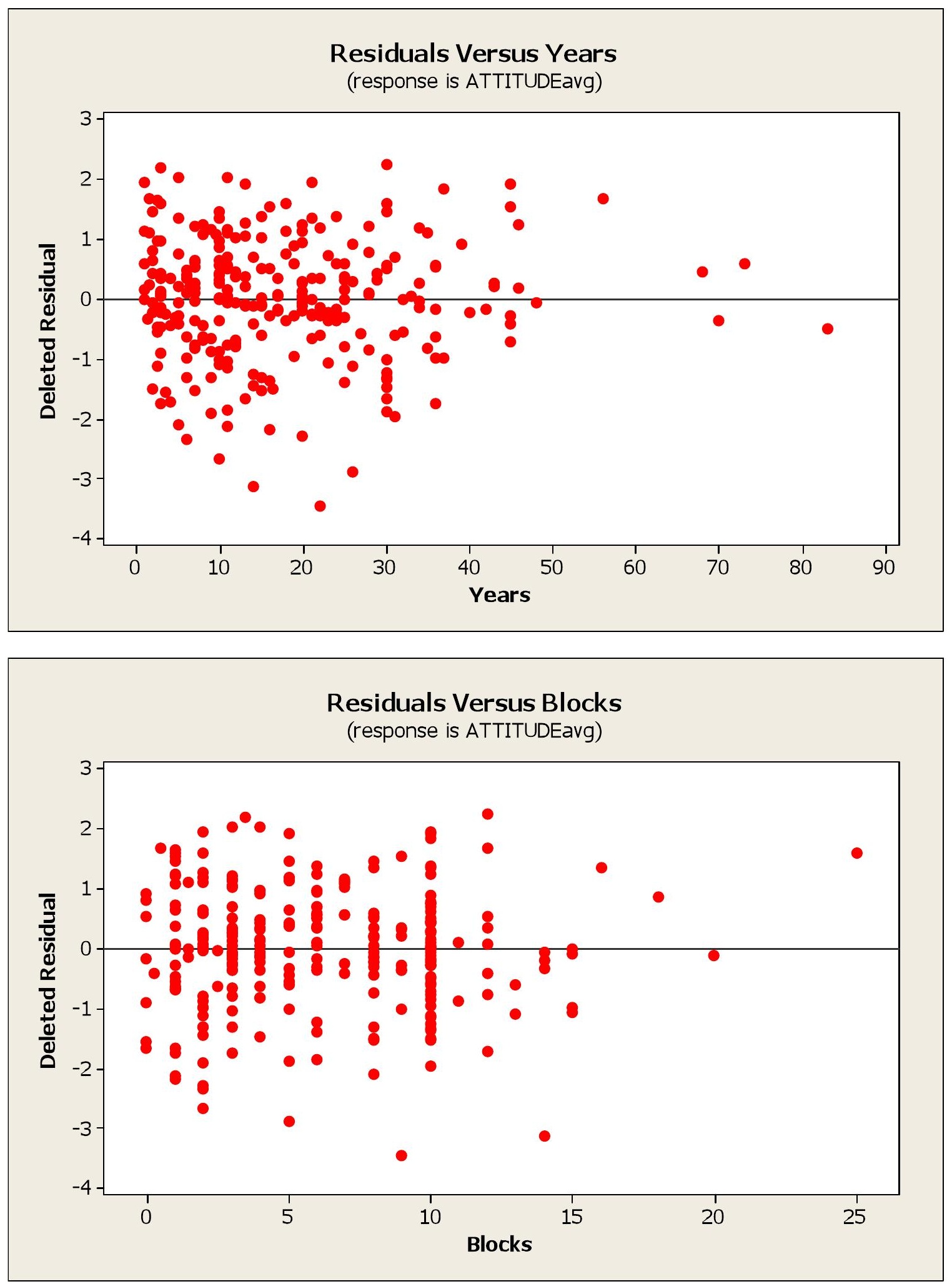

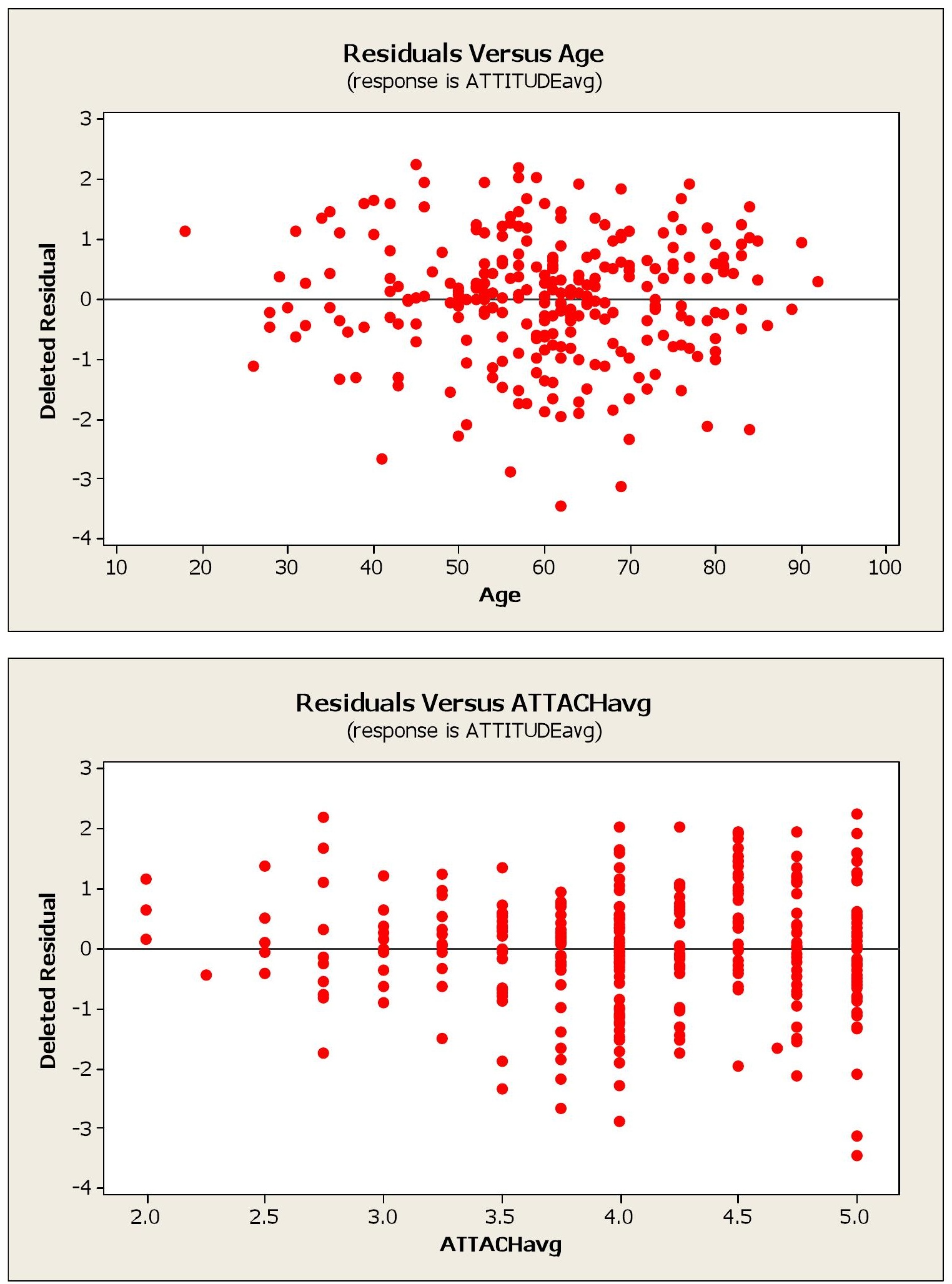

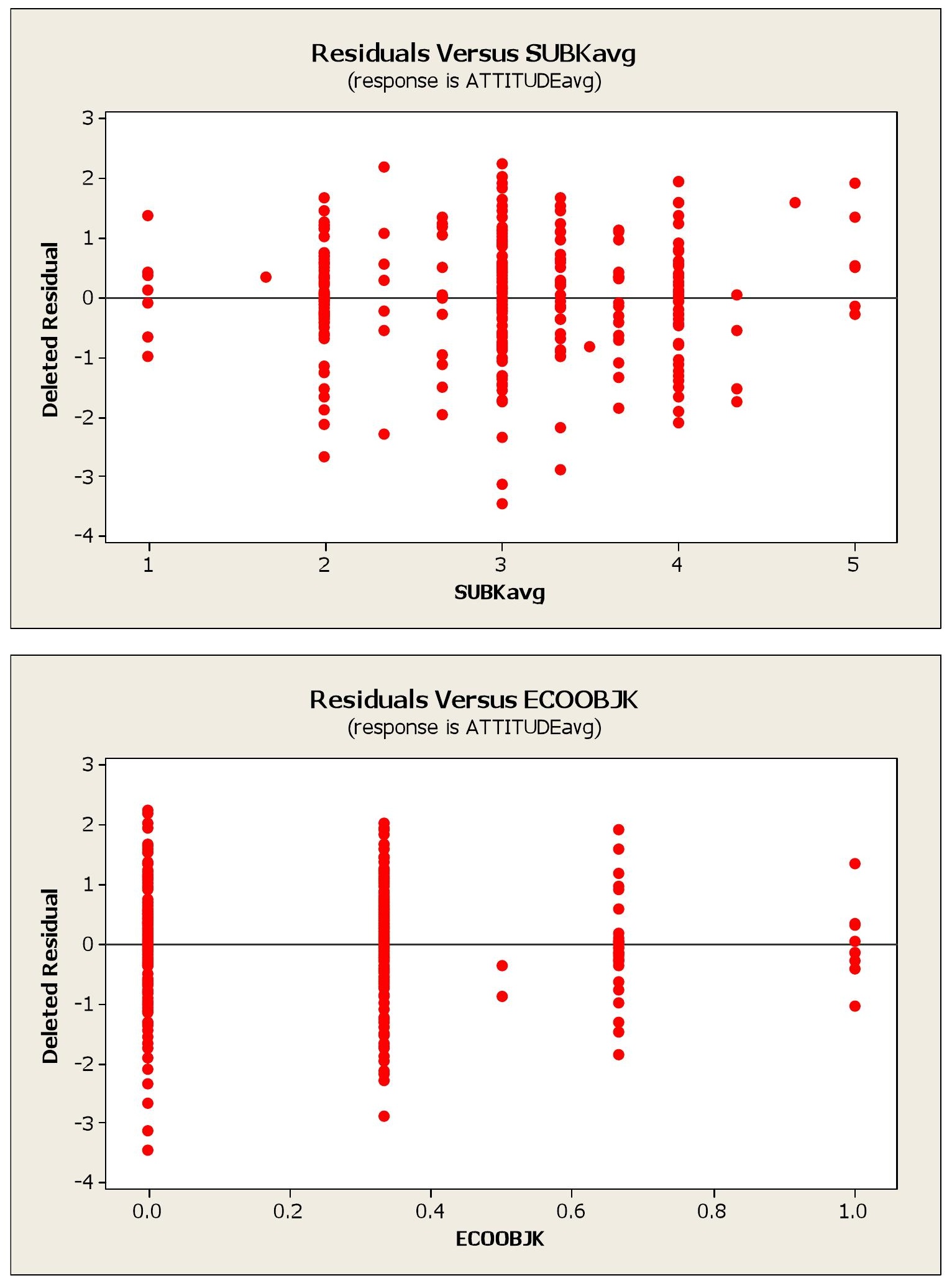

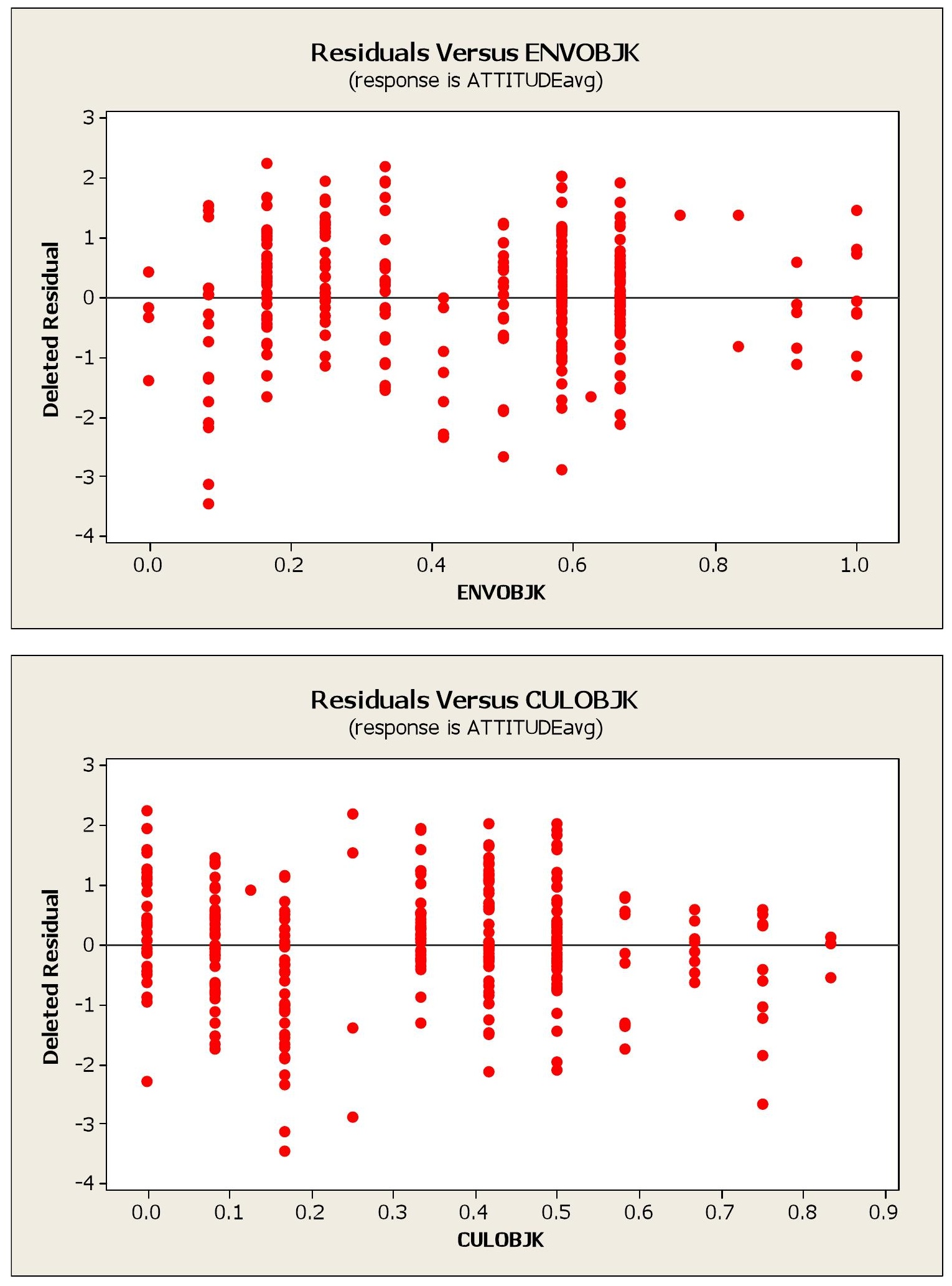